Historic, Archive Document

Do not assume content reflects current scientific knowledge, policies, or practices. 



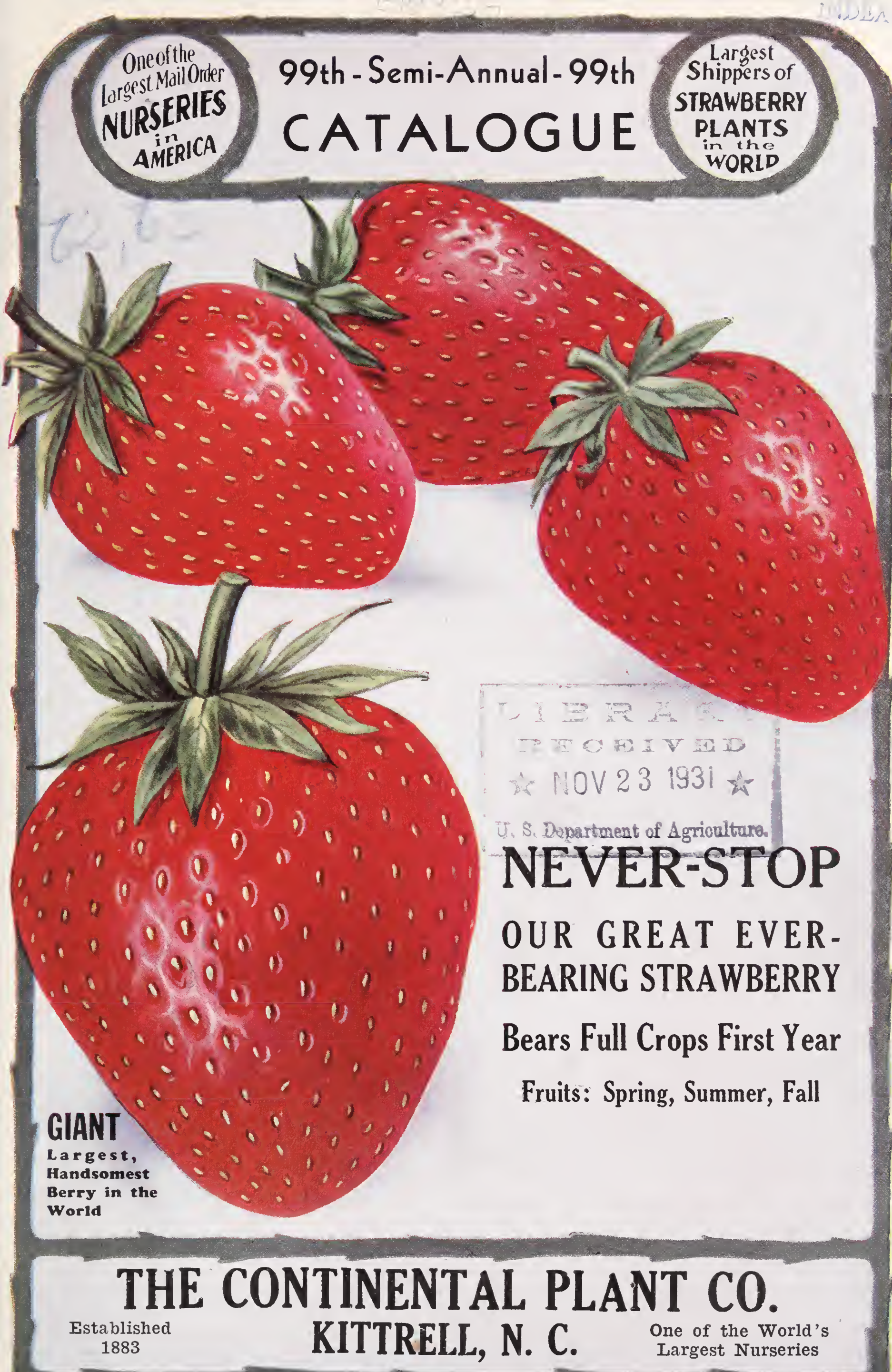


One of the Largest Nurseries in the World Selling Direct to the People

\section{9th Semi-Annual Catalogue of The Continental Plant Co.}

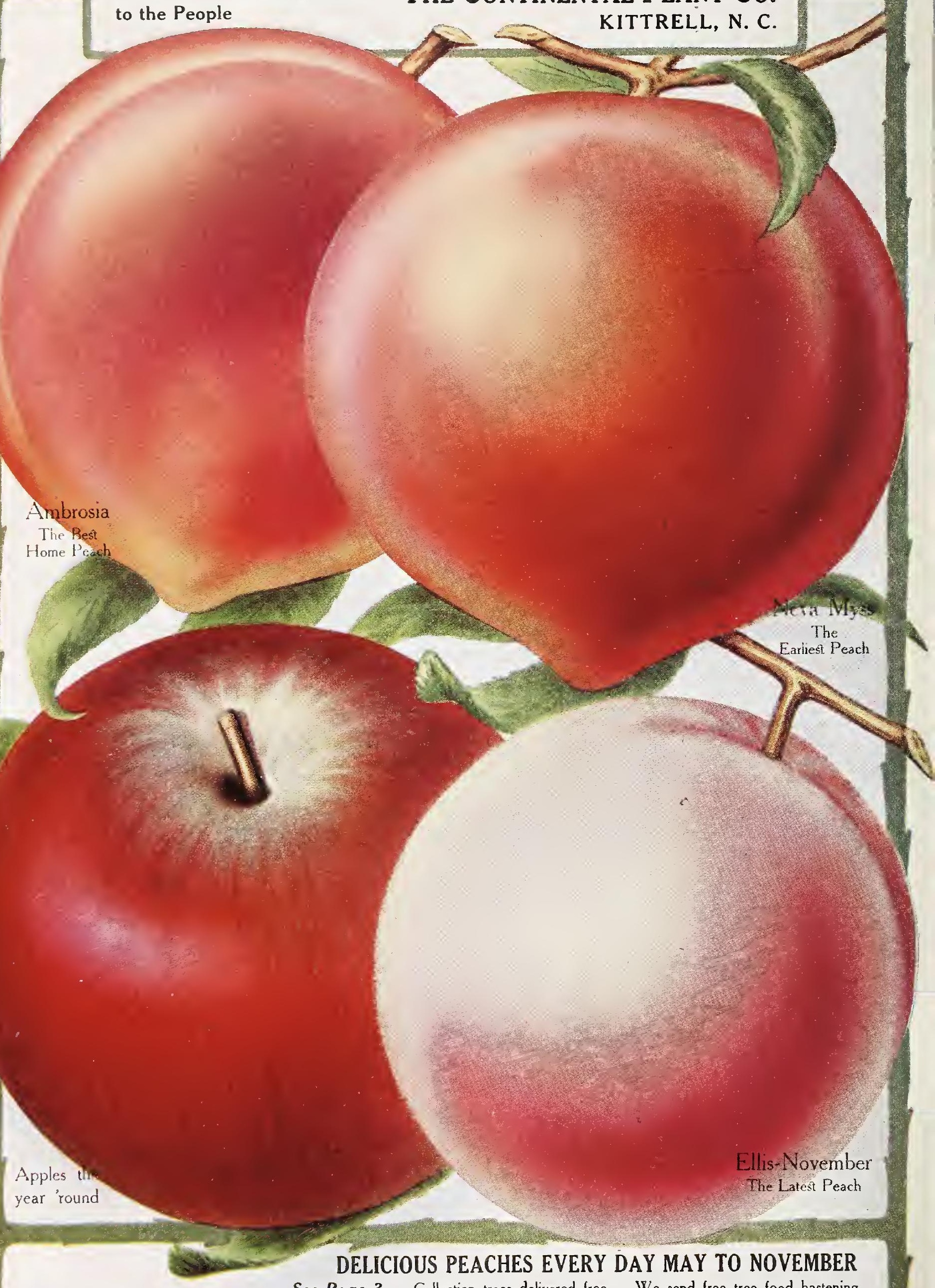

See Page 3. Collection trees delivered free. We send free tree food hastening growth and fruiting. also a book showing how to get quick and big results from fruit growing.

We Insure Every Tree to Live and Grow or Replace Same Free. (This refers to collections only.) AN INSURANCE POLICY WITH EVERY COLLECTION. See. Page 3. 


\section{AN INSURANCE POLICY}

We Deliver All WITH EVERY TREE AND PLANT

Collections $0 \mathrm{n}$ Pages 3, 4,5, $13,14,15$, 20,35 and 45 Free.

We insure all to live or replace absolutely free.

We can afford to because trees and plants grown in a natural nursery region like this are almost sure to live and grow off. We send free tree and plant-food, greatly hastening growth and fruiting. We send 100.page book, making success certain.
This Refers To Collections $0 \mathrm{n}$ Pages 3,4,5, $13,14,15$, 20,35 and 45 Only.

\section{NEVER-STOP}

\section{Genuine}

You don't have to wait. Full crop first year. Fruits spring, summer, fall. Absolute guarantee and bank reference. Most delicious of desserts. Big money-maker. Novelty of summer, fall and early winter Strawberries; catches customers wholesale. The exquisite flavor of Never-Stop, surpassing that of almost any other fruit in the world, holds them. So sweet, when fully ripe, it needs no sugar. A great saving. Thrives anywhere. See page 6 as to its success in fourteen states. Garden beds have paid at the rate of $\$ 7,500$ an acre.

\section{GIA N T}

Largest and Handsomest Strawberry Under the Sun, and one of the Best Spring Bearers.

Its tremendous size and blazing red color makes it a nine-days' wonder and sells it at high prices when other kinds go begging.

\section{Plants, Never Stop, value \$3 ? \\ 100 Plants, Giant, value

These 200 strictly select plants with Strawberry plant-food for both for one year, which doubles the crop, and 100-page "Modern Methods Fruit Book," worth $\$ 25$ to any general fruit grower, delivered free for $\$ 5.00$.

\section{MODERN METHODS GIVE YOU \\ Delicious Peaches Every Day NOVEMBER \\ (June to October)}

\section{Plant Peach Trees You Don't Have to Wait}

1 select tree of NEVA-MYSS. Earliest of all peaches, has never failed to bear. May

1 select tree of SNEED. So luscious you can drink it like an orange. Early June

1 select tree of GREENSBORO. One of the handsomest of peaches. Mid-June

1 select tree of AMBROSIA. Soft and delicious. Early July.

1 select tree of BELLE OF GEORGIA. Famous for size, flavor and beauty. Mid-July

1 select tree of ELBERTA. Most delicious of Peaches. Late July..

1 select tree of NIAGARA. Soft and delicious. Early August.

1 select tree of WINE. A luscious drinkable Peach. Mid-August..

1 select tree of FOUR-IN-ONE. Largest of all Peaches. Mid and late August

1 select tree of EATON'S GOLD. Fine for eating; best for preserving. Early to Mid-September

lect tree of WHITE HEATH. Fine for eating or preserving. Late Sep-

tember and October

1 select tree of ALBRIGHT'S OCTOBER. Fine for eating or preserving. Mid-October to November

\section{All Trees in This Collection Guaranteed to Live}

Above collection (12 select trees), fruit tree food, hastening growth and fruiting, and 100-page "Modern Methods Fruit Book," delivered free, cash with order for

See pages $4,5,13,14,15,20,35$, and 45 for collections of Apples, Pears, Raspberries, Roses, etc., delivered free with "Quick' Fruit" fruit tree food and book.

We never send Fruit Bciok unless it is asked for. Thousands of our customers already have it. See page 50 for index telling you where to find anything. 


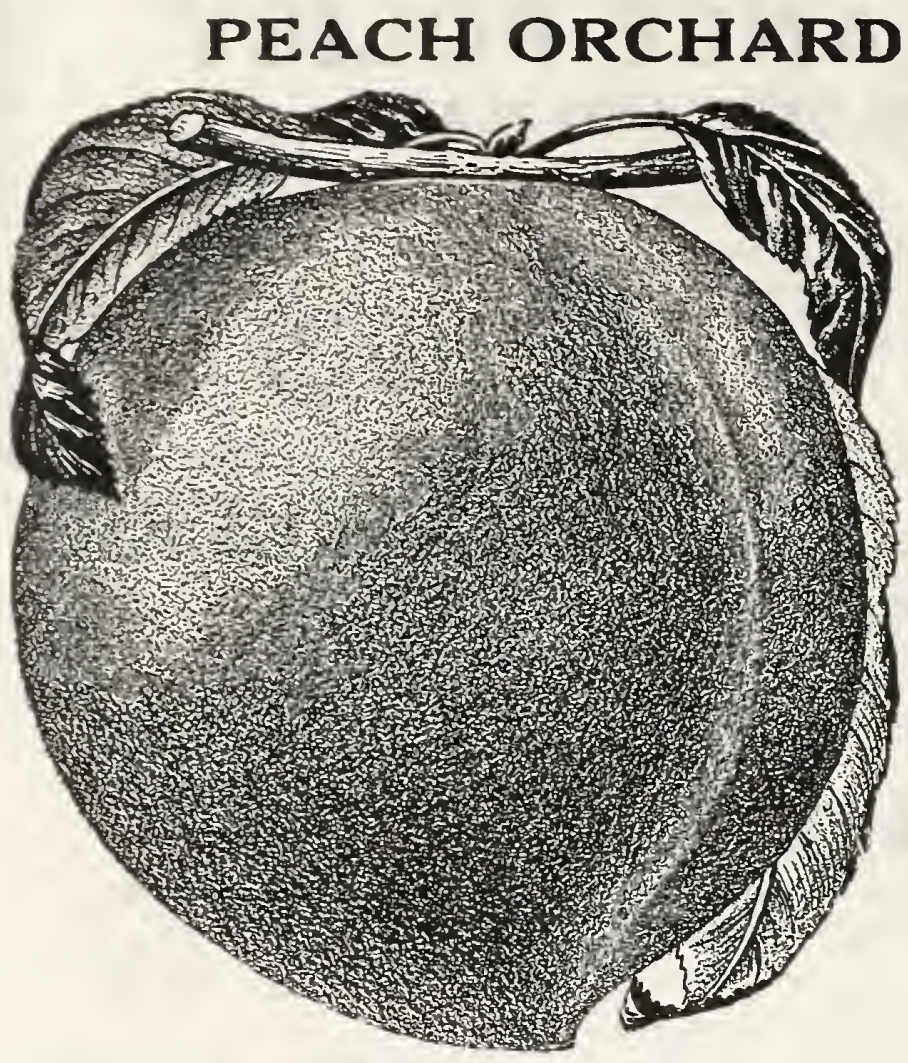

FOR \$10.00

Delicious Peaches Every Day from May to November (June to October in the North)

This collection will plant onefourth an acre and commence bearing in two years. Will supply all the peaches you need for cunning, preserving, etc., and give you a large surplus, which can be easily sold for fancy prices. Just let it be known that you have nice peaches and people will come to your orchard and buy all you have and want more. We have custcmers making big money on small family peach orchards.

Trees in this collection are the very pick of our immense stock, so perfectly balanced in root and branch growth that they will grow fast and come quickly into bearing. They are put into perfect shape before leaving us by being pruned root and branch precisely right, saving you all doubt and trouble in that respect. They are packed with extra care so as to arrive as fresh as when dug. With each collection is sent enough strongly concentrated (highly ammoniated) Modern Method Fruit Tree-Food to push the trees into quick growth and fruiting. This food, combined with their superior vigor, brings them into bearing at two years old, a year younger than ordinary trees.

We also send our 100 -page book, worth $\$ 25$ to any fruit-grower because it not only tells, but shows, by clear practical cuts, how to plant, prune, manure, and cultivate all kinds of fruit. Page 12 tells also about the book and fruit tree-food. See page 3 for collection of Peaches selected for their delicious flavor, ripening without a break from May to November.

\section{EVERY TREE IN THIS COLLECTION IS INSURED TO LIVE OR WE} REPLACE ABSOLUTELY FREE

2 Select Trees NEVA-MYSS. Earliest of all peaches, has never failed to

2 Select Trees SNEED. So luscious you can drink it like an orange. Early June

2 Select Trees GREENSBORO. One of the handsomest peaches. Mid-June.

2 Select Trees CARMAN. Soft and delicious. Early July.

2 Select Trees BELLE OF GEORGIA. Famous for size, flavor and beauty. Mid-July

2 Select Trees ELBERTA. Most delicious of Peaches. Late July

2 Select Trees AMBROSIA. The most exquisitely delicious Peach. Early July

2 Select Trees NIAGARA. Soft and delicious. Early August.

2 Select Trees WINE. A luscious drinkable peach. Mid-August

2 Select Trees FOUR-IN-ONE. Largest of all Peaches. Mid and late August

2 Select Trees EATON'S GOLD. Fine for eating; best for preserving. Early to Mid-September

2 Select Trees WHITE HEATH. Fine for eating or preserving. Late September and October

2 Select Trees ALBRIGHT'S OCTOBER. Fine for eating or preserving. Mid-October to November

1 Select Tree ELLIS NOVEMBER. A real November Peach.

Above collection (27 select trees), fruit tree food, hastening growth and fruiting, and 100-page "Modern Methods Fruit Book" delivered free, cash with order, for...

WE RESERVE THE RIGHT TO SUBSTITUTE OTHER VARIETIES IN COLLECTIONS ON PAGES 3, 4, 5, 13,14,15, 20,35, and 45, IF IT IS NECESSARY. We are forced to do this to protect ourselves, but of course we only substitute a variety of equal value, and which ripens its fruit at the same time as the tree or plant for which it was substituted. These collections have found such a ready sale that we are sometimes unable to supply as many trees of one or two of the varieties as we need. 


\section{Choice Select Fruit Trees for the Home Orchard}

All trees in the following selections delivered free with quick fruit tree food to hasten growth and fruiting and our Modern Methods Book, covering fruit growing from $A$ to $Z$. Every tree guaranteed to live and grow off or replaced free of charge.

\section{Apple Trees}

Varieties That Circle the Season Like the Sun

1 Early Colton, ripens in May and June. $\$ .60$

1 Yellow Transparent, ripens in late June

1 Summer Ambrosia, ripens in July and August......................................................................... $\quad .60$

2 Magnum Bonum, ripens in September and October............................................................... $\quad .90$

2 Fall Ambrosia, ripens in October and November (and keeps all winter)......... 1.20

2 Winesap, ripens in October and November (and keeps all winter) ......................... $\quad .90$

2 Stayman Winesap, ripens in October and November (and keeps all winter) $\quad .90$

1 Mammoth Black Twig, ripens in October and November (and keeps all winter)

Regular price $\$ 6.00$

12 TREES, delivered free with fruit tree food and book (cash with order) . $\$ 6.00$

\section{Pear Trees}

Giving You This Delicious Fruit the Season Round

2 Early Harvest. Delicious pink-cheeked Pear (June) $\$ 1.50$

1 Koonce. Large, luscious Pear (July).

2 Bartlett. Famous for fine flavor (August) ....................................................................................... 1.50

2 LeConte. A superb Pear (September) ……........................................................................... 1.50

2 Kieffer. Best keeping of all Pears and good eating when mellow........................... 1.50

Regular Price

ALL 9 TREES, delivered free with fruit tree food and book (cash with order) $\$ 6.50$

\section{Trees-Pear and Plum}

The Cream of Varieties

1 tree Early Harvest Pear.................... $\$ .75 \mid 2$ trees Keiffer Pear.

1 tree Bartlett Pear $\quad .75 \mid 2$ trees Red June Plum

1 tree LeConte Pear...................................... $.75 / 2$ trees Abundance Plum............................. 1.50

Regular price

ALL 9 TREES, delivered free with fruit tree food and book (cash with order) $\$ 6.50$

A Really Prolific and Ever-Bearing Raspberry

Bears Good Crop First Year and Fruits May to September

24 Plants Everbearing Raspberries.

100 Giant Spring Bearing Strawberries 


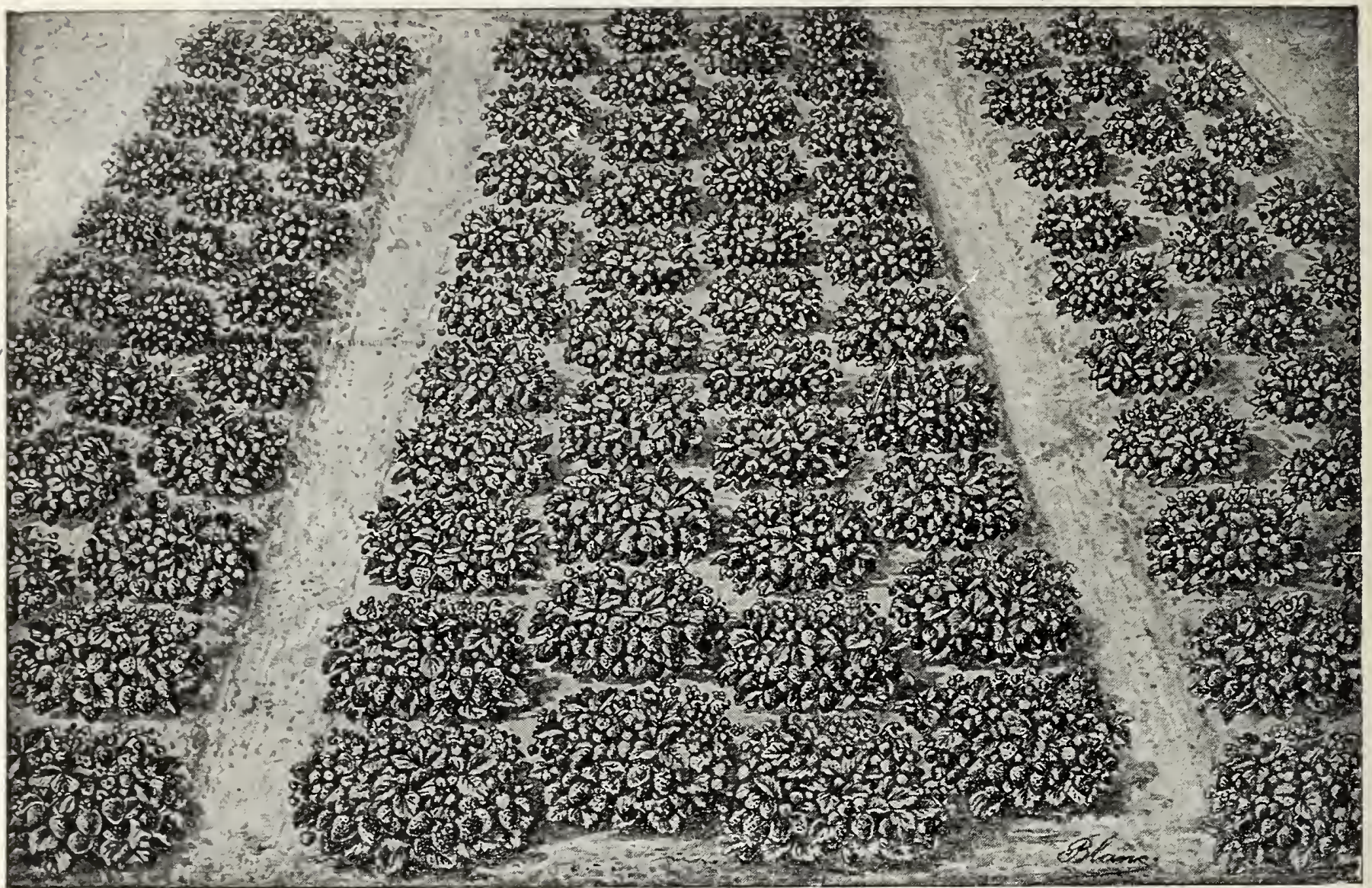

SEE WHAT HAS BEEN DONE ON A PATCH THE SIZE OF A VERY SMALL ROOM 100 plants have yielded $\$ 25$ worth of Never-Stop Berries (100 quarts at 25 cts.), in a bed $12 \times 12$ feet, size of a very small room, or at the rate of $\$ 7.500$ per acre.

\section{SPLENDID SUCCESS OF NEVER-STOP}

\section{Selected from the Thousands of Testimonials We Get}

District of Columbia-The Never-Stop Strawberry plants you sent a year ago last fall have proven a good variety and am pleased with the plants. Had 80 plants and between July and November picked 40 quarts of berries and they have already started to bud and bloom this spring. Grant $B$. Bruce, Washington, D. C.

Pennsylvania-From the 16 -foot square (100 plants) I have sold since July 20th $\$ 12.50$ worth Never-Stop Strawberries. A. W. Bell, Pa.

Illinois-A few years ago we had 300 of your Never Stop Strawberries and they were certainly fine. Picked half a gallon of berries on December 14 th, so want to start another bed. We lived at Minia, Ill., then. G. W. Brooks, Atlanta, Ill. Feb. 10, 1931 .

Kentucky-Referring to the 200 Never-Stop Strawberries I ordered from you this spring. They are bearing fine. This is the first crop they have had and are fine. Mrs. $R$. ' $T$ ' Marks, Kentucky. July 18, 1928.

Tennessee-I got some Never-Stop Straw berry plants from you a few years ago and they did so well. Bore for two or three months. Fruit trees 1 ordered from you 10 or 12 years ago are doing tine. Mrs. U. A. Newborn, Tenn. Jan., 1929.

Missouri-I wish to say the Never-stop Strawberries are wonderful. Never saw anything to beat them. They are very fine and abundant bearers and many grew to be $1 \frac{1}{2}$ inches through. My Giant you sent me were strong vines and large berries. W. 'T. Wilkerson, Mexico, Mo.

Kansas-Had plants from New Jersey, Michi. gan and Iowa but your Never-Stop outgrew all and bore fine berries till freezing weather. Dr. H. T. Johnson, Cottonwood k'alls, Kans.
New Mexico-After four years test have decided to cut out all other kinds. Intend to make growing of the berry my business, establishing farms in different parts of the country. It must have a big future. W. $H$. Ried, Las Crecus, New Mexico.

Arkansas-As to Never-Stop Strawberries, they met every expectation. The only thing is to keep them from bearing themselves to death. They are indeed a mystery in the berry family. W. S. Ellis, Jonesboro, Ark.

Ohio-A number of years ago I bought some of your Everbearing Strawberries (and they are) and as I have bought another country home, I wish you to send me your latest catalogue and price list of all of your goods, for I will need a lot of stuti to tix up this place. J. G. Ray, Barberton, Ohio.

Georgia-Last spring I bought 100 NeverStop Strawberry plants from you. Several of my friends are so pleased with them that they may be purchasers of plants the coming fall. F. B. Chandler, Georgia. August 15, 1928.

Maryland-The Never-Stop Strawberry plants gotten from you last December are fruiting fine now. Edgar E. Harry, Catonsville, Md. Sept. 24, 1929 .

North Carolina - I am going to order some Everbearing Strawberry Plants from you soon. I had some lovely berries from you years ago. The plants bore all the year, and Thanksgiving I had lovely strawberries. I am $\mathrm{so}^{\circ}$ anxious to get the same kind and try again. Mrs. Wm. P. Mercer, Rocky Mount, N. C. January 28, 1931.

Mississippi-I have had your Never-Stop before and let the weeds choke them. 'I'his time we hope to do better as we have never been able to buy strawberries off the market to suit us since eating the Never-Stop. Mrs. H. J. Burnham, Jackson, Miss. Mch. 4, 1930. 


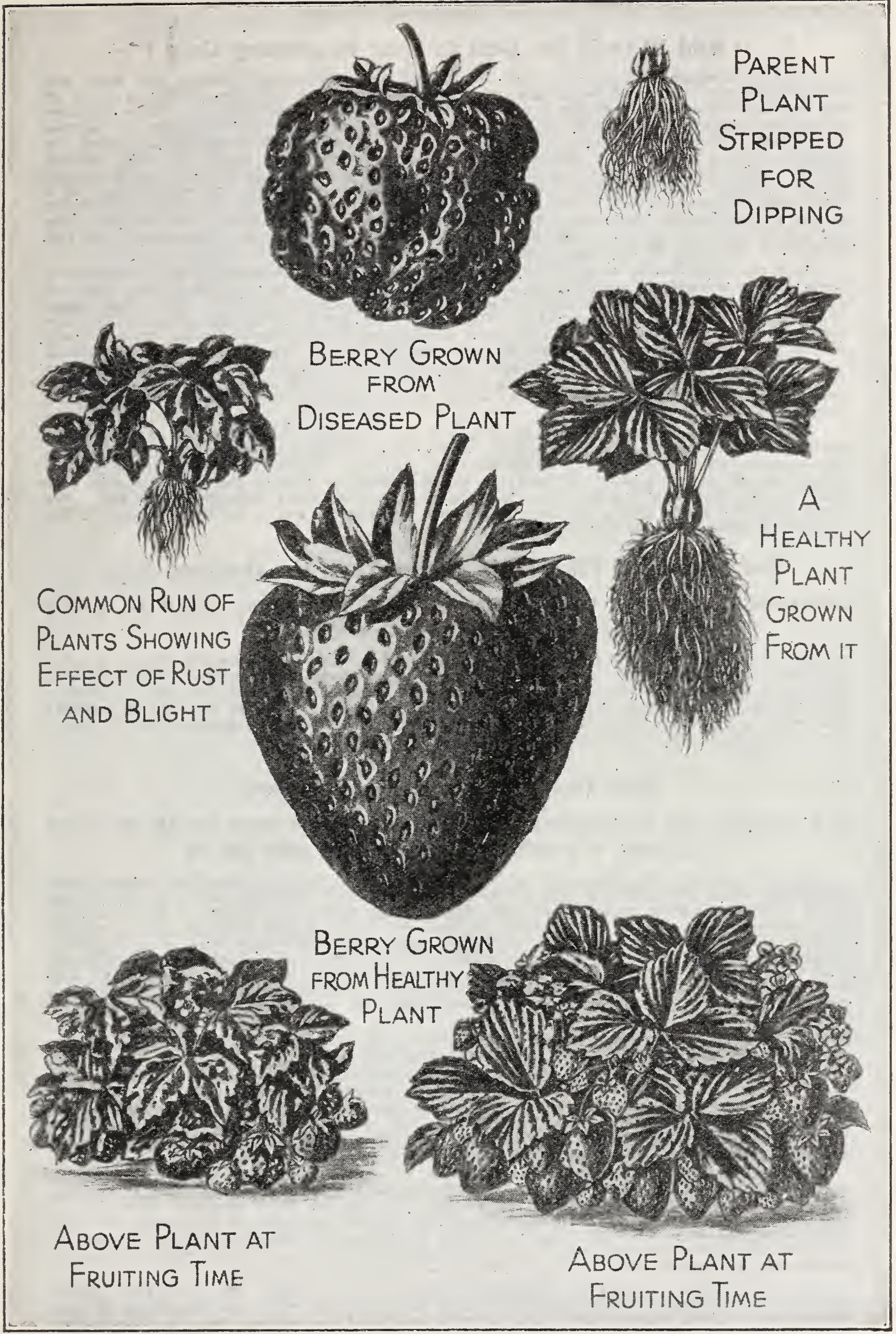




\section{Add 10 to 50 Per Cent to Your Strawberry Crop}

It is an undisputed fact that rust, blight, and obscure fungous diseases cut down the Strawberry crop of the whole country from 10 even up to 50 per cent, if the weather of the fruiting season is exceedingly favorable for the spread of these diseases. These diseases cover the country like the dew, no matter how loudly some sections may claim to be free from them. While they do some harm in killing the leaves and checking growth during the summer, it is at fruiting-time that the great damage is done. They attack the long, delicate stem on which the fruit grows, sap its vigor, and lessen the size of the berry, often deforming it and making it knotty. This is the chief reason that Strawberries run smaller and of a poor shape toward the end of the season. By that time disease has got in full possession of the infected plant. Of course, the difference shown in the illustration on the preceding page is an extreme case, but, except in exceedingly rare seasons, the disease is there and it tells on the profit all the way from 10 per cent up.

Only the most heroic remedy that goes right down to the bedrock of the trouble will destroy disease as deep seated as this. We strip all parent plants down to the bud and plunge them head and ears in strong fungicide before planting. This destroys every germ of disease. The plants are then set on fresh land. The result is that plants grown in these felds are absolutely free from rust and blight, and that no matter how prevalent these diseuses are in your neighborhood your fields set with our plants will not suffer to any appreciable extent the first two years, no matter how unfavorable the weather may be for the plant or favorable for the disease. You will get a larger and finer crop of berries with a much smaller proportion of small and knotty berries, which always ruin the late pickings from diseased plants.

The parent plants, after the above treatment, are not allowed to weaken themselves by fruiting. All blooms are kept off and the whole vigor of the plant thrown into making the young plants which are sold to our customers for planting. This is believed to throw greater vigor into the young plants. It certainly has the effect of making young plants take root early in the season, and gives them full time to complete their root-growth by fall. We never strip the young plants we sell; they would not ship as well. We leave enough of the old growth around the bud to protect it.

\section{Our Trees and Plants Are Better Than the Common Run}

\section{BECAUSE THEY ARE GROWN BY MODERN METHODS, THAT IS, EACH IN ITS NATURAI SOIL}

The success of everything depends upon the start it gets and especially is this true of the fruit tree and plant, for there are more points essential to the highest success with fruit trees than anything else in the world. Trees and plants instead of loafing must get right down to business and come into bearing young. Of the fruit there mnst not only be quantity but, what is nowadays even more important, quality. And quality embraces many thingssize, color, shape, flavor, firmness, keeping qualities, etc.

\section{How Can We Give the Right Start?}

\section{WE CANNOT DO IT OURSELVES. ALL THAT WE CAN DO IS TO GIVE NATURE A FREE HAND AND IET HER DO IT}

We have to start the young tree in its natural soil-in the kind of soil in which nature started it when she called it into being-created it. Now probably nowhere else in the world is there as great a variety of soils right side by side as in the North Carolina hills. Our twelve nursery farms extend right through the heart of this natural nursery region. Side by side we have the stiff soil in which the young peach tree must start to be free from borers and other enemies; the well-drained loam on which the young apple tree is freest from knot and gall; the gravelly hill for the young cherry tree in the pockets between the hills the deep, peaty loam for the pear; and in others the alluvial soil-mixture of sand and humus - for the hedge plant, reproducing identically its habitat on the Amoor River in Siberia.

We have at command an almost unlimited quantity of fresh land which enables us to grow all trees and plants on clean, uncontaminated soil.

Then we are situated in the country at an average altitude in an average climate. Uur growing season is long, enabling trees and plants to mature thoroughly.

Our open winters enable us to ship trees and plants dug right fresh from the ground instead of the stale, cellared stock often sold. The result is that trees and plants grown here are acclimated - that is, at home over the whole country-north, south, east and westand are surer to live and succeed than if they did not have this advantage.

We do not mean that other nurserymen are ignorant of the forementioned soil advan. tages and that they do not avail themselves of them as far as possible; but few, if any, are so favorably situated in that respect as we are. Nor do we claim that the start we give trees will do it all. It gives a substantial advantage more than equal to the cost of the trees and plants, but it is only one step in Modern Methods. For the best results, it must be followed by Modern Methods in planting, in pruning, in manuring, and in cultivating, all of which are explained by the story and plain cuts in our 100-page book.

All that we ask is that you compare our trees with the common run. The huge, gawky size of common trees is a mere matter of heavy manuring, and when not backed up by ront growth is a positive disadvantage. But note the wealth of rocts of our trees and the perfect balance between root and tree, and the general business-like look of the whole combination. We destroy all over-size trees as carefully as all under-sized ones. 


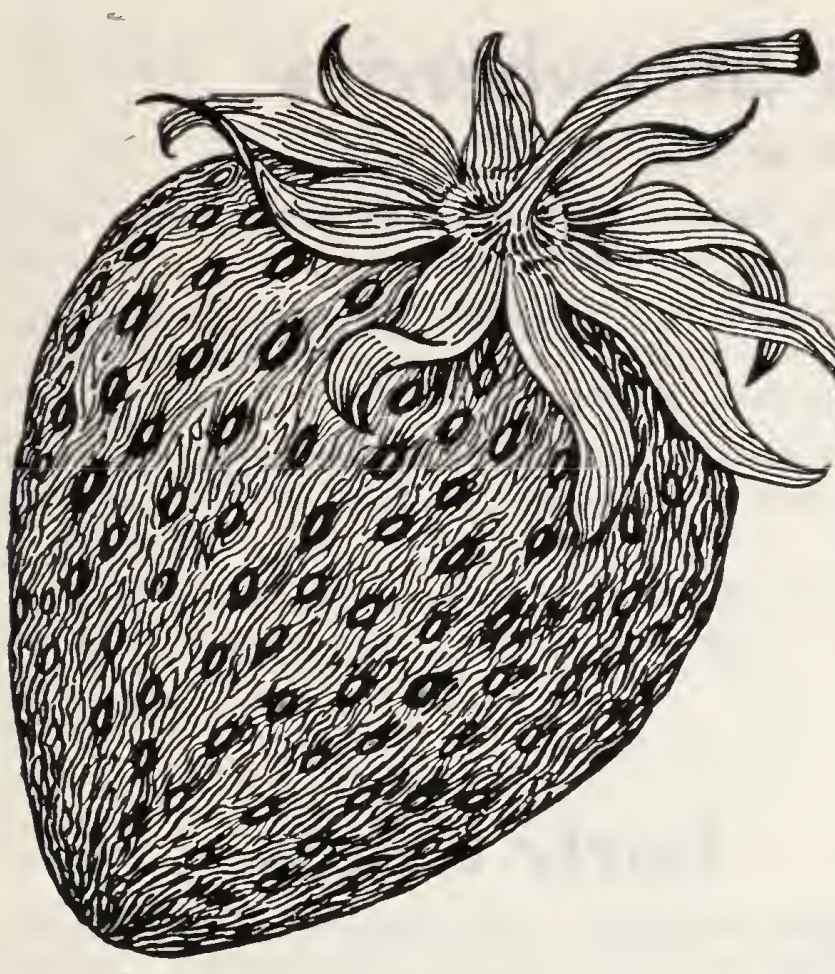

\section{Strawberry Plants}

\section{Grown by Modern Methods}

That is, from parent plants not allowed to weaken themselves by bearing, and which are treated by fungiide, insuring perfect health. It inreases the crop 10 to 50 per cent according to season.

What do we mean by plants grown by Modern Methods? See page 8 for full description. To prove that we are right or wrong write to your State agricultural department and ask them what effect that method of growing will have on the health of the Sitrawberry plant.

\section{Too Many Varieties}

There is only confusion in the endless number of kinds of Strawberry plants now offered for sale. We have tested nearly every variety that has come out in the last forty years. Varieties that twenty years ago we found worthless, or at least inferior to others of the same class, are still being pushed and sold. We believe that we hare done a real service to the public in sifting out the kind most generally successful over the whole country and dropping the undesirable or unnecessary varieties.

\section{We Grow Our Own Plants-No Second-Hand Plants Sold}

We are one of the few large Strawberry plant shippers that grow all of their own plants. Nearly all of the others are situated in the midst of thousands of small growers, who grow berries for market, and from whom their plants come at second hand. Of course, there is great risk in setting plants grown in this off-hand way. You run great risk, not only of buying mixed plants, but of getting absolutely the wrong kind. Then there is the very serious danger of disease-the deadly black root, weevil, etc.- which once brought on your land would quickly drive you out of business. Among so many growers, constantly bringing in new varieties from every quarter, more or less disease is unavoidable. That we make enemies by this statement and draw attacks upon us, we well know. But we are stating facts-the plain, unvarnished truth.

We are in a natural Strawberry region separated by a hundred miles or more from all other growers. Our plants are grown on our own farms, and on rigid scientific principles.

\section{How to Grow Big Crops of Strawberries}

A large part of our 100-page book, "Modern Methods in Fruit-Growing," is devoted to the Strawberry. It shows by plain cuts the best and most economical implements to use, and exactl. how to set the plants for quick growth. It tells how to select the best land; how to grow for home use or market; how to plant. manure, cultivate, gather, and pack. It gives a simple, effective mode of protecting blooms from frost.

In short, it follows the Strawberry from the time the plants arrive at vour place till you sell the fruit and pocket the money. Nor does it stop there. It follows the fruit $y o u$ raise into your home and tells the housewife the numbelless ways it can be used as dessert. How to make delicious Strawberry shortcake; Strawberry ice cream; how to preserve, can, make jelly, Jams, etc.

THIS BOOK IS FREE WITH EVERY ORDER OF \$5 OR OVER, AND WITH THE COLLECTIONS ON PAGES $3,4,5,13,14,15,20,35$, and 45

\section{OUR MODERN METHOD PLANTS FRUIT BETTER THAN GREAT PEDIGREED PLANTS FROM OTHER NURSERIES}

I have for years given your name and address to customers wanting nursery stock and advised them they could not get betten any where else. I wish to assure you that I know what I am talking about when I say you have the best plants I have seen in my many years of canvassing. I sold your stock 27 to 32 years ago for a nursery that bought plants frcm your nursery. I sold your berries and saw them fruiting by the side of other great pedigreed strawberry plants from other nurseries. Your plants fruited better and made larger berries. A. G. Williams, Charlotte, N. C. Jan. 20, 1931. 


\title{
Extra-Early Strawberries
}

\author{
Price List on Page 43
}

Excelsior. A standard extra early variety that succeeds everywhere; firm, brilliantly colored. Fine table berry when perfectly ripe.

Blakemore. (New variety just introduced). Vigorous, very resistant to dis. eases. Has a brilliant color which it holds well after picking. In Eastern North Carolina it is from 2 to 4 days earlier than Missionary.

Missionary. Ranks fully up with Excelsior as a standard extra-early shipper and table berry generally. In most places it is taking the place of Excelsior. A heavy bearer of fine fruit.

Heflin's Early. In large regions of the South and central parts of the country, Heflin surpasses all other varieties in large size, brilliant coloring, and profitableness.

Premier. A popular early variety in some sections.

\section{Early Kinds}

Genuine Klondike. This is the standard early shipping berry. It succeeds everywhere. Ripens close on the heels of Excelsior and Missionary. Productive, brilliantly colored and so firm that on the great northern market it classes as a reshipper, that is, a berry firm enough to reship to the smaller tributary markets, and therefore commands topnotch prices. There is another entirely different and far inferior variety masquerading under the same name. We have the genuine Simon-pure Klondike. Fine table berry when perfectly ripe.

Lady Corneille. Similar to Klondike and, like it, a great drought-resister. Regarded by many as a distinct improvement, even on that magnificent variety, and as the coming market berry.

Lady Thompson. Ranks with Klondike as a standard market berry.

Senator Dunlop. The standard all-purpose berry through an immense region $\$$ of the West and Northwest. Specially valuable in regions subject to drought, being equal to Klondike as drought resister.

Brandywine. A large, highly productive variety that fruits continuously for $0^{\circ}$ a long time. Succeds everywhere.

\section{Midseason Kinds}

Haverland. A sure and enormous bearer, but berries are too soft for anything but home use or nearby market. It has also the habit of fruiting close to $\mathscr{\complement}_{2}$ the ground and needs careful mulching. Pistillate, pollenize with any good staminate like Brandywine, Klondike, or Dunlop.

\section{Largest and Handsomest Berries that Grow}

Giant. Under this head we class several varieties that combine huge size, brilliant color, and the finest flavor. Will send the kind best suited to your locality. These plants are grown specially for gardens and home market growers.

The strawberry plants I received the first part of January are doing fine. Did not lose a single one and some of them are as large as the crown of your hat and keep me busy picking off blossoms.

J. T. Magruder, Los Angeles, Calif. March 25, 1931. 


\section{Late Strawberries}

Aroma. Like Gandy, everywhere a standard late berry. Some pronsunce it even ahead of Gandy and a heavier bearer and thriving in all kinds of soil and climates from Maine to Florida.

Gandy. Shares with Aroma the kingship of all the late kinds. A magniticent berry in all respects. Very large, of perfect shape, glorious color excellent flavor; a standard large berry. Its firmness and meaty quality makes it not only a fine shipper but also fine to can and to preserve. Gandy thrives everywhere.

Chesapeake. Good late variety. Perfect flowering, with uniformly good-sized fruits. Because of the stout stems, the berries are very easily picked.

Next to the great standard varieties like Klondike, more money has been made on the very late kinds than on any others. 'I'hey not only ripen after most kinds are gone and the market bare, but their large size, brilliant coloring and their first-rate Havor give them the command of the market.

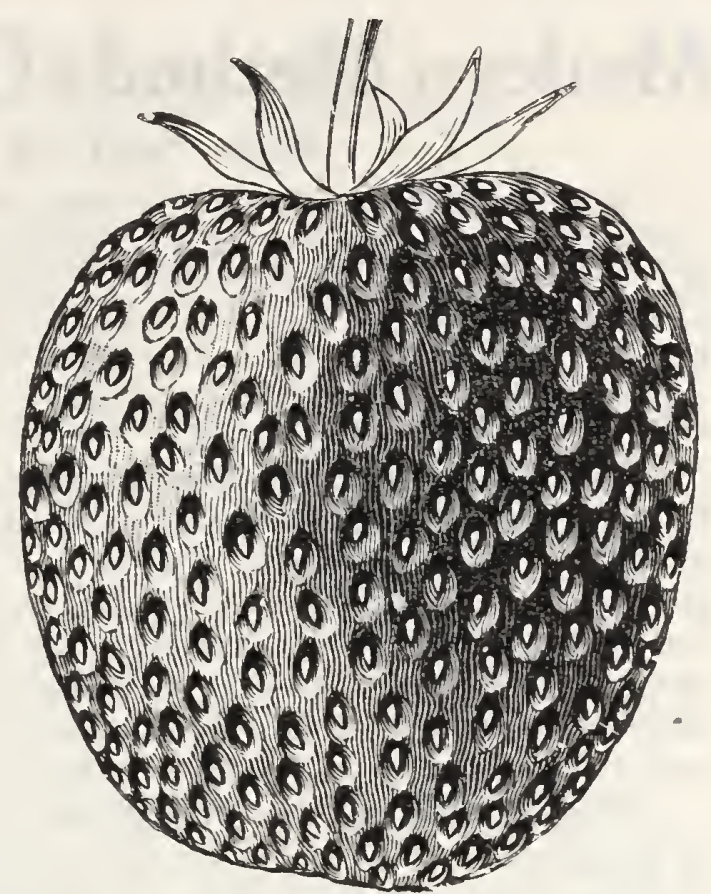

\section{STRAWBERRY PLANTS BY MAIL}

Strawberry plants will be delivered by parcel post at the following rates. You can easily find out from your postmaster what zone you are in with reference to Kittrell, N. U. and then you can send postage according to the table below, unless you are ordering a collection of plants or trees which is delivered free.

\begin{tabular}{|c|c|c|c|c|c|c|c|c|c|c|}
\hline \multicolumn{3}{|c|}{ Zone } & 1 & 2 & 3 & 4 & 5 & 6 & 7 & 8 \\
\hline 100 & Plants & $\ldots \ldots \ldots \ldots$ & $\$ 0.08$ & $\$ 0.08$ & $\$ 0.10$ & $\$ 0.12$ & $\$ 0.15$ & $\$ 0.18$ & $\$ 0.22$ & $\$ 0.25$ \\
\hline 200 & Plants & $\ldots \ldots \ldots \ldots$ & .10 & .10 & .14 & .20 & .27 & .34 & .42 & .49 \\
\hline 300 & Plants & $\ldots \ldots \ldots \ldots$ & .12 & .12 & .18 & .28 & .39 & .50 & .62 & .73 \\
\hline 500 & Plants & $\ldots \ldots \ldots \ldots$ & .16 & .16 & .26 & .44 & .63 & .82 & 1.02 & 1.21 \\
\hline 1000 & Plants & $\ldots \ldots \ldots \ldots$ & .26 & .26 & .46 & .84 & 1.23 & 1.62 & 2.02 & 2.41 \\
\hline
\end{tabular}

\section{A STATEMENT AS TO NEW VARIETIES}

Our method of doing business, of cutting out and denouncing the tree agent, who as a rule, not only gets 50 to 75 per cent commission, but whose slick tongue often foists upon the public all sorts of worthless varieties of trees and plants, has made us many enemies. For, strange to say, most of the nursery strick of the country is still sold in that oln before. the-fiood way. The result of our attitude in this respect is that many of those old-method nurserymen, their agents and henchmen, attack us in all sorts of ways-openly, secretiy, in the papers and out of them. They have been at it for forty vears, but we have thriven by it, for the perple to whom our method of selling direct has saved hundreds and thousands of dollars see through these attacks and stand by us.

This time we are being attacked because when we tind a new or apparently new variety of fruit we par more attention to its merits than to its antecedents. If we had given all the attention to the history and origin of the fruit and none to its quality it would have been all right, no matter how worthless it was or how much fraud and deception was practiced to sell it.

For forty years and more we have kept keenly on the lookout for varieties of fruit that were better than those in common use. If on full trial one that we found or had sent to us proved good, we propagated and sold the plants or trees, paying little attention to their antecedents. In fact, that seemed to us a matter of little imprirtance provided the fruit was good. If the fruit had a local name we adopted it; if none, we gave it one.

Among the rarieties thus propagated are the Ellis Hunt Everbearing Apples (Varie. ties that ripen continuously from June to August): the Summer and Fall Ambrosia Apple; the Wine, Ambrosia, Four-in-One and Neva-Myss Peach; the Giant and Never-Stop Strawberry, etc.

We are not absolutely sure that all of them are new varieties. We are dead sure that they are good varieties. That is the main point, compared with which others are tritles. 'The Strawberries were propagated from single plants found in a neglected spot in an old orchard, where for vears countless varieties have been tested: as none of inem proved of unusual merit we had reason to believe that a plant of great value found among these orchard plants was a seedling and a new variety

CONDITIONS OF SALE-Under our rigid system of marking trees, plants, etc., it is almost impossible for an error to occur. But, if it should, and the wrong variety of any fruit be sent, we will replace it free or refund the money on satisfactory proof of the error. But further than this we will not be responsible in any respect, and all stock is sold under that understanding and no other. Never-Stop Strawberiy and Neva-llyss Peach are sold on the condition that the buyer will not sell or give away any trees, plants, or buds of either. 


\section{Modern Methods Quick Fruit Plant-Food}

\section{Gives You Fruit Quicker and More of It}

Usually, though not always, large fruit-growers are able to get suitable manure or fertilizers, or at least something similar to it. Small growers, people who grow fruit to lessen the cost of living, to eke out a slender income, those who can least afford to blunder, have to put up with anything they can get, which is nearly always the wrung thing. Millions of dollars are wasted that way every year, and tens of thousands of people deprived of, or scantily supplied with, fruit who might have it in abundance.

After years of practical test we have compounded odorless, inoffensive plant-food, which any lady can handle as she would meal or flour, and which will greatly increase results.

The Plant-Food for Everbearing Strawberries and Raspberries is compounded to greatly increase the quantity and size of the fruit rather than to promote plantgrowth. Plow or hoe in deeply half the plant-food before planting; hoe the remainder in lightly around plants the following spring. The Everbearing Strawberry, fruiting heavily through the heat and occasional drought of summer and fall, must not be so heavily manured as to cause "firing" of the foliage. If stable manure is used to enrich the soil before planting, it must be well rotted and deeply and thoroughly mixed with the soil. Best to use only the plant-food.

The Plant-Food for Fruit-Trees and Rose Bushes is highly concentrated (highly ammoniated) so as to promote rapid growth and bring the roses into full bloom the first year and the fruit trees into fruiting younger than ordinary fertilizing.

By using this food and planting, pruning, manuring, and cultivating as we direct, you get fruit about one year sooner than in the ordinary way.

You can easily prove this by comparing a young tree fertilized with our treefood and one on which the same quantity of ordinary fertilizer is used. With fruit trees and rose bushes this plant-food puts in its work in rapid growth the first year and afterward must be supplemented with other manure as directed in book. (See label on plant-food and our book for full directions.) Do not understand by this clause that this tree-food increases all the fruit crops to come; that depends on future manuring and treatment of the tree.

\section{Modern Methods Fruit Book}

A book that no one who sets a fruit tree or plant can afford to be without. Embraces and puts in helpful form the practical fruit-growing experience of forty years.

Realizing the urgent need for quick results in this driving age, this book shows how to get these quick results. Other books tell; this book tells and shows. Pictures tell plainer than any words the whole interesting story of fruit-growing from the moment that the plant or tree arrives at your place till the ripe product is eaten or sold. It shows how to dig the hole for plant or tree, how to fill with soil, manure, and fertilize, how to prune the roots, how to prune the tops the first, second and third year, and how to give the final shape so that the sun can get in and give color and flavor to the fruit. It shows how to plant, manure, and prune a hedge to get perfect results before the first summer is half past. How to get perfect roses the first year and a fine shade tree in three to four years. It shows how to grow strawberries; how to plant, manure, cultivate and handle them, and all other kinds of small fruit. How to make an asparagus bed that will last a century and give a large supply of this delicious vegetable every year from April to August. Not only does it tell the big points but it tells and shows the countless little ones that other books do not, but on which success depends. No other book on growing fruits, ornamentals, etc., covering anything like the ground that this does, or covers it so thoroughly and plainly.

And not only does it give outdoor instructions, but it follows the fruit indoors and tells the lady of the house exactly what to do with it. A whole department is devoted to this subject. It tells how to serve all kinds of fruit. How to make all kinds of fruit ices and desserts. How to can, preserve, make jellies, jams, wines, cordials, and everything connected with the serving or preserving of fruit. Last, not least, it is all compressed into a compact 100-page book that can be carried in your pocket.

It Is Free With Every Order of $\$ 5$ or Over and With Collections on Pages $3,1,5,13,14,15,20,35$, and 45, If Asked For. 


\section{Neva-Myss The Earliest of All Peaches}

\section{THE ONLY ONE THAT HAS NEVER MISSED A CROP, FRUITED 27 YEARS. HAS PAID $\$ 1,400$ A SOLID ACRE}

\section{(Price List on Pages 43-44)}

Of course, these are exceptional profits, but an average net profit of $\$ 250$ to $\$ 400$ an acre is within the reach of any live man living near a town or with fair shipping facilities.

There is large profit in the Neva-Myss because it ripens in May long before any other kind begins to turn, and creates a sensation in any market, big or little, or in any neighborlood it takes them by surprise by its earliness.

This effect is immensely increased by the fact that Neva-Myss stands clear outside the common run of early Peaches. They are small, pale and tasteless; Nera-Myss is a large, brilliant, red Peach of good quality.

Has paid $\$ 1,400$ a solid acre, and also lias paid $\$ 5.75$ a tree at two years old, $\$ 30$ at four years.

There is sure profit in it because it never misses a crop. Fruited twenty-seven years, witl only one light crop-1918 - all others heary-no dark mystery about this-simply plain everyday cause and effect. It is well known that most early Peaches have the liabit of blooming late. They bloom much in a bunch-quick to come and quick to go. If frost hits them, no Peaches hit that year. Nera-Myss is the latest of all to begin blooming, but it has another safeguard that most of them are lacking in. Neva-Myss keeps at it gradually for weeks. Frost may come again and again, still there are enough blooms left to make a ful crop. Indeed, occasionally, when no' frost at all comes to thin them, it must be done by hand, if large Peaches are desired.

Neva-Myss, too, has in greater degree than most Peaches the habit of retaining for long while the "shuck" or butt of the bloom. This dies, dries up and forms an effective overcoat, as it were, for the young Peaches.

There is quick profit in it because the trees usually begin to bear a year younger than most other kinds. Now there is no dark mystery here. A Neva-Myss at three years old usually fruits like a four-year-old-tree, simply because at three years old it is apt to be as large as most kinds at four years old.

\section{Six Select Trees $\begin{aligned} & \text { With Modern Methods Plant-Food and Modern } \\ & \text { Methods Fruit Book, all delivered free for ........ } \$ 4.50\end{aligned}$}

Trees in all collections are the very pick of our immense stock, so perfectly balanced in root and branch growth that they will grow fast and come quickly into bearing. 'They are put into perfect shape before leaving us by being pruned root and branch precisely right, saving you all doubt and trouble in that respect. 'lley are packed with extra care so as to arrive as fresh as when dug. With each collection is sent enough strongly concentrated (highly ammoniated) Mcdern Method Fruit 'Tree Food to push the trees into quick growth and fruiting. This food, combined with their superior vigor, brings them into bearing at two years old, a year younger than ordinary trees.

We also send our 100-page book, worth $\$ 25$ to any fruit-grower because it not only tells, but shows, by clear practical cuts, how to plant, prune, manure, and cultivate all kinds of fruit. Page 12 tells also about the book and fruit tree food. See pages 3 and 4 for collection of Peaches selected for their delicious flavor, ripening without a break from May to November.

AS TO BEING FROSTPROOF. Again some of our competitors attack us on this point claiming that there is no such thing as a frostproof Peach. ITe do not claim there is. We simply state that Neva-Myss has been fruited twenty-seven years and has never missed a crop, and we give the reason why. 'That it is a late and gradual blocmer, and that enough blooms always escape frost to make a fine crop.

\section{WHAT VICE-PRESIDENT OF BANK HAS TO SAY ABOUT OUR NEVA-MYSS}

This was our first year shipping car lots-the first car of Neva-Myss to Cincinnati of around 500 crates of three-quarter busliel each sold gross over \$1,500.00, and the House wrote us this sale broke a 15 -year record for early peach sale, also wrote us the Neva-Myss stood up beside Georgia goods and outsold them $\$ 1.00$ per package. So that's our experience with Neva-Myss.

C. P. Perkins, Vice-Pres., Batesville, Miss. Aug. 14, 1931.

Twenty-three years ago I hought from the Continental Plant Company some Neva-Myss peach trees. They were a joy and were named right for they never miss bearing.

Mrs. Nathan O'Berry, Goldsboro, N. C. Feb. 11, 1931.

I have two of your Neva-Myss peach trees (on a small city lot). They are six years old. When should I plant others between so they will come in by the time the old trees begin to fail? I don't ever want to be without a Neva-Myss in my back yard. 


\section{Specialty Peach Trees}

(Price List on Pages 43 and 44)

Peaches not only make the daintiest of desserts, Peaches and cream, ice cream, preserves, jellies, etc., but they are the leading canning fruit. Peaches that are not sold or consumed fresh can be turmed into money by canning.

It is generally conceded that the Peach is not only the most beautiful, the most delicious but also the most wholesume of all tree fruits. Why not enjoy it from May to November, including both months. It is perfectly practical to do so. See page 3 for trees delivered free with book and tree food.

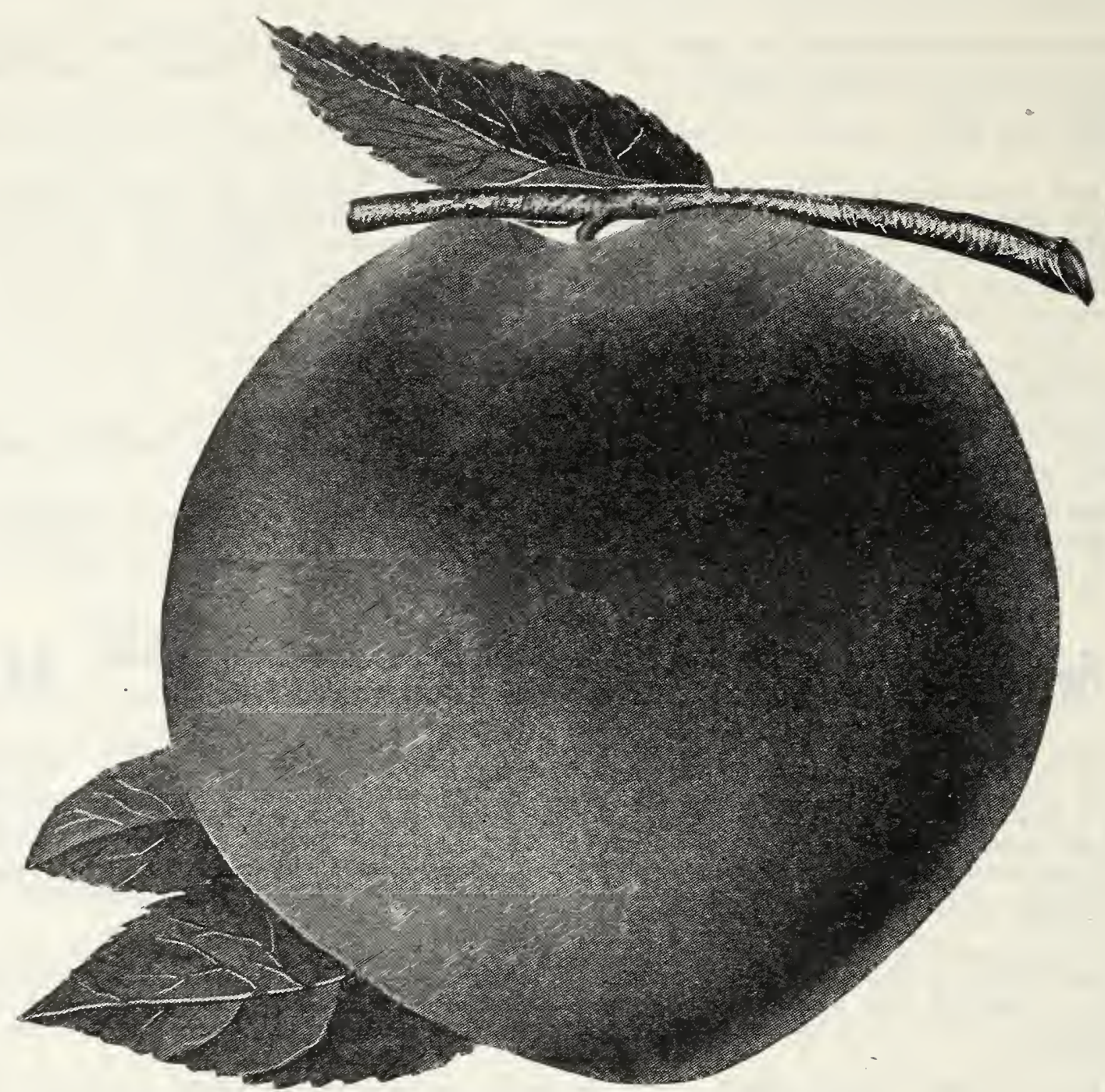

\section{The Giant Four-in-One Peach}

This is far and away the largest Peach that grows. It is the firmest of all mid-summer Peaches. Its grand size and glorious colcring makes it certainly one of the very handsomest. while when fully ripe and soft it has no superior and few equals in delicious tlavor. It colors up deep cream and crimson long before it softens. 'This adds immensely to its value as a shipping and market Peach, for it can be gathered when well nigh firm as a cannon ball, shipped 2,000 miles to market, and softens at leisure. 'l'hen its veritable nectar, clear seed, suft. juicy, melting-all that a perfect Peach can be, and is fully entitled to the name it bears, as it would be from ancther point of view, to wit: the best seller, the best eater, the best canner, the best preserver. In fact, it is king of all mid-season varieties, just as Nera-llyss is of all the extra early sorts, and like it, it is a quick grower and enormous bearer. 


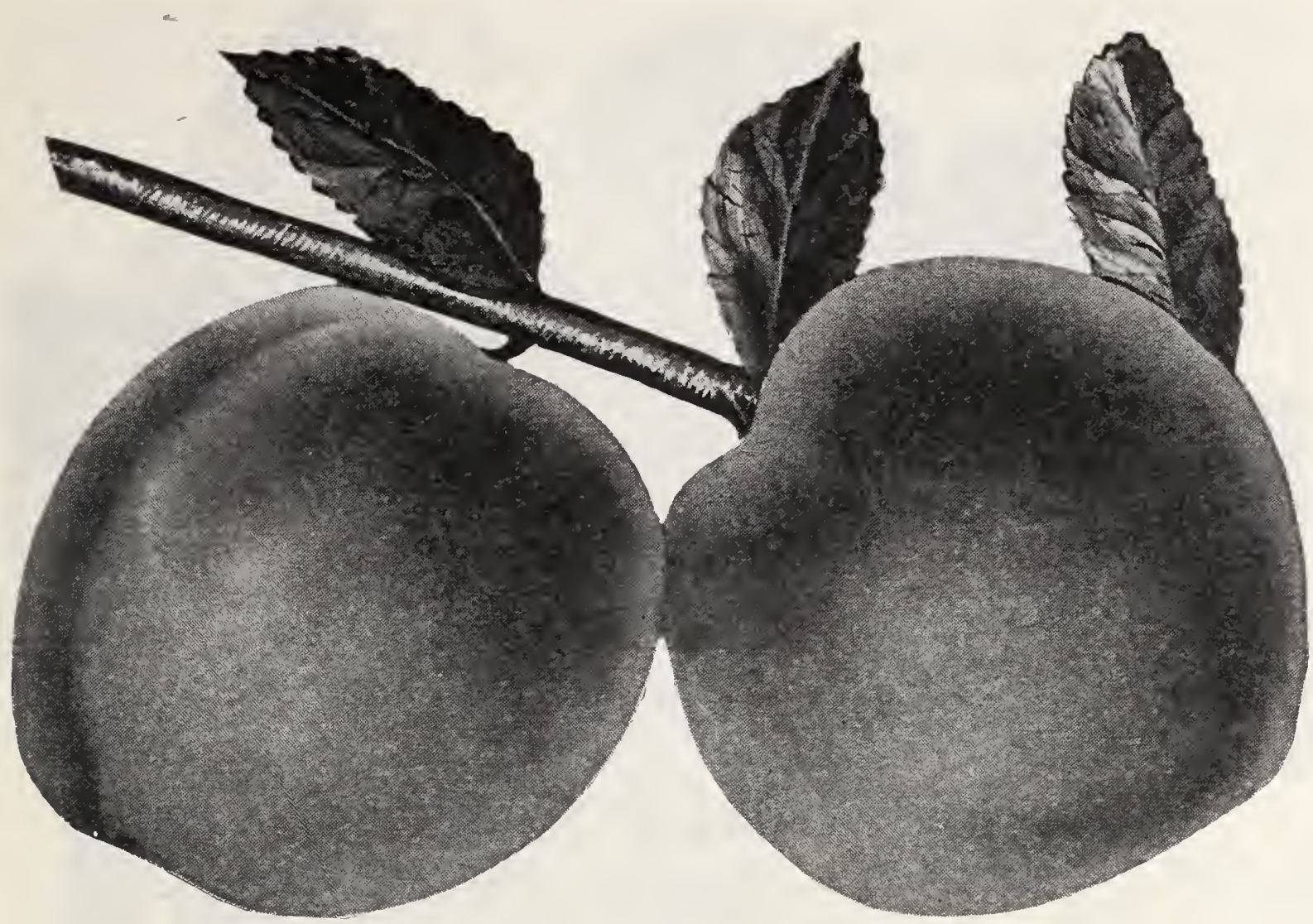

\section{Exquisitely Flavored Table Peaches}

The following superb varieties of soft, clear seed Peaches are for home use ur strictly fancy market. Their exquisite Havor fits them for Peaches and cream. ice creain, or they are delicious eaten right from the tree.

Ambrosia (Food of the Gods) ripens in early July. Niagara in late July. and Wule Peach in August, while Neva-Myss and Four-in-One color up long before ripe and are usually picked and shipped to market in this stage of ripeness. If allowed to ripen thurminly on the tree, they rank well up with the fine table Peaches.

\section{$\forall$ Ellis November}

This is the only Peach we have ever seen that really ripens in November $\| 1$ a free. stone and a Peach of medium size and of splendid fiavor. It is a seedling found in this neighborhood and we have been watching it fur years. it is frepr from dinease than any variety we have seen and the beauty of it that it matures fruit and it ha. nol minsed a crop for four years we know. We highly recommend this rariets for h.me tlse or for home market. (See cover page for a picture of this splendid varlety.)

\section{Ambrosia (Food of the Gods)}

The most exquisitely delicious Peach yet produced (tear seed. suft and meltug. A revelation in Peach tlavor. A heary and sure beilrer. ripening in July. Colur beantiful cream and crimson. So delicious that it can be eaten with rream withou sisgar. makıng it wholesome for even the weakest stomach.

\section{Niagara}

An immensely large, brilliantly colored. expuisitely Hatored Peach of thr theria lype, but much earlier and far superior to it in quality. It seems certain that Niagara will take the lead of the class of the strictly fancy Pearhes. for it is in size, colnr. and pruductiveness not surpassed by any of them and not approached in flavor by the hest of the giant Pearhes. Ripens in early August.

\section{Wine Peach}

A beautiful red-cheeked, medium-sized Peach of the most dehcums Havor claar seed. soft. so luscious that it can be drunk like a glass of wine. which it resembles in thivir. It has the almost unique habit of propagating true from the seed. lou call grow all the trees you want by simply plantiag the seed. Has been gr $\rightarrow$ wn here from seed for tifty years and has never missed a crop. This gives a rare and distinct value to the lline Peach 


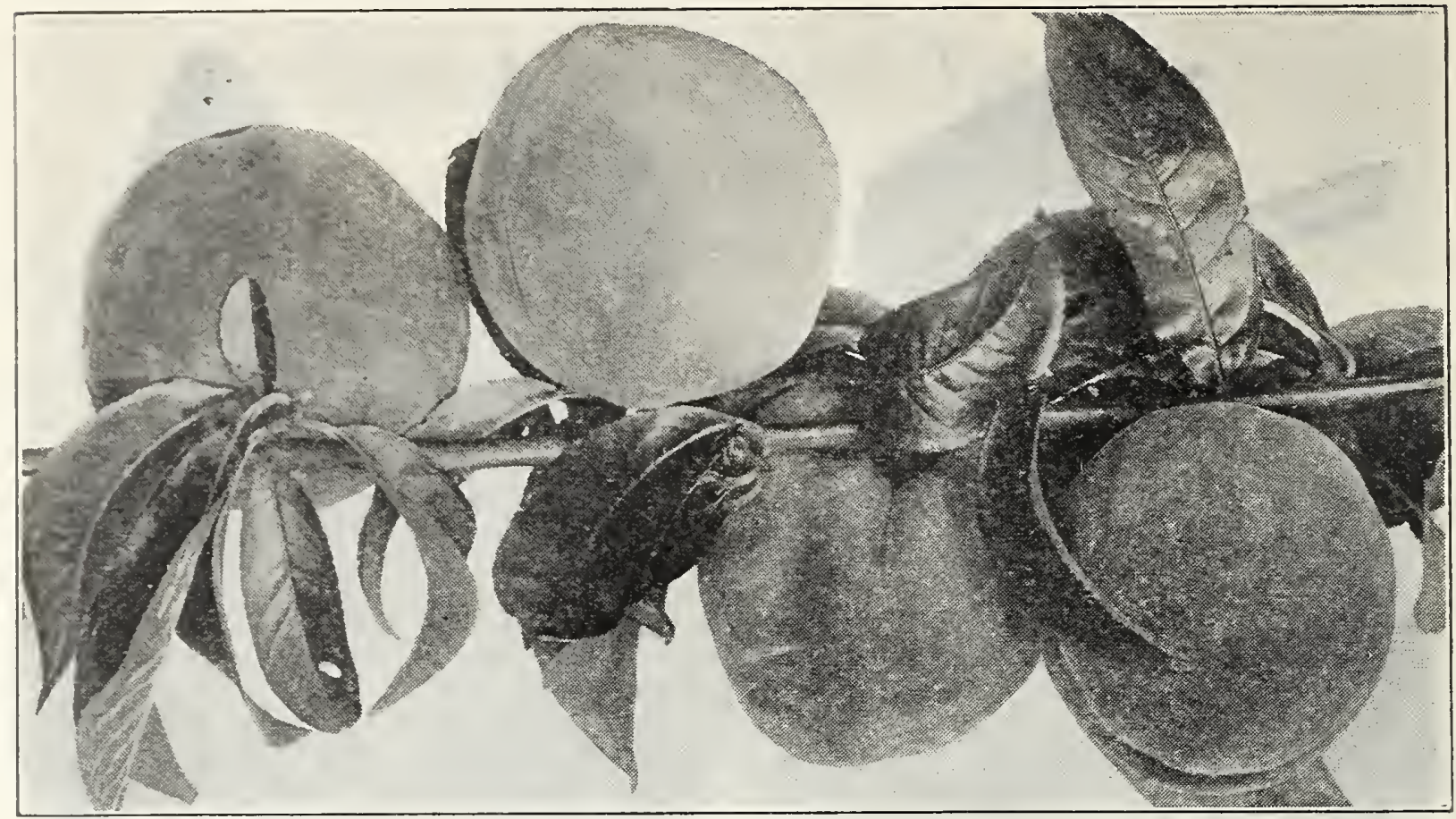

\section{Extra-Early Peaches}

(Following the Neva-Myss)

(For Price of Following Trees See Page 44)

Mayflower. An early peach-ripening before Sneed.

Sneed. This is recognized as one of the standard early Peaches over the whole country. It follows Neva-Myss closely, ripening early in June. It is of good size and is unusually productive; a fairly well-colored Peach, which is so luscious that when ripe it can be drunk like an orange.

Arp Beauty. An early Peach of good quality.

Alexander. An early Peach. Popular in some sections.

Greensboro. This is a glorious mid-June Peach. In size it ranks among the very largest. Its color is an exquisite cream and crimson and in quality is luscious and melting. Succeeds generally throughout the country and as far south as the Gulf of Mexico.

Dewey. This is a large, exceedingly handsome, red and yellow soft Peach. The trees are fine growers and heavy bearers. It is one of the few really fine varieties that succeeds generally throughout the country and in Florida, where it thrives well, except in the extreme southern part. Follows sneed closely in time of ripening.

\section{Early Peaches}

Carman. A very large, brilliant red Peach of excellent quality and immense productiveness. Soft and nearly freestone when ripe. Equally good for home and market, being firm and a fine shipper. Does splendidly throughout the country clear down to the Gulf of Mexico. Ripens in June.

Belle of Georgia. Another of the great cream and crimson Peaches. An exceedingly showy Peach and a good one, too. An excellent shipper, firm and a good carrier, though a freestone, and soft and luscious when thoroughly ripe. Succeeds generally throughout the country down to the Gulf. Early in July.

Burke. A mammoth, superb, white and red Peach of showy appearance and good quality. Late July and early August. Clingstone.

Chinese Cling. A large white Peach shaded with red; fine quality. Late July.

Stonewall Jackson Cling. Similar to Chinese Cling, of which it is a seedling, but a decided improvement on it. A really magnificent Peach. Last of July.

Early Elberta. Type of this grand variety ripening in early July. 


\section{Midsummer Peaches}

Elberta. Easily king of its ripening season. A mammoth gold and crimson reach of excellent flavor. Famous for its vigorous growth, immense productiveness, and adaptability to all soils and climates. Great for home use, for market, and for all purposes. 'Ihrives generally, and even as far south as Florida. Freestone. August 1.

CAUTION.- There are two, if not three or four varieties, differing greatly in merit, called Elberta. We have the genuine Elberta, on which so many millions have been made by the Georgia growers.

J. H. Hale. A fine peach of good shipping qualities.

New Prolific. Similar to Elberta, and one week later. Valuable to keep up the succession of Peaches. Freestone.

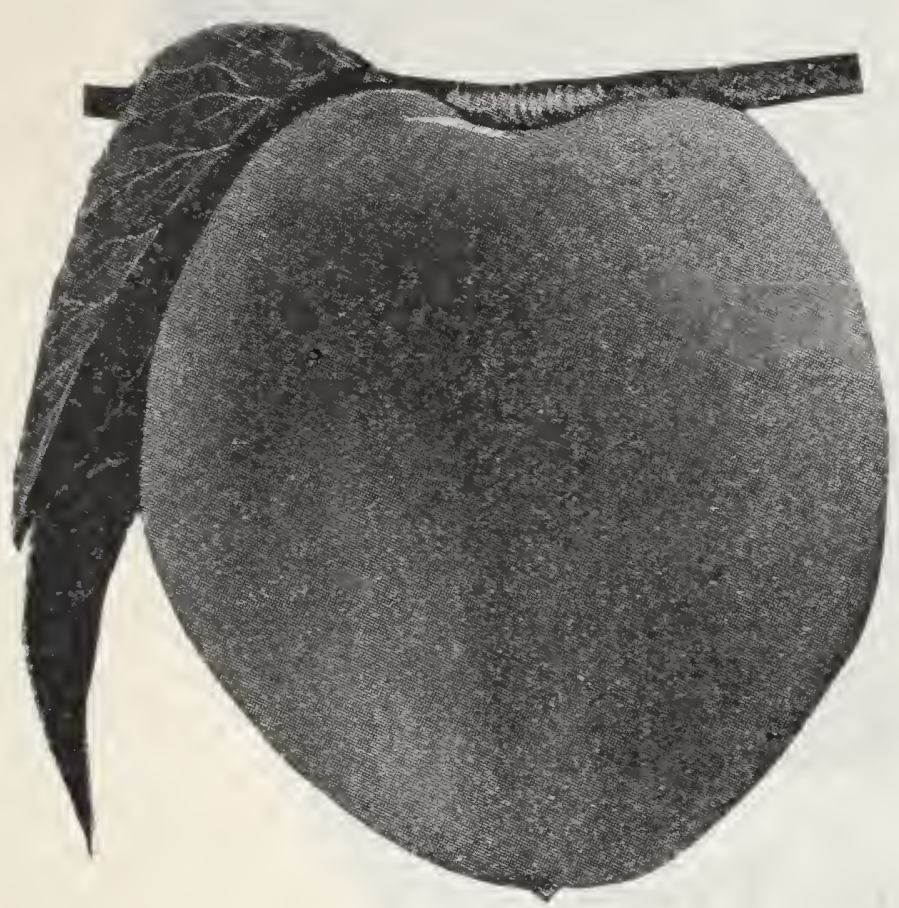

Crawford's Late. Another splendid red and yellow Peach. A trifle later in ripening than Globe. Freestone. Does well even as far south as k'lorida.

Stonewall Jackson's Free. Said to have originated from a seed brought by a Confederate soldier from the Gettysburg campaign in 1863. A giant gold and crimson Peach of excellent quality. Noted as being a sure bearer. Valuable. Late August.

old Mixon Free. A large, white and red, soft Peach of tine quality. Late August.

Matthew's Beauty. Another excellent red and yellow Peach. Free. stone. Last of August.

Honey. So many of our customers ask for the old-fashioned Honey Heach we decided to put it in stock. It is a freestone, medium sized peach. We have the genuine old-fashioned Honey.

Indian Freestone. An old-time favorite wherever planted and grows to a large size; dark red flesh; a deep red; highly tlavored.

\section{Fall Peaches}

White Heath. A large, white, clingstone Peach of excellent eating, canning, preserving, and selling qualities. First half of September.

Eaton's Gold. A very large, tinely tlavored, gold and crimson Peach. Valuable for all purposes. Said to have originated here from seed sent from Japan before the war, about 1855. Clingstone. Last half of September.

Durham or Flinton's October. A magnificent, late, white Peach. Considered far superior to even the Standard White Heath.

Albright's October. A large, white, well-flavored Peach for any season, doubly valuable because it ripens so late. Clingstone. Hirst half of Uctober.

Stinson's October. A standard very late Peach.

\section{Peaches All Year}

Before you decide which of these varieties you wish to grow, turn to pages 3 and 4 and see if our great Peach collection would not be the best thing for your home garden. Look also at the pictures of Peaches on the cover. The twelve kinds we offer will furnish the table with fruit all season long; you'll have plenty left to can and preserve, or to sell.

The professional fruit.grower prefers to grow only four or tive varieties, as they will furnish a complete picking season and keep a band of men busy from the beginning until the end of the season. The home grower, however, wants trees which are always ripening throughout the season. We think our Peach collection on pages 3 and 4 suits the homogarden better than anything else you might select. 


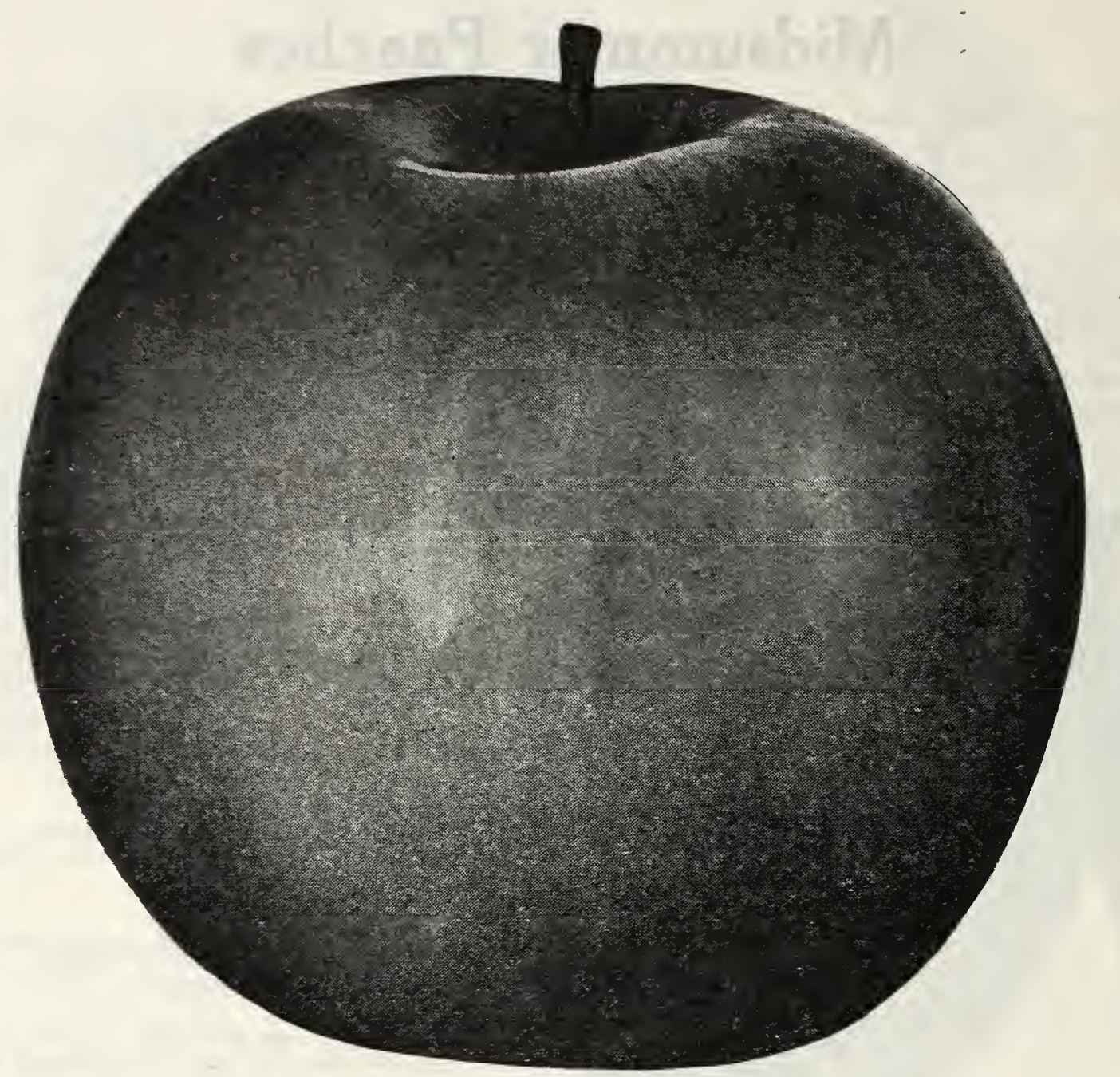

\section{Apple Trees}

\section{HAVE APPLES THE YEAR ROUND FROM YOUR OWN TREES, ALL-THE- YEAR-ROUND COLLECTION OF TREES DELIVERED FREE WITH TREE FOOD AND BOOK. SEE PAGE 5}

By intelligent people the Apple is now deemed almost as indispensable an article of foor as bread itself. It is food, medicine, and no mean moral agent all in one. Indigestion, bladder and kidney trouble, and rheumatism, which has its chief seat in such troubles, are benefited and often cured by the liberal eating of Apples. People, especially boys, who eat Apples freely do not have the same hankering for dope, drink, and tobacco as the non-fruit eaters.

The only way for the average family to have Apples is to grow them themselves. One good tree of the right variety will yield more fruit than can be bought for $\$ 10$. We furnish trees of varieties that ripen in succession from May to November. With a little eare Apples can be kept through the winter till Apples come again. A cellar is best, but almost any dark, dry place will do, the cooler the better, so the Apples cannot freeze.

Any surplus of Apples can easily be sold if kept until winter. Still, it is often the case that summer and fall Apples sell well right from the tree if fine.

Thus, Summer Ambrosia would sell on sight, at any time, and if not then, surely by taste. Few people, if allowed to see its exquisite beauty and taste its delicious flavor, could resist it.

Then what a friend the Apple is to the housekeeper. The fresh Apple, of course, comes first, but then dried Apples, canned Apples, Apple marmalade and Apple butter stand her in good stead. Then there's Apple vinegar. One tree of Apples will yield many gallons, and there is really a crying demand for pure vinegar. For not even the shadow of an Apple ever fell in most of the vinegar we use, and we know it. 


\section{Apple Aristocracy}

(Price List on Pages 43 and 44)

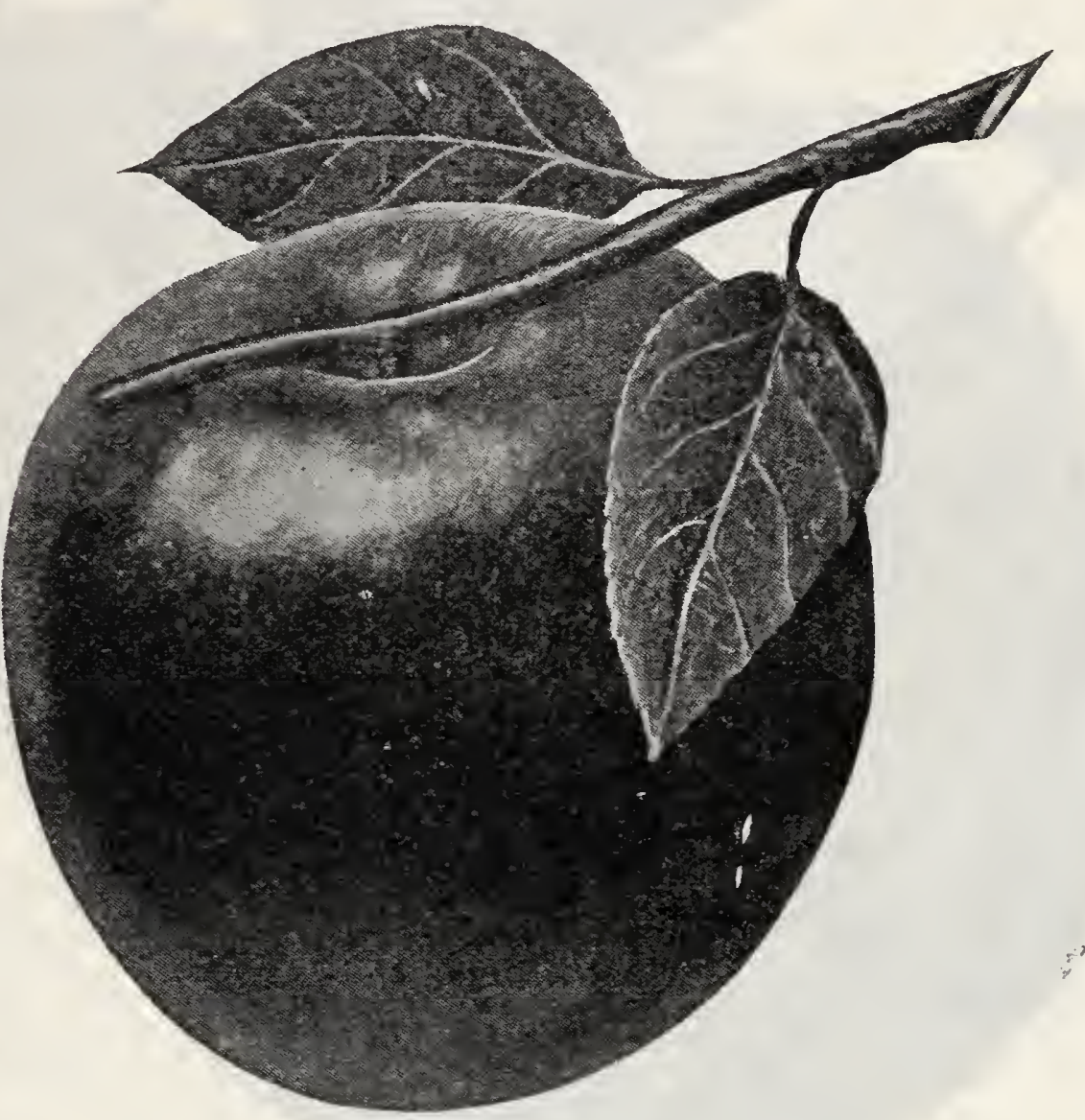

The following are the creme de la creme (cream of the cream) of Appledom, which thirty years' tests have enabled us to select as the very best, varieties of the Apple family.

Summer Ambrosia. A medium-sized, golden-flecked red Apple of the most excellent flavor. Till you have eaten one of these strains of Ambrosia you can have no idea of what a really tip-top Apple can be. Ripens in August when apples are scarce.

Fall Ambrosia. Superior in flavor even to the Early Ambrosia-that is, if sach a thing were possible. Very large, brilliant red. Ripens in the fall and keeps all winter.

Dixie. A superb fall and winter Apple for the South. Originated there, and will there. fore succeed much farther south than any other Apple.

Ellis Everbearing. An excellent, large, yellow Apple that ripens from June to September.

Early Colton. Valuable because it ripens far ahead of all other Apples of any value. A large, handsome, well-flavored Apple, ripening in early June into a veritable ball of gold.

Hunt's Everbearing. A medium-sized Apple of most delicious flavor, ripening all through June, July and August.

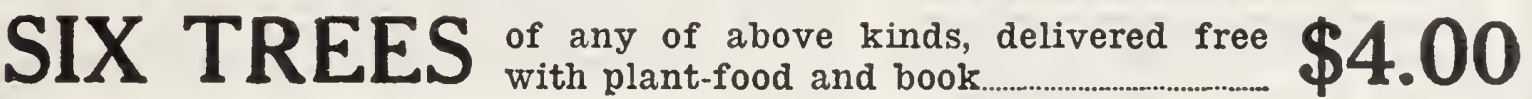

This Collection Carries Insurance Policy. (See Page 3) 


\section{General List of Apple Trees}

(See Pages 43 and 44 for Prices of Following Trees)

\section{SPRING AND SUMIMER APPLES}

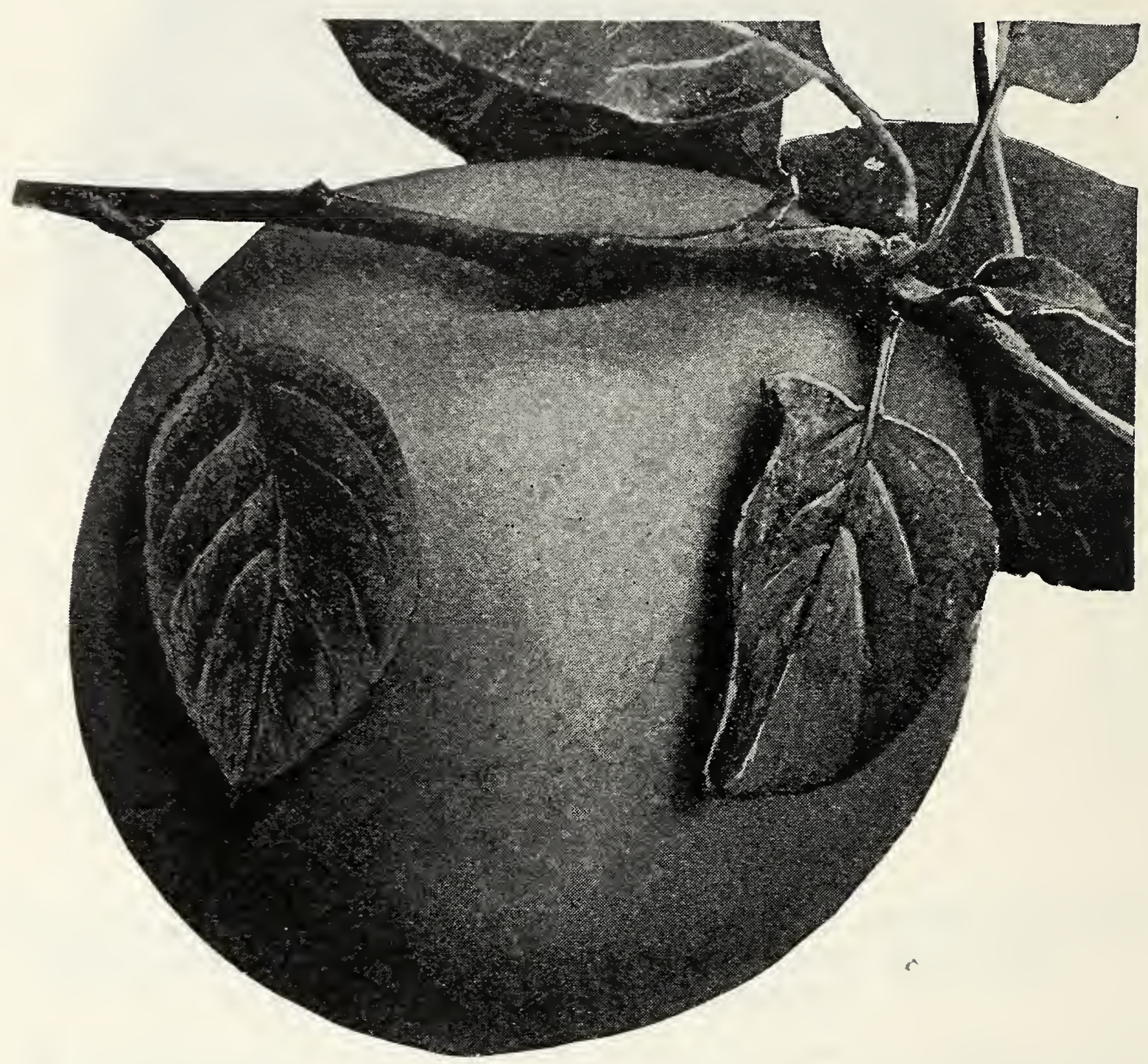

Yellow Transparent. This is a very fine Apple indeed; good quality, gocd size, beautiful, with a yellow tint; a sure and heavy bearer. A really delicious Apple. Ripens in June.

Red June. Hamous for its striking beauty and also for its sprightliness of Havor. With a coat of flaming red and meat of purest white it is one of the best known and the most popular of Apples. A good bearer, and though, only of medium size, a very valuable Apple for home use or to sell. Ripens in June.

Early Harvest. A widely known standard early Apple, valuable for its large size, excellent flavor, and is a sure and heavy bearer. F'ruit is pale yellow, streaked with dull red. Time of ripening, June. Early Harvest is universally popular.

Summer Pearmain. One of the most popular summer Apples. Ripens in July.

Horse. A large, old Apple, famous for its fitness for cider, pies, drying, and for all culinary purposes. When allowed to mellow to deepest gold, it is a delicious eating Apple. We have the genuine old-time Horse Apple of our daddies and granddaddies. Ripens in August.

OUR GUARANTEE broad guarantee given on page 35 by any nursery in the country.
Every tree, plant, shrub, bush, etc., etc., offered by us is strictly first class and is guaranteed to satisfy the purchaser. Note the It is, we believe, the broadest guarantee given 


\section{General List of Apple Trees-Continued}

May. Small round; pale yellow. One of the earliest apples and very popular on account of its earliness.

Early Joe. One of the best-summer apples ripening in. July. Medium size; streaked with red.

\section{Fall Apples}

Magnum Bonum (Great Good). The standard fall Apple. Famous everywhere for its immense productiveness and unequalled flavor. Really a most excellent and valuable Apple. In size it is medium, and in looks nothing extraordinary, but its quality leaves nothing to ask for. King of its season, which is late September.

Grimes Golden. A large, golden yellow Apple for exquisite tiavor, ripening in Uctober. A heavy bearer, and in all respects an Apple of genuine value, and of the very best of its season.

\section{Late Fall and Winter Apples}

Winesap. Named for its delicious, sprightly, winey flavor. A standard fall and winter Apple, universally popular, known to everybody and liked by everybody. In fact Winesap has everything in its favor-name, Havor, appearance, and productiveness. Winesap is an immense and never-failing bearer of large, Haming, red Apples, which color up months before they ripen, making the tree a most striking and ornamental sight through the whole summer and fall. No one can go amiss when he plants Winesap. It keeps all winter.

Stayman Winesap. A seedling of the famous old standard Winesap. Similar to it in many respects. A heavy and sure bearer, and a tine keeper. 'I'hrives in all soils and climate, like Winesap. Every orchard should contain some Stayman trees. 'I'he fine Havor and beautiful appearance of this Apple makes it a good seller, and no variety could surpass it for home use. Keeps till Apples come again.

York Imperial. Also called Johnson's Fine Winter. A very large, round Hattish, whitish Apple, speckled with red. Meat yellowish and of excellent Havor. Keeps till Apples come again.

Mammoth Black Twig. Also called Arkansas Black. Said to be a seedling of Winesap, which it resembles in appearance and Havor. A very large, blackish red Apple of tirst-rate tisvor. Ranks with those fall kings, Winesap, Stayman and York Imperial, as surpassing all others, as they do, in the few essentials of a first-class fall and winter Apple; productiveness, Havor, beauty and "keepingness," if we may be allowed to coin a much-needed word.

Red Limbertwig. A very large, pale-yellow Apple, sprinkled with red. Flavor, rich, juicy, and equal to the very best. A very tine Apple, keeping all winter.

Yates. A small, red, winter Apple, famous as a keeper and for its delicious tlavor.

Royal Limbertwig. Very large Apple; pale yellow, striped with red and a very. popular winter apple.

Russet. The old-fashioned Russet apple. We grow it as so many of our customers remember the old Russet and want a few of these.

Delicious. A variety too well known to need description. Extra tine.

\section{Crab Apples}

Siberian Crab. Fruit in clusters with long stems. Makes the best and most beautiful preserves.

Champagne Cider Crao. Makes delicious cider as well as preserves. We consider it one of the best crabs on the market, and it is a variety we introduced.

Hyslop. Hruit large for its class. Grows in clusters. Color dark rich red. Good for preserving and for cider.

Transcendent. A splendid and popular crab. Red striped.

\section{SURPRISED APPLES AND PEACHES BEARING TWO YEARS AFTER PLANTING}

In December, 1929, I ordered a bill of peach and apple trees from you, as your books will show. All have surprised me very much-all of the peaches will bear from 5 to 8 fruits. The apples grew off and did well. The Yellow Transparent has 3 apples. Also the Red June will have four or five apples. This seems unusual for apples.

J. Thos. Hall, Nacogdoches, Texas. May 3, 1931. 


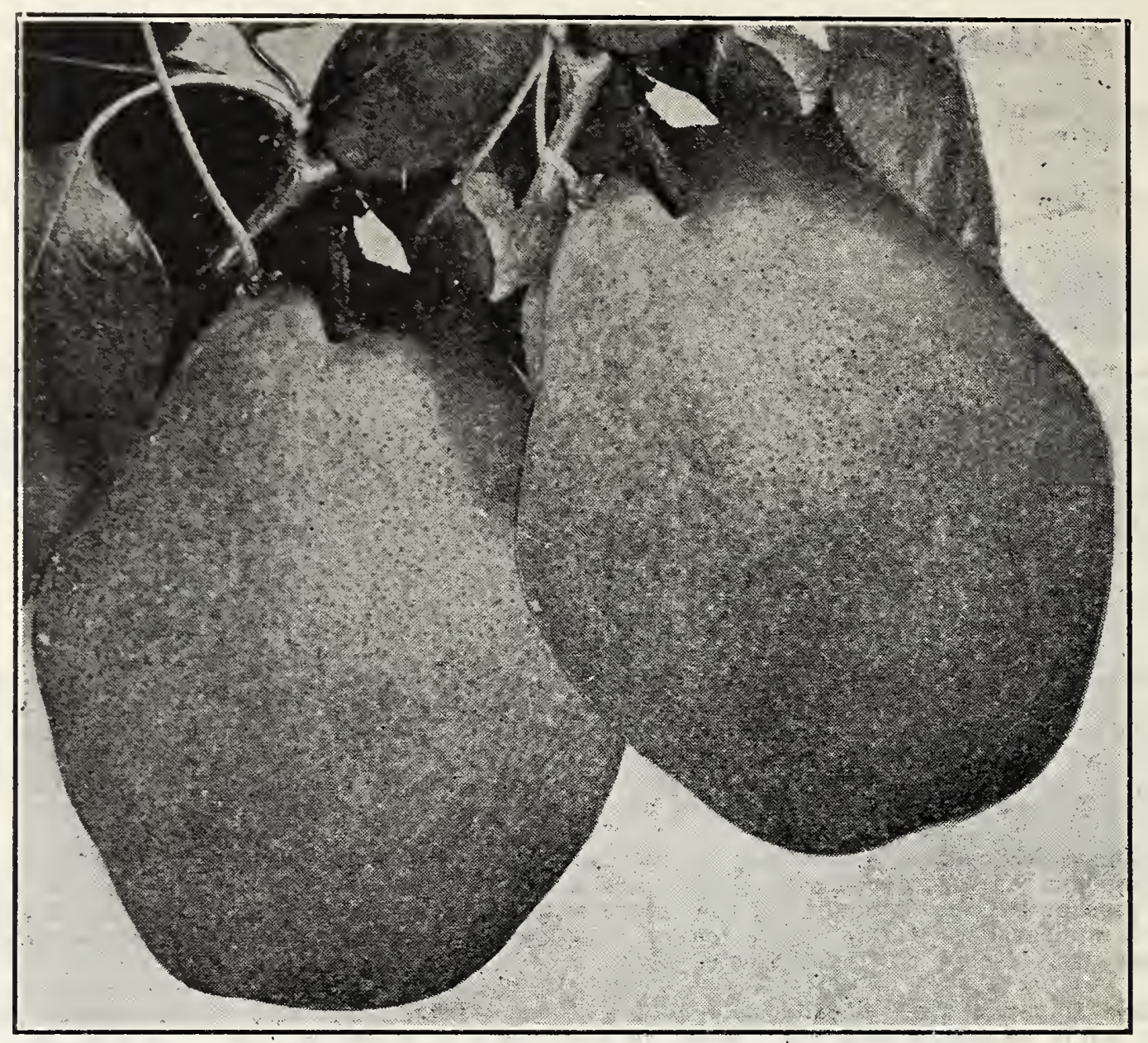

\section{Pear Trees}

(Price List on Pages 43 and 44)

\section{FOR CHOICE COLLECTION OF PEAR TREES DELIVERED FREE, WITH TREE FOOD AND BOOK, SEE PAGE 5}

Early Flarvest. A large, yellow, pink-cheeked Fear of good quality. Exceedingly handsome variety in both tree and fruit. Ripens early in June. 'The extreme earliness, far ahead of all other kinds, gives it a high value for home use and for market.

Koonce. Similar to the Early Harvest. A very fine Pear, Ripens in June.

Early Green Sugar. A small green Pear of excellent flavor. Very productive, and said never to fail. Ripens in July.

Bartlett. A magniticent, large, juicy yellow Pear. Easily King of all August rears. A variety of very high value indeed that should be planted in every orchard and in every home garden.

Seckel. A small, brown, russet-red Pear, popular for its sweet tlavor. Kipens in late August.

Japan Golden Russet. An extra-fine variety for home use and market sales.

Le Conte. Strikingly beautiful in tree and fruit. Immensely productive of very large, yellow Pears of tine quality. September. Most universally successful of all Pears except Kieffer.

Garber. Of Oriental origin, like Le Conte and Kieffer, and like them, amazingly prodactive. A large, yellow, pink-cheeked Pear of excellent tlavor, rich, juicy and luscious. Ripens late September.

Kieffer. The largest, handsomest, and most productive of all Pears. A huge lump of gold, brilliantly tinted red when ripe. Ripens in late Uctober and November and keeps well all winter. 'Trees easy to live, quick to grow off, and early to bear. We know single trees of Kieffer that bear over ten bushels year after year without ever failing. Good quality when thoroughly ripe. 'I'his superb fruit, the king of all late Pears, has been discovered to have one immense advantage over all other Years, and indeed of most other fruit-the tree is proof against San Jose scale. 


\section{Japanese Plums}

\section{(Price List on Pages 43 and 44)}

This magnificent Plum is a genuine revelation to a person who has never seen it. Its large size, exquisitely beautiful coloring, and immense productiveness is astonishing. At fruiting time the trees are simply piles of tlaming, red plums. 'l'he delicious tlavor and wholesomeness of the fruit is as striking as its qualities. It is entirely free from the unwholesome qualities of the common wild Ylums. Children and invalids eat the best sweet varieties not only with safety but positive benefit. After testing all varieties in our trial orchard, we have selected the following as the tinest and best of this glorious family. F'lne Plums, like tille peaches, sell well at home or on the large market. 'I'he trees are beautiful ornaments for yard or garden.

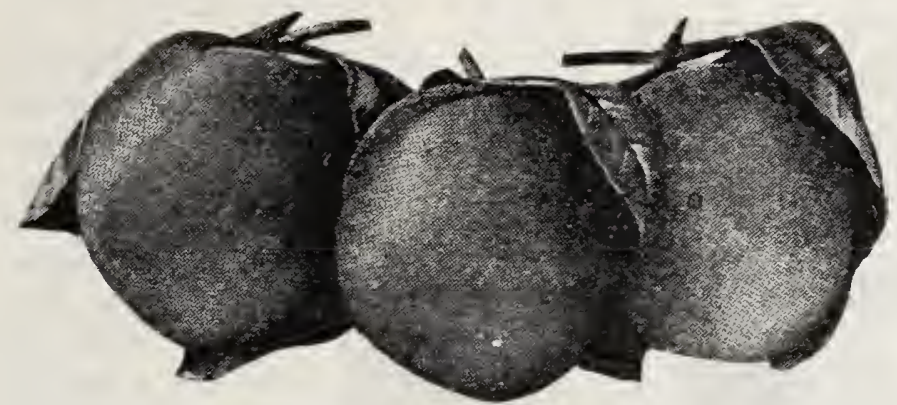

Red June. 'l'he earliest of the Japan group of plums, ripening in June. Size very large, color tlaming red, quality very gocid. A sure and exceedingly heavy bearer. Valuable for home use or market, on account of its earliness, beauty, and general excellence.

Kelsey. A splendid Plum. Very large. Uolor, greenish-yellow, some times thushed with red. An excellent variety.

Mammoth Gold. Another yellow rlum and a very tine one.

Omaha. A splendid new Plum.

Abundance. Very large and of indescribable beauty. Closely follows Red June in ripen. ing, and remains in bearing a long time. Kightly named for its immense productiveness. Quality probably equal to any fruit that grows. Begins to bear on good soil at two years old, and rarely or never fails to produce a large crop of the finest fruit.

Climax. A cross between Japan and our native Plums, originated by Luther Burbank. Climax ripens soon after Red June. In size, in magniticent coloring, in enormous, amazing productiveness, and in exquisite flavor, it ranks with the best.

Ogan. One of the finest of these splendid Plums. Almost as large as a peach, and as delicious as any apricot you ever tasted.

Wickson. Cross between the Japanese Plum and our native Plum. Noted also for the beauty of its tree growth and fruit and for the excelience of its immense crop of fruit. Ripens soon after Abundance.

Apple Plum. Resembles an apple in appearance. A very large rlum of excellent flavor. Ripens in July.

Hale. A very large and yellow Plum with a peach flavor. Early August.

Chabot. Another large, red and yellow Plum of good quality. Ripens in late August.

Wild Goose. A large, purple-red Plum of native origin. Well known for its productiveness and good eating qualities. Early June.

Shropshire Damson. The finest and most productive of all the Damson family. Grown chiefly for preserving, for which it is unequaled.

\section{APRICOT}

Early Golden. A very fine, deep yellow Apricot.

\section{GIVEN ADDED CONFIDENCE AFTER RIDING THROUGH OUR NURSERY}

It was my pleasure to drive through your nursery in September (that is via the highway) and what I saw gave me added confidence in everything you have always said about your merchandise. It was a grand sight and I enjoyed it thoroughly. Wanted very much to stop but ny time was limited.

Roland R. Jones, Savannah, Ga. Jan. 8, 1931.

\section{PLANTS RECEIVED FROM US ARE THE TALK OF ALT WHO SEE THEM}

My apple trees, grapevines, and peach trees I got from you are the talk of all who see them. I am "full up'" on vines and trees-no more space to plant anythingbut will always speak a good word for the Continental Plant Company and their splendid tree supplies.

Rev. John A. May, Montevallo, Ala. March 17, 1931.

\section{CUSTOMER FOR MANY YEARS; FINDS OUR COMPANY RELIABLE IN} EVERY WAY

I have been a customer of yours for many years, and have always been highly pleased with the trees that I received from you. Your trees are just what they are represented to be, and they ccme true to name. I have always found your Company reliable in every way, and it is a pleasure to deal with you.

T. Ben Kerr, Piedmont, Ala. Dec. 12, 1930.

Please send me catalogue of strawberry plants and other nursery stock. Have just eaten some fine strawberries from plants bought from you.

Sam Craig, Fort Valley, Ga. May 1, 1931. 


\section{Cherry Trees}

\section{THE COMBINATION TREE-FRUIT AND SHADE}

Hew trees combine the useful and ornamental in as large degree as the Cherry. 'I'hey make an exceedingly handsome shade tree, worthy of a place in every yard or lawn. Ur they can be grown in any spare or waste space or corner, no matter how rough and stony, needing no cultivation after the tirst two or three years, and they are very long lived.

(Price List on Pages 43 and 44)

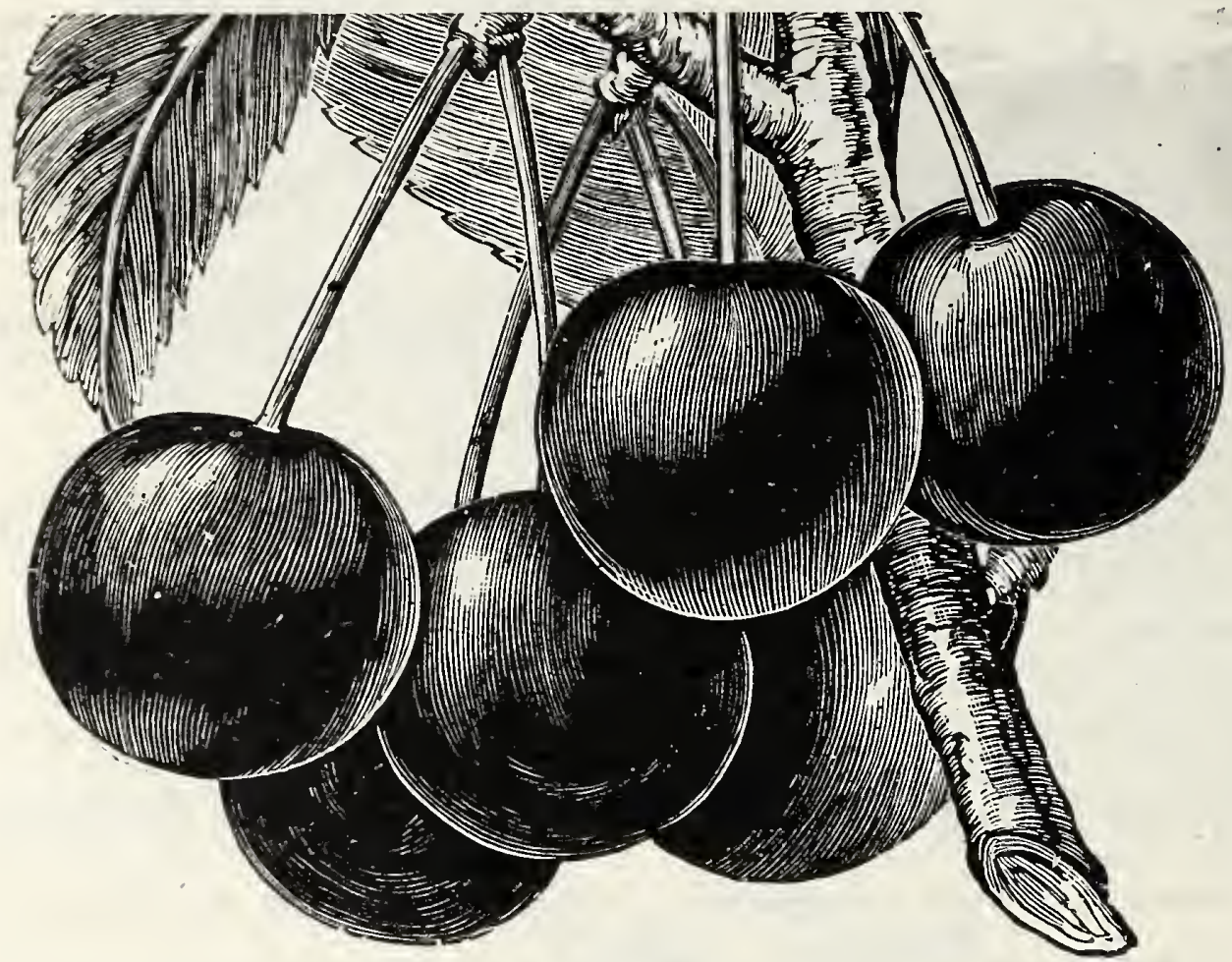

Earl g Purple. A large, luscious U h e r r y, rich purple in color. Kipens here at the very beginning of May with the earliest strawberries. Its fine f 1 a $\nabla$ or makes it valuable for home use, and its size and earliness for market.

Black Tartarian. Another splendid large black Cherry of same liabit as Early Purple. Ripens in $M$ a y. A standard Cherry, mos t uniformly successful of all.

Governor Wood. A very handsome, large yellow Cherry of sweet, delicious tlavor.

Short-Stem May. An old standard variety whose tine quality and unsurpassed productiveness makes it immediately popular.

Rockport. A tine, red Cherry of tirst-rate quality, belonging to the same class as the preceding varieties.

May Duke. A very tine, large, dark red Cherry that succeeds and bears heavily over a wide region.

Early Richmond. A tine, large Cherry of brilliant red color.

English Morello. An improvement on the popular old Morello.

Yellow Spanish. Large; Pale Yellow, with light red cheek; firm and delicious.

\section{Everbearing Mulberry Trees}

These trees are exceedingly rapid growers and come into heavy bearing in three or four years. 'Then for months they continue to ripen large quantities of fine, large fruit, good to eat and of the highest value for poultry and hogs, which can be penned around trees and kept fat and healthy. No raisers of chickens or poultry of any kind can afford tc be without them if they cost $\$ 5$ a tree.

This valuable tree should be planted where hogs or poultry can be penned under them. They do well anywhere, being exceedingly hardy. 'They will thrive in low places near streams, where water can be penned with them for the pigs and poultry.

\section{OUR GUARANTEE}

broad guarantee given on page 35 . any nursery in the country.
Every tree, plant. shrub, bush, etc., etc., offered by us is strictly first class and is guaranteed to satisfy the purchaser. Note the It is, we believe, the broadest guarantee given by 


\section{SHADE AND DOLLARS FROM THE SAME TREE}

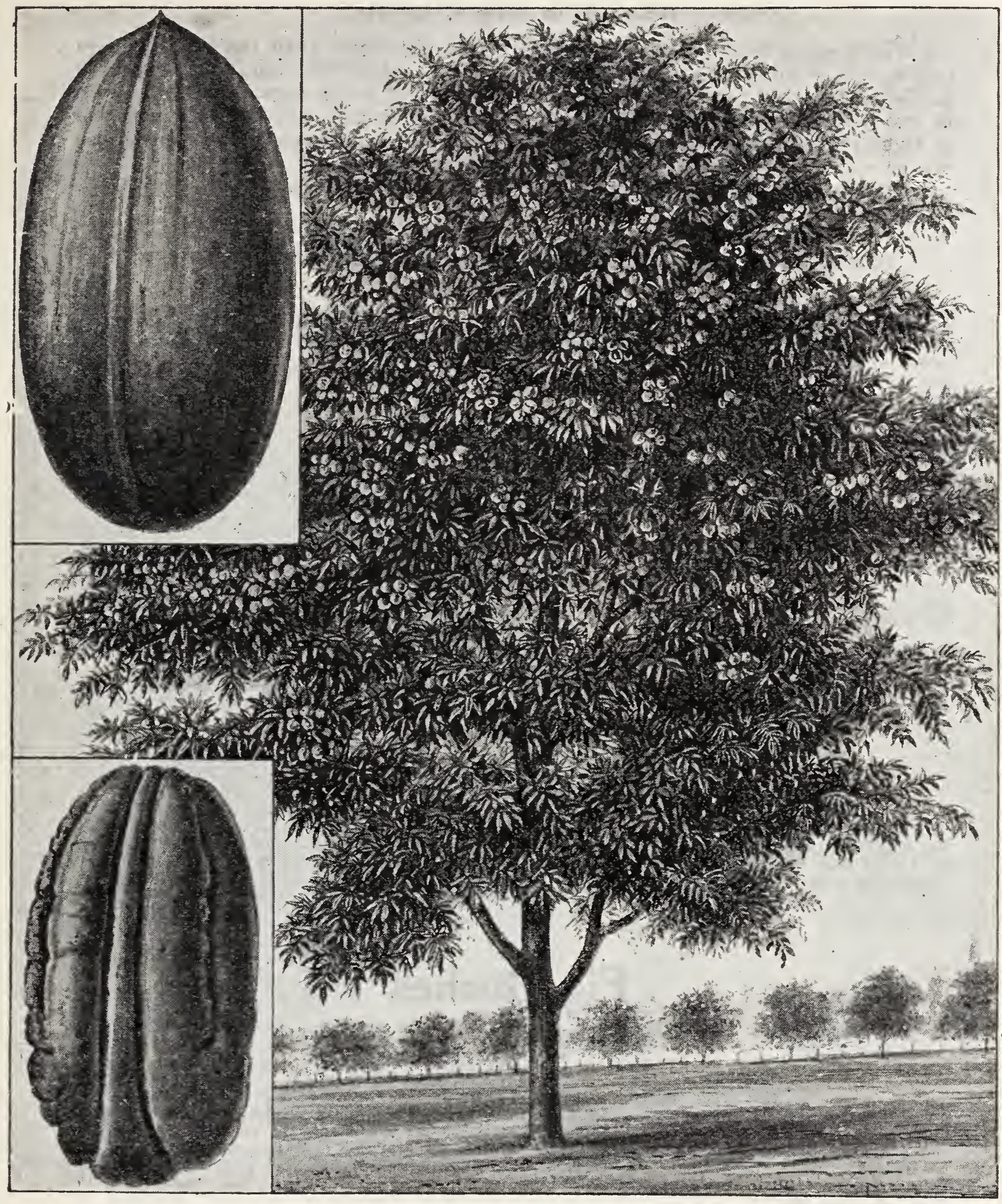

\section{A TYPICAL FIVE-YEAR-OLD PECAN TREE}

This illustration shows a five-year-old tree which was photographed in our own orchard. It was then fifteen feet tall and it bore ten pounds of large nuts which were worth at that time fifty cents a pound. (Now they are much more valuable.) 


\title{
Paper-Shell Pecan Trees
}

\author{
(Price List on Pages 43 and 44)
}

The demand for this splendid nut is increasing faster than the supply. Trees thrive in any soil and climate that cotton does. Set 50 feet apart each way, 20 to the acre, with a peach tree between each way, 100 to the acre, profit will begin in two years and rapidly increase. In four years Pecans will begin to pay and in eight years peach trees, after paying all expenses and leaving handsome profit, can be cut off. We recommend the Stuart Pecan as best.

Pecan tree sent with taproot eut back so as to force branching, as recommended by successful growers.

\section{DIRECTIONS FOR HANDLING AND TRANSPLANTING PECANS}

Take great care in preventing the roots of trees from becoming dry by being exposed to the weather. Keep the roots moist and covered at all times. When taking the trees to the field for setting they must be carefully covered with moss, wet sacks or something similar, to protect them from drying out. This is important. Only one tree should be removed at a time, and this set at once in the hole previously dug. Tine hole must be at least two feet wide and of proper depth. Cut off the ends of all bruised or broken roots. Use a sharp knife for this; do not use an axe or hatchet. It has been practically demonstrated that it is advisable to cut off part of the taproot, as this causes the roots to throw out laterals. This will allow the tree to receive food, and at the same time affords it a firmer hold upon the land. Place the tree in the hole about two inches deeper than it originally stood in the nursery row; fill the hole about half full with well pulverized top soil in which there is a proper proportion of well-rotted stable manure. If this is not available, use the proper amount of high-grade fertilizer or bone meal. This must also be thoroughly mixed with the soil.

Pack the earth well about the roots of the trees, the firmer the better. Fill up the hole and pack the dirt well, but leave at least two inches of loose soil on top. If the soil is very dry, some water should be poured about the tree when the hole is partly filled. When the trees are more than four to five feet in height, the top should be cut back within four feet of the ground. Do this after the tree is planted. Be careful not to break the eyes oft the tree in handling. Keep them well cultivated and properly pruned.

Schley. A large nut and a very early and prolific bearer.

Stuart. Nut large to very large; $1 \frac{3 / 4}{4}$ to $2 \frac{1}{8}$ inches long; oblong; shell medium thick. ness, and of very good cracking quality; kernel full, plump, of best quality; tlavor rich alla sweet; a good grower; heavy bearer; excellent.

\section{RHUBARB (Pie Plant)}

This is exceedingly easy to grow and, like asparagus, once set, lasts for years. It is much earlier than asparagus. The edible parts are the stems of the long leaves. These can be cut as fast as they come in the spring, and stewed with sugar, make most delicious and wholesome pies, tarts, and sauces. Stewed rhubarb also makes a most excellent breakfast dish. In all respects it may be used in the place of cranberries. (See Price List, pages 43 and 44.)

\section{Fig Bushes}

\section{FOOD AND MEDICINE IN ONE}

This luscious and mildly laxative fruit-old almost as time itself-the fruit that re freshed and nourished the men who made history in Bible days, is about the easiest of all to grow. After the first year or two it needs no further attention unless you are far enough north for the branches to be winter-killed. With a few cedar or pine bushes stacked around it as cold weather sets in, it can be fruited much farther north than is usually believed. In the southern and central parts of the country (except in the mountainous portion of the central parts, where it will need protection) it thrives without attention, growing into 10 -foot trees and producing amazingly of its delicious and wholesome fruit - ten bushels to the tree has been known.

No southern home is half complete without its Fig bushes and Scuppernong vines. We grow the Brown Turkey Fig, which we find to thrive and bear heavily over a wider range of country than any other kind

Brown Turkey. Large; skin dark brown; flesh red; very delicious. One of the hardiest and we consider the best variety on the market.

Brunswick. Very large, purplish black. A good quality and a good bearer.

Celestial. Medium size, pale violet. A sweet and excellent fig.

Green Ischia. Medium size, rosy red. A variety of good quality.

Price, 50c each; $\$ 4.50$ per dozen. 


\section{Grapes}

(Price List on Pages 43 and 44)

Scuppernong. The most wonderful of all the Grape family. In lusciousness of flavor not surpassed, and hardly equaled by any Grape or fruit that grows. Immediately prolitic, and needing no attention after the tirst two or three years except to provide a frame or arbor for the rapidly spreading vines to grow on and be supported. There is scarcely any limit to the age to which it lives, or to the quantity of Grapes a vine will bear. 'The original vine found on Roanoke Island, N. C., by the first English settlers on this continent is said yet to thrive and bear. I have seen single vines that I am sure were loaded with over twenty-five bushels at one time.

Thomas (Scuppernong Family). Dark reddish purple. Fruit is sweet and tender.

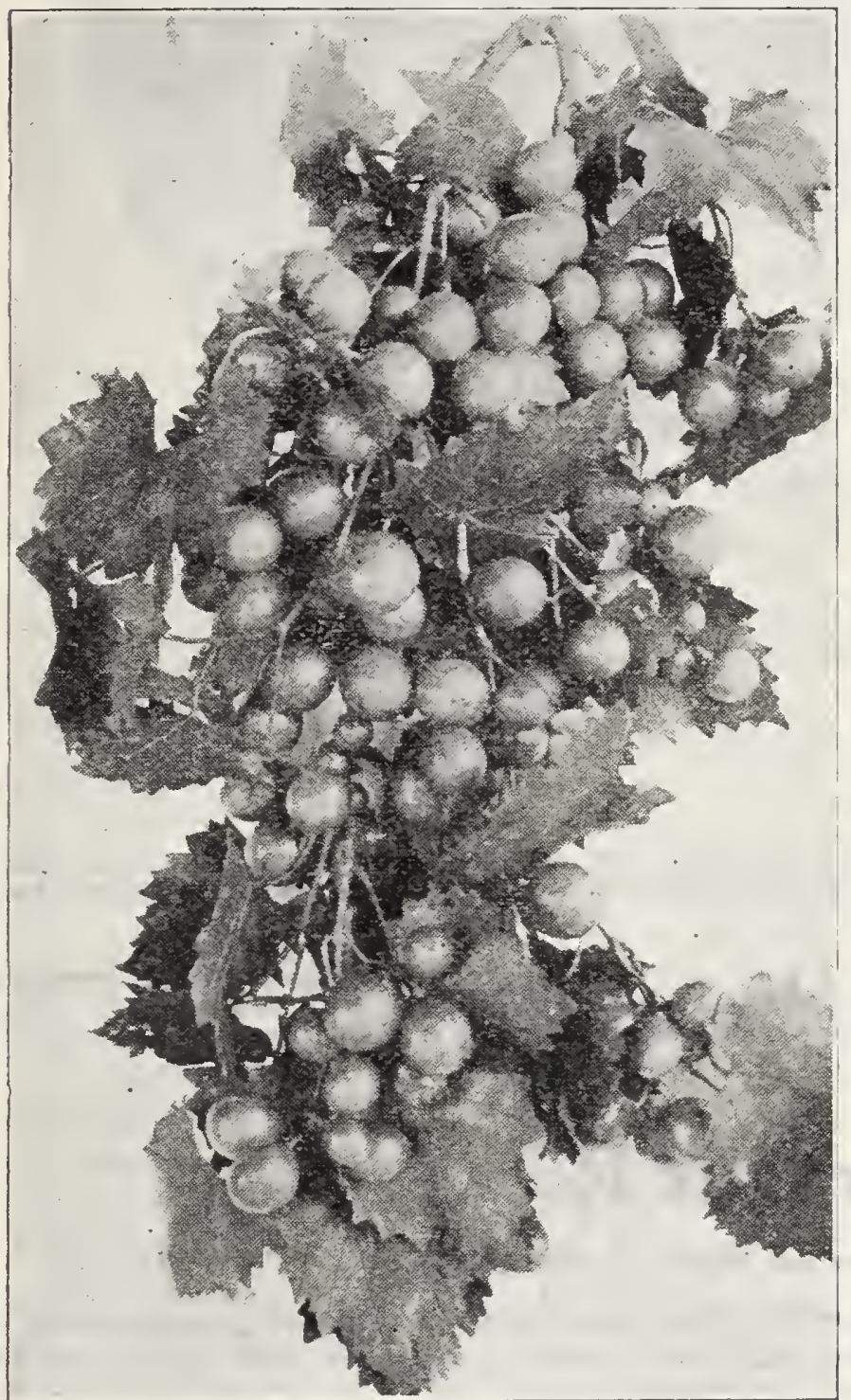

Mish (Scuppernong Family). Black. Medium-sized berries, which are delicious, rich and of splendid flavor.

Flowers (Scuppernong Family). Black. Bunches have from fifteen to twenty-tive berries, which are of delicious sweet Havor. Ripe about Uct. 1, approximately a month later than Scuppernong.

James. A black Scuppernong, but larger, aud by some considered even more luscious and better in all re spects. Similar in growth and fully as heavy a bearer. As good for wine as for the table. Both of these Grapes seem immune from all diseases. Even in damp low places they thrive wonderfully. Both make excellent wine.

\section{Bunch Grape Vines}

'l'he Grape-vines take up such little room and yield such a heavy crop of the most delicious and wholesome fruit that no garden should be without them They can be planted along the fence or on each side rif the garden walk. If so planted and trained over the walk in a trellis they bear heavily. the Grape-vines completely rooting the leafy arch.

'The bunch Grape is noted the world over, not only for its deliciousness. but also for its wonderful wholesomeness. People who can eat no other fruit, except perhaps the peach and Never-Stop Strawberry, eat Grapes, not only without harm, but often with benefit to their health. In fact, the Grape cure is a well-recognized system of dietetics in some countries.

Moore's Early. A large, dark purple, very early Grape of excellent quality. In fact, we tind it to be the very earliest good and most reliable Grape that we have ever seen; prolitic bearer; succeeds everywhere.

Concord. A fine, purple Grape, closely following Moore's Early, and giving a succession of Grapes for a long while. Concord is an immense bearer of most excellent and wholesome fruit. Great also for wine. A standard Grape everywhere.

Delaware. A small red Grape, but borne in large bunches. Famous for its delicate Havor and as a dessert Grape.

Niagara. 'The best, most popular and most generally successful white Grapes. A truly excellent variety.

Ives. Clusters and berries are of medium size; dark purple; sweet and pulpy, with some foxiness. Should hang on the vines a while after colcring.

Catawba. An excellent table and wine Grape with large, round berries, rather closely set in clusters of good size; when fully ripe they are a dark copper-color, with a sweet, rich musky flavor.

Worden. A seedling of Concord, but larger in bunch and berry, of better tiavor, earlier, as hardy and healthy in every way, producing fine crops that command good prices. A superior Grape that deserves to be a market leader. 


\title{
GRAPES-Continued
}

Campbell's Early. Black. Clusters and berries large; flavor quite sweet and rich. A good keeper and one of the best early varieties.

Moore's Diamond. Yellowish white, tinted with yellow when ripe. Large bunches; berries set elose together on long stem. Vines are hardy, vigorous, and produce abundantly.

Wyoming Red. Hardy, early, productive, good sized in bunch and berry; brisk, sweet flavor.

Isabella. Color black. Vine strong grower, large bunches. Midseason.

Lindley. Midseason. Quality excepionally good. Vine hardy. Fruit red.

Agawan. Fruit purplish red, large, rich and sweet: keeps well; vine vigorous. Ripens soon after Concord.

Pocklington. Clusters large, berries yellowish green, flavor rich and sweet, ripens later than Concord. Vine hardy and productive.

Salem. Fruit early, rich and high quality, dark red.

Martha. White, turning to pale yellow when ripe; skin thin; flesh very sweet and juicy; bunches and berries medium. A little earlier than Concord.

Lucile. Recommended where an extra hardy grape is desired, and where the season is short. Quality considered very good.

\section{NEW VARIETIES}

Caco. A new variety which is prov. ing to be one of the best. It is winered with abundant bloom; the berries are very large; bunches medium in size, compact and of good form. Ripens almost with Concord, possibly a few days earlier, but so rich in sugar it is excellent in flavor two weeks before fully ripe. $75 \mathrm{c}$ each.

Hubbard. Without any question, the finest early black grape. It has the most delicious Alavor of any grape we have ever tested. Berry extra large, jet black with a thin skin. Seeds very few and small, which separate freely from the tender pulp. $75 \mathrm{c}$ each.

\section{Asparagus Roots}

\section{(Price List on Pages 43 and 44)}

No garden is complete and no housewife has justice done her unless provided with a bed of this excellent and most wholesome vegetable. Coming as it does, next to the earliest of vegetables (rhubarb being the earliest), its value is very great. It is most beneficial in bladder and kidney troubles. A bed once established will give an abundant supply for a generation.

\section{Horse-Radish}

\author{
Thrives in Any Fence-Corner or Spare Space
}

It is easy to grow as a weed, and every good housewife knows its great value in the making of sauces and seasonings. Once used in pickle it will never be gone without. Horseradish sauce is one of the chief appetizers of the golden old-time Southern cuisine. It is also one of the few sauces or condiments that is pronounced by the best authority to be perfectly wholesome. A dozen plants will supply a large family for life-time and it grows and multi. plies very fast. 50c per dozen. 


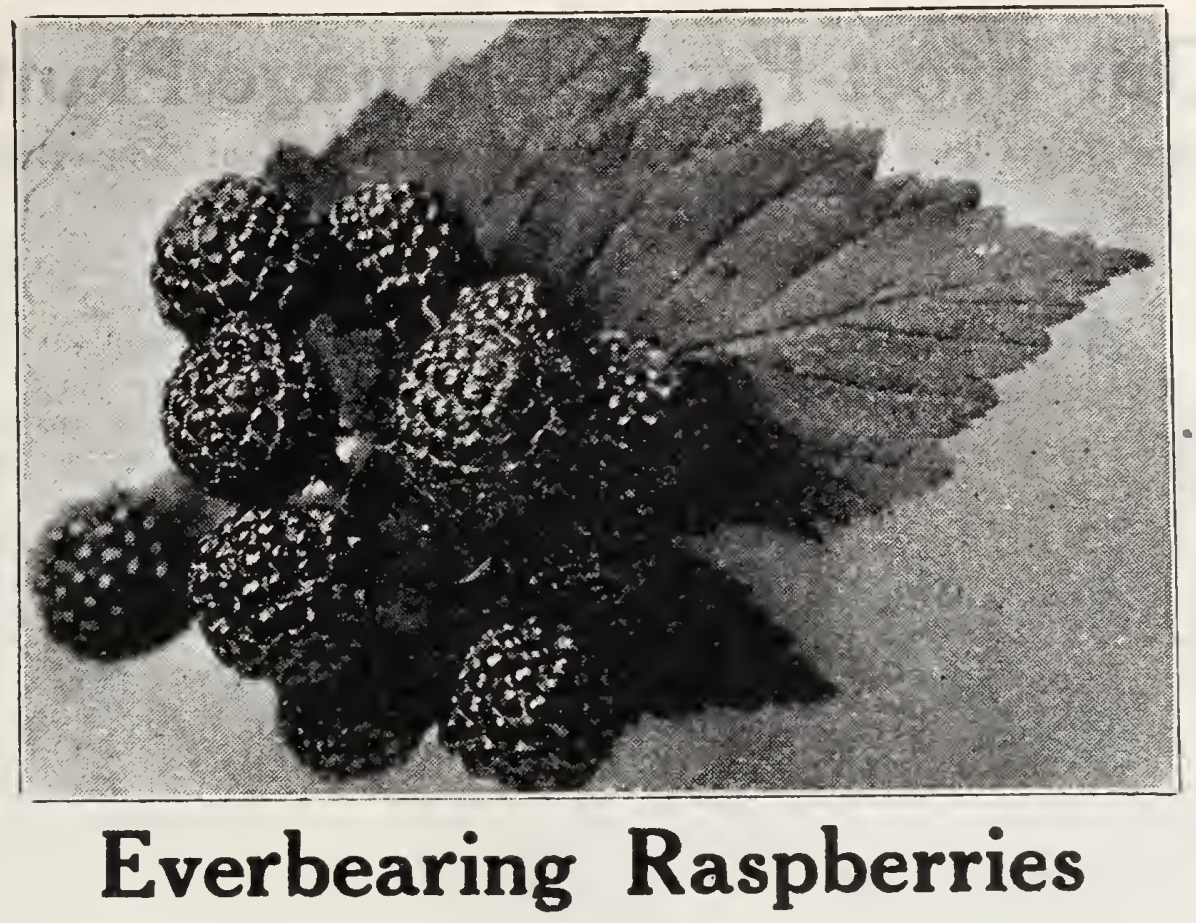

We do not list separate varieties of Everbearing Raspberries because not any of them seem to be suited to all localities. We have in stock the St. Regis and other valuable varieties, and if you specify Everbearing Raspberries on your order we will send the sort best suited to your vicinity.

(Price List Pages 43 and 44)

\section{Spring-Bearing Raspberries}

Cuthbert. The best red kind for the South. Fruits are always large and sweet.

Cumberland. Berries are large and handsome; plants quite hardy and productive.

We can supply other varieties.

\section{DEWBERRIES}

Lucretia. The one best variety; larger, and with a better flavor than blackberries.

\section{BLACKBERRIES}

Early Harvest. Medium-sized berries of excellent quality. The canes ar $\theta$ most prolific.

Himalaya. Very large fruit of Dewberry type, juicy and excellent flavor.

\section{OUR QUICK SERVICE CAUSES TREES TO IIVE}

Last spring I bought some trees from you and all of them lived. At the same time I bought forty trees from another nursery and all of them died. The order was given the same day to each house, but the other nursery delayed a month in shipping their trees and by the time they came here the drought had set in and all of the trees died, while you shipped yours a month earlier and your trees lived.

B. T. Clark, Tupelo, Miss. March 30, 1931. CUSTOMER FOR 25 YEARS AND STILL RECOMMENDS US

Yes, I am an "old customer." I have been sending you my orders for 25 years or more. I have sent you many customers, not only from Norfolk and Portsmouth, but from other places as well. I never miss an opportunity to recommend you for as I frankly told, one can depend upon getting what they order. October 23,1930 .

\section{ALWAYS FINDS STOCK AS WE REPRESENT IT}

Received my strawberry plants yesterday and thank you for your promptness. Plants. are lovely, came through nice and fresh. Gave your name to our County Agent the other day and told him that any one that bought from you would be pleased. Have been buying from you for years and always find things just as you represent them. Hope you get lots of orders from this section. Will always. speak a word for you when I can.

Mrs. D. S. Farrar, Lake Village, Ark. October $31,1930$.

\section{SHIPPED PLANTS OCTOBER 31; GET BERRIES BY CHRISTMAS}

The plants are doing fine. Most of them in bloom and will have berries by Christmas, M. E. Clarke, Daytona Beach, Fla.

Dec. 2, 1930. 


\section{Our Frost-Proof Cabbage Plants}

\section{Will Mature Heads Two to Three Weeks Earlier Than Your Home-Grown Plants and Double Your Profits. Why?}

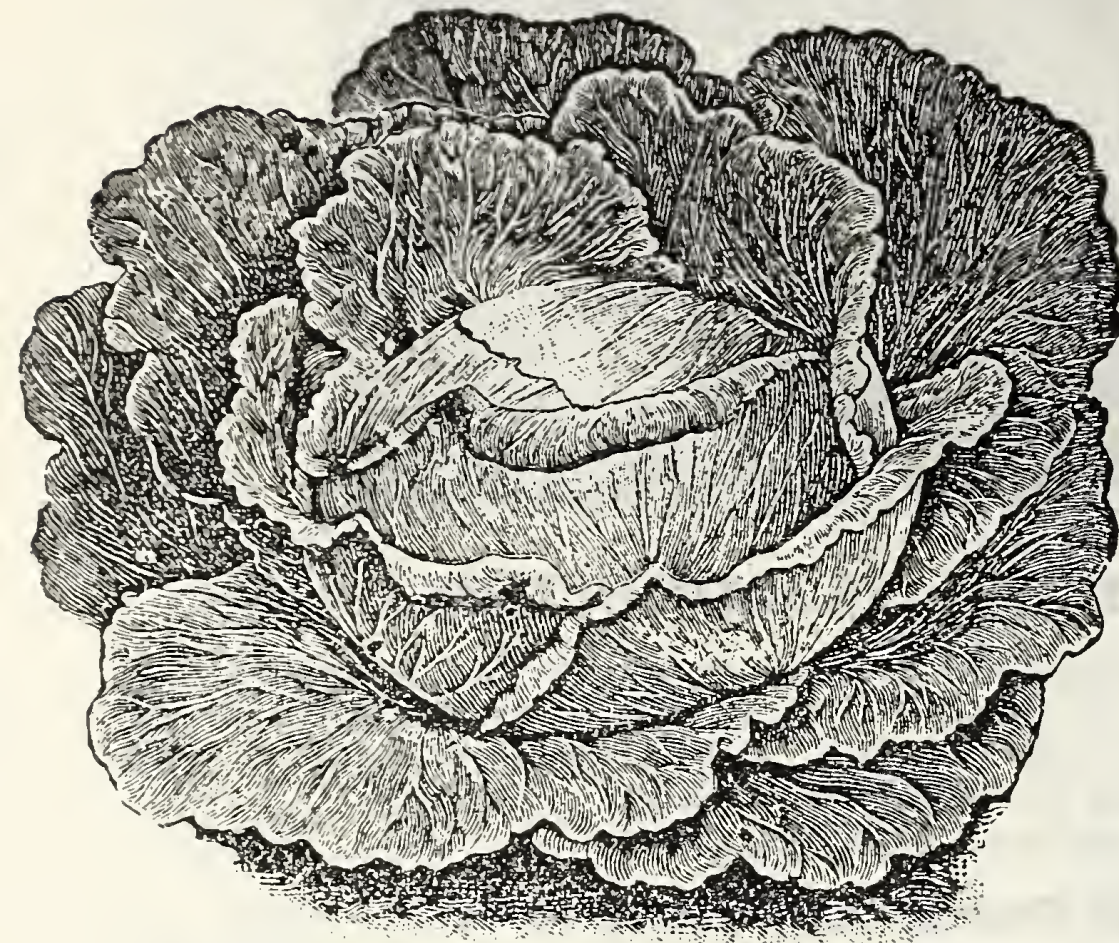

There are a number of islands along the seacoast of South Carolina, where the soil and climatic conditions are just suited for growing tough, hardy cabbage plants during the Winter and early Spring. The plants make a slow - at steady growth, until at eight o ten weeks of age they are very ough and hardy, the buds are purple and the outer leaves a reddish brown. When in this condition they can be shipped to territory farther north and be planted $n$ the open ground a month to six weeks sooner than the home-grown hot bed or cold frame plants. These F'ROST-PRUOF CABBAGE PLANTS will stand a temperature of 20 degrees above zero without injury. The land freezing, or the plaris being covered with ice, sleet or snow after they are planted will not injure them, providing temperature does not go below 20 degrees above zero.

The top of the plant does not grow until your regular Spring weather opens up, but the roots grow from the time they are planted, and just as soon as spring weather starts the established root growth assimilates the fertilizer in the soil, the plants grow very fast, maturing headed cabbage two to three weeks sooner than you can mature them from hot bed and cold frame plants. You know what the difference in protit. will be if your crop is matured and marketed before the general crop from home-grown plants is matured.

To get the advantage of these frost-proof Cabbage Plants they must be planted a month or six weeks earlier than you would plant home-grown plants. We fill orders from December 1st to May 1 st.

The plants when received will be somewhat wilted and have a hard, stunted appearance, which will be disappointing to persons who have never used these plantscbefore. Regardless of appearance, they will produce the crop results.

\section{Varieties: Early Jersey Wakefield, Charleston Large Type Wakefield, Copenhagen Market, Succession and Early Flat Dutch}

Prices by Parcel Post, postage paid. In lots of $100,200,300$ or 400 plants at $50 \mathrm{c}$ per 100 plants; 500 plants for $\$ 1.60 ; 1,000$ or more at $\$ 3.00$ per 1,000 plants.

Orders are filled by the 100 , not 250 or 350 . These prices are $f(o r$ even quantities of one variety to package; if you ordered 200 of one variety and 300 of another variety you would pay at the 100 rate.

Prices by Express, buyer paying express charges. In lots of 1,000 to 3,000 plants at $\$ 2.00$ per 1,$000 ; 5,000$ or more at $\$ 1.50$ per 1,000 . Plants packed for express shipment, 1,000 or 2,000 plants of a variety to package, they weigh about 25 pounds per thousand plants, packed for shipment.

\section{Order Early to Get Plants Delivered in Time}

When we receive your order for these plants, we have to forward it to our growing station, which takes several days. Plants are shipped direct to you from growing station. Plants cannot be pulled or shipped when beds are wet. We sometimes have a week or ten days of continued wet weather, which prevents shipment. If you do not receive your plants as soon as you expect them, you will know that weather prevents shipment. Send your order two to three weeks before you expect to set the plants and you will get them on time.

\section{ONE OF THE HUNDREDS OF CABBAGE PLANT TESTIMONIALS} WE HAVE ON FIIE

I want to buy some cabbage plants. I have bought plants from several firms, but your plants are much nicer and I get lots better results from your plants than any others I have bought

Owen Webb, Okeona, Ohio. Feb. 23, 1931. 


\section{Flowering and Other Shrubs}

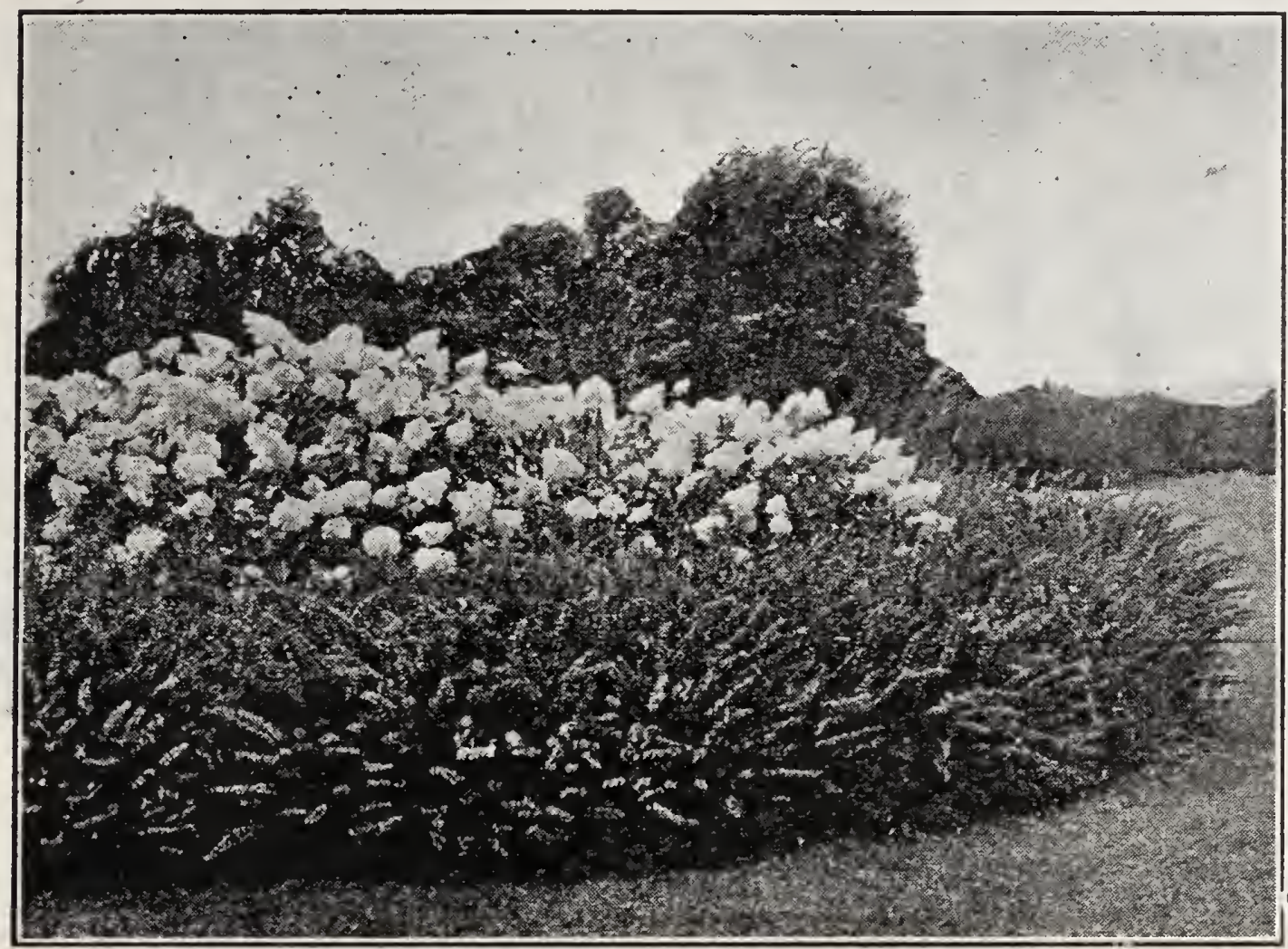

\section{All Shrubs Two Years Old and Strictly First Class}

Almond, Flowering (Pink). A beautiful, early blooming, dwarf shrub of shapely, com pact growth, especially valuable because of the profusion of flowers which come very early in the Spring. Price $75 \mathrm{c}$ each.

\section{ALTHEA (Rose of Sharon)}

The Altheas are fine, free-blooming shrubs, of easy cultivation and desirable on account of their late summer-blooming.

Ardens. Bluish purple; a distinct color and good variety, 50 cents each.

Duchesse de Brabant. Flowers large; very double, of reddish lilac color. Une of the best varieties. 50 cents each.

Jean d'Arc. Double; pure white. 50 cents each.

White with red centers. Single flower. 50 cents each.

Pink. Finest pink, single flower. 50 cts. each.

Purple. Double flower, purple bud. 50 cents each.

Variegated. Double pink and white mixed color. 50 cents each.

Berberi Thunbergii (Japanese Barberry). The best deciduous Hedge Plant. It is beau. tiful throughout the year. Its abundant crop of bright red berries makes it as attractive in the fall as in the summer. It requires no attention, except occasional cutting back of a few straggling branches. Hardy of easy culture, and will grow in any soil or situa. tion. During the growing season the foliage is attractive, because the new growth, lightgreen in color, is in sharp contrast to the foliage of the old, which is a glossy, dark, rich green. Japanese Barberry can be used with entire safety. Price, 40 cents each. $\$ 25.00$ per 100 . Select three-year plants.
Red Teaf Barberry Similar in all respects to the green-leaved Japanese Barberry, except foliage of this new variety is of a rich, lustrous, bronzy red. As the season advances the foliage becomes more brilliant and gorgeous and changes to vivid orange, scarlet and red shades. Followed by brilliant scarlet berries which remain on the plant the entire winter. Price, 12.15 in., $\$ 1.00$ each.

\section{BUDDLEIA}

Butterfly Bush. Rapid grower. Long spikes of lilac-like flowers during summer. Attractive to butterflies. Dies back in winter. Price 75 cents each.

Cherry, Japanese Flowering. The famous Flowering Cherry of Japan. The flowers are very large, pink, or blush, 30 to 40 feet. April 6 to 20 . $\$ 3.50$ each.

Cherry, Japanese Weeping. Weeping form worked on 4 to 6 feet stems, the pendulous limbs drooping to the ground. A beautiful object when covered with its rosy masses of bloom in early spring. 4 to $6 \mathrm{ft}$. $\$ 5.00$ each.

\section{CORAL BERRY}

Indian Currant. Like the Snowberry, except its leaves are smaller, and the smaller dull red berries cling along the stems, which droop beneath their weight. One of the show iest berry-bearing shrubs. Price $60 \mathrm{cts}$. each.

\section{CREPE MYRTLE}

A shrub growing to be 20 or 30 feet high Flowers are produced in large clusters and over a period of two or three months. 'l'his beautiful shrub or small tree, is distinctly soutliern in character, and should be used freely. Purple and pink, 2-3 ft., 50 cents each. 3.4 ft., 75 cents each. Ked and white, $2.3 \mathrm{ft} ., 75$ cents each. $3.4 \mathrm{ft} ., \$ 1.00$ each. 


\section{Flowering and Other Shrubs-Continued}

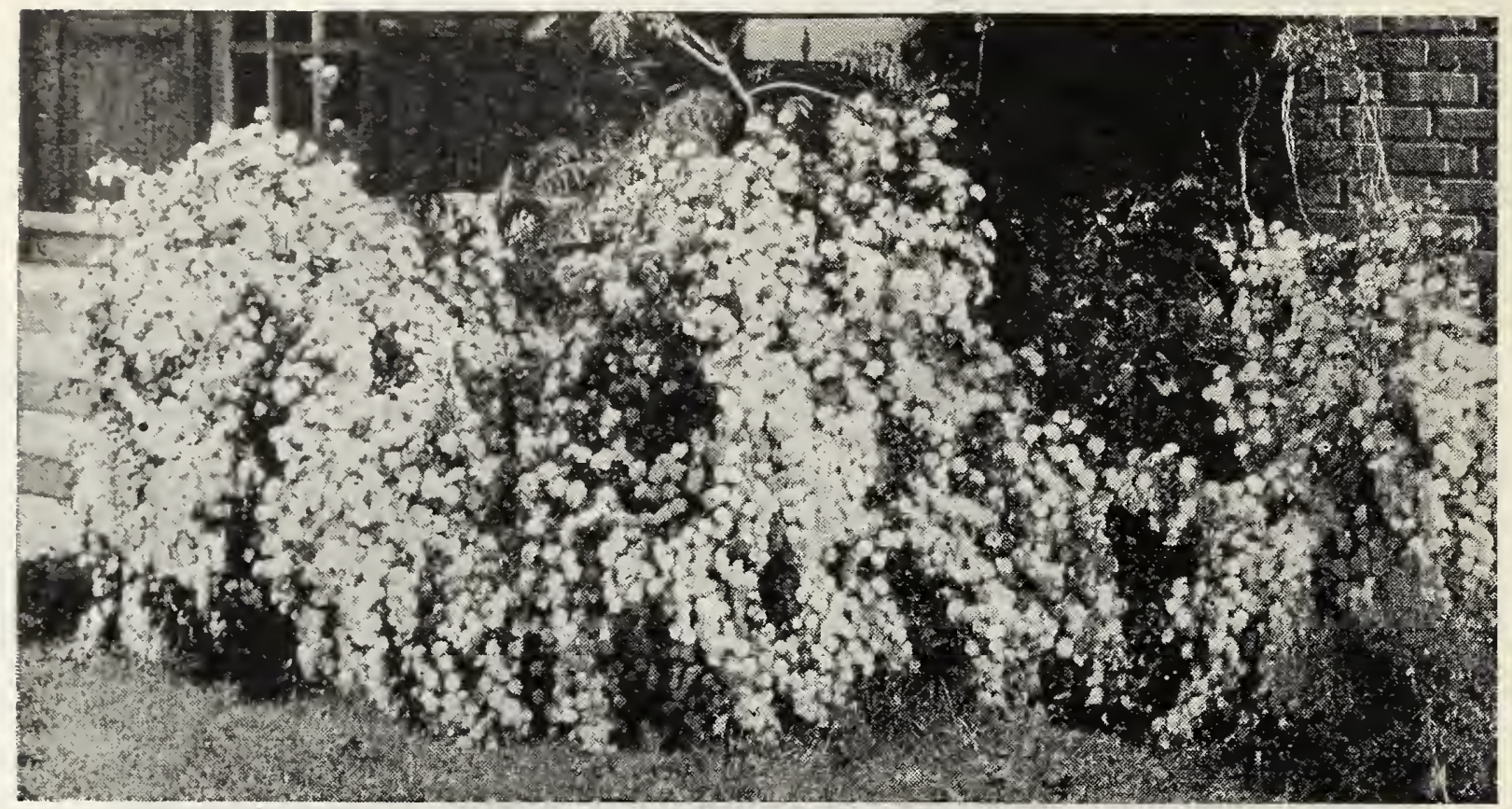

BRIDAL WREATH SPIREA

One of the Most Beautiful Shrubs

Desmodium (Lespedeza Bicolor). Small narrow leaves, and an over-supply of small lavender blossoms throughout september and early October, just when color is needed in border planting. 2 yr., 60 cents each.

\section{DEUTZIA}

Showy, profuse-Howering shrubs of easy culture.

Candidissima. Of recent introduction. Flowers pure white, large; very desirable. Price 60 cents each.

Crenata. Clear white flowers of large size. Plants thrive in almost any situation. Price 60 cents each.

Gracilis. Much used in foundation plantings about the house. Flowers white, single, and abundant. An especially good low-grow. ing plant. Price 60 cents each.

Fortunei. ' Large, double white flowers with yellow centers. Price 60 cents each.

Pride of Rochester. Origin, Rochester, N. Y. Large; double white Howers, back of petals being tinted with rose; excels most of the old kinds in Hower and vigorous habits; quite early and very handsome. Price 60 cents each.

\section{DOGWOOD}

Red Flowering Dogwood. Similar to the white flowering Dogwood, but the Howers are of a deep rose color. Early in the season it produces large quantities of Howers, which make it a most effective tree. $2-3$ ft., $\$ 3.50$ each.

Red Stem Dogwood. A spreading shrub with bright reddish purple branches attaining a height of 4 to $6 \mathrm{ft}$. Hlowers creamy white in dense flat-topped clusters. Berries white. Remarkably showy. 3-4 ft., 75c each.

Silky Dogwood. Another of the orna. mental shrubbery dogwoods. Flowers white, borne in panicles; fruit purplish-blue; branches red in winter. Gracefully spread. ing and thick set. Price $75 \mathrm{c}$ each.

White Flowering. Small growing tree, covered in early spring with a mass of large white Howers. Price $\$ 1.00$ each.

\section{FORSYTHIA (Golden Bell)}

Very early-flowering shrubs with bright golden flowers, conspicuous yellow bark. 'I'he drooping variety is valuable for covering large banks. Price 60 cents each.

Virdissima (Golden Bell). Erect, green barked branches, narrow leaves, and golden yellow Howers in March. Very good bloomer. Price 50 cents each.

Drooping. Growth, slender drooping; Howers yellow. Price 60 cents each.

\section{HONEYSUCKLF}

Red Tartarian. A beautiful shrub of up. right, medium growth, purplish red Howers appearing in late spring, followed by crimson fruit; highly desirable for beauty. Price 60 cents each.

White Tartarian. Same habits as above, only white. Price 75 cents each.

\section{FRENCH HYDRANGEAS}

Very attractive when used as tub plants for decorating steps or porch. Can be used in open ground if protected with burlap or straw during winter months. Cover a long blocming season and a beautiful shrub. Colors: white, rose, pink and blue. Price $\$ 1.00$ each.

\section{HYDRANGFA}

A group or shrubs, including some of the most showy plants known. Flowers borne in large panicles from July to September. Do best in fairly rich soil.

Arborescens. American Everblooming $\mathrm{Hy}$ drangea. Blooms from early May until the end of the growing season. The flowers remain pure white from four to tive weeks, then gradually change to a light green. Price 75 cents each.

Paniculata Grandiflora. The old reliable variety, producing its tlowers in large panicles often measuring six inches in diameter, in late summer and autumn. Price 75 cents each.

Hypericum. Gold F'lower. A beautiful dwarf shrub, attaining a height of 1 to 2 feet. Leaves dark green. Large, single golden yellow Howers, 2 inches in diameter are produced freely. Dies back in winter. June 15 to Sept. 1 . $75 \mathrm{c}$ each. 
Order Blank Write Name and Address Here; Your Order on Other Side. Order Blanil

CONTINENTAL PLANT COMPANY, Kittrell, North Carolina

Please Forward to

Name of Buyer.

Post Office.

State

Ship by

\section{County}

\section{Express Office}

On or About

(Mail, Express or Freight)

Date of Order.

On orders for trees for less than $\$ 1.00$, add 25 c extra to pay the packing.

All larger tree orders and all other orders packed free.

Please send Post-Office Order, Expreas Money Order, or bank exchange on New York, (to be had at any bank).

If we should be out of any varieties ordered, as sometimes will happen, especially when orders come late in the season, shall we send some other varicty which we know will suit your soil or climate as well or better?

Answer here.

If sure that we can substitute varieties which will give surer and finer crops with you than the varieties you have ordered, shall we do so or not?

Answer here.

Surplusage Premium! After filling orders we usually have a surplus of choice plants or trees leít. Surplusage Premium! If you will add $\$ 1.00$ to amount sent, we can afford to give you a great deal more (usually twice) its value in such choice plants or trees (as your order may be for), our selection as to varieties, though we will send only good ones.

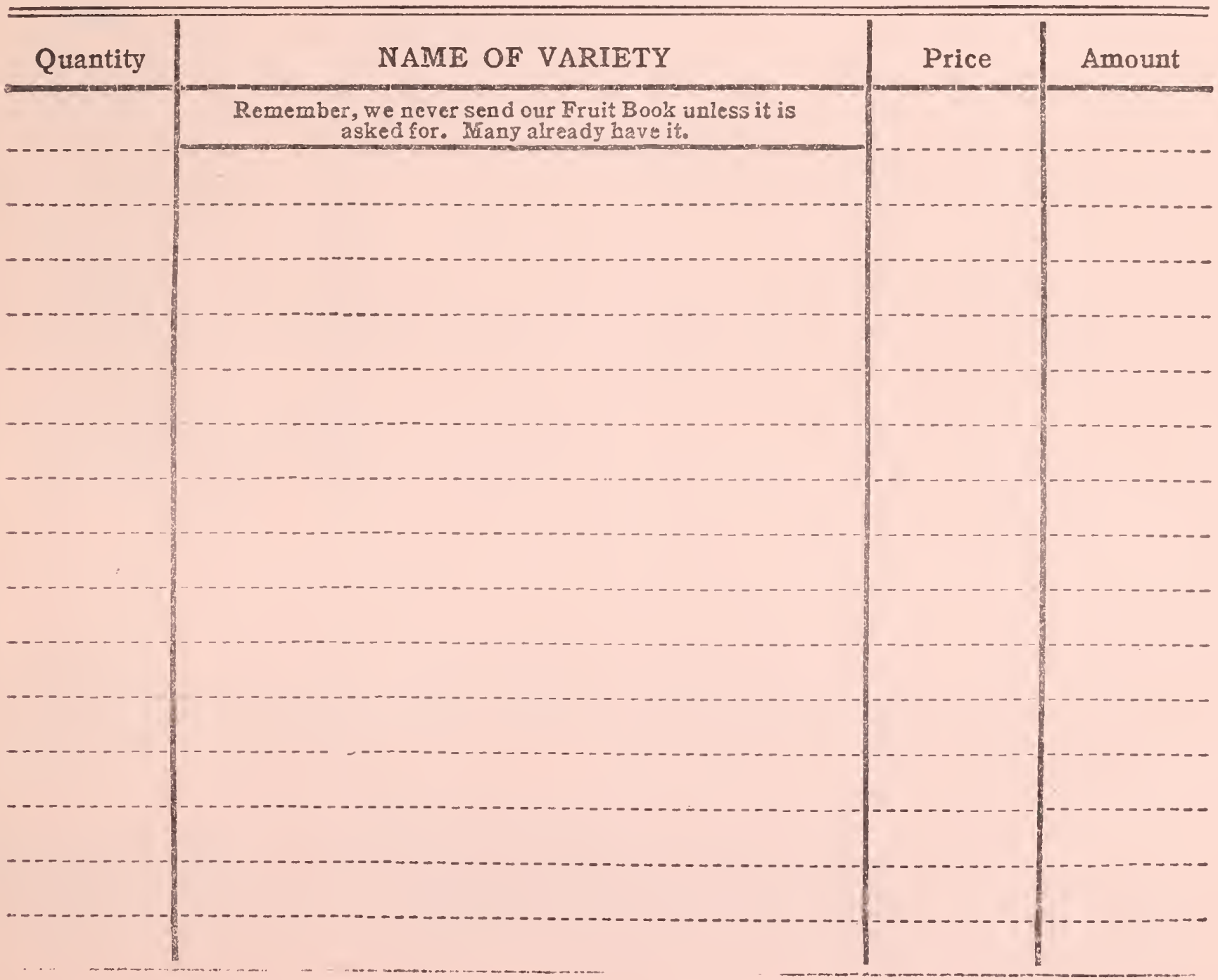




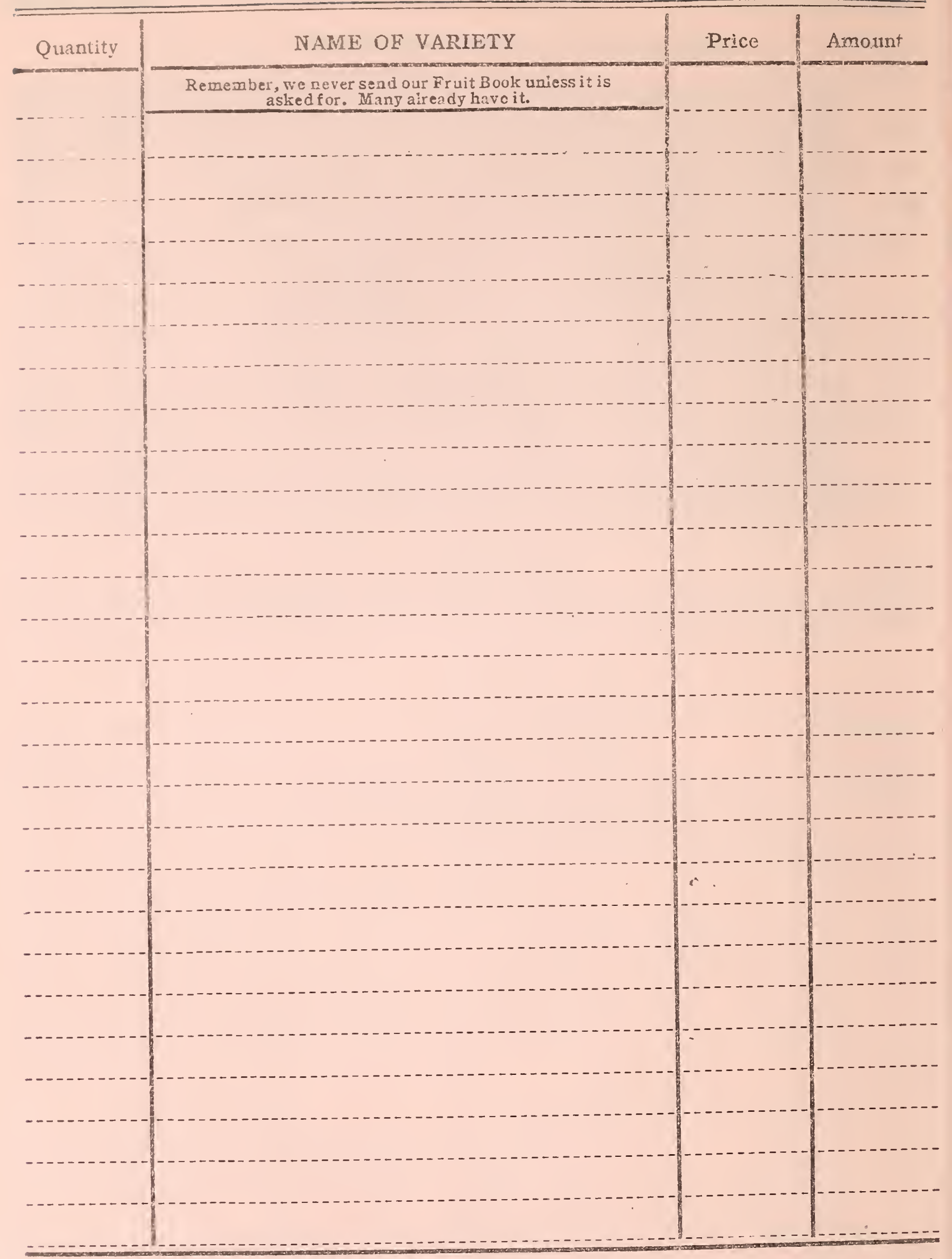

We deliver free only when especially so stated. See collections on pages $3,5,6,14$, $16,21,45$ and 46 .

But no pains are spared to pack light, and secure the lowest possible express or freight rates.

PARCET, POST-When cheaper and better for our customers, we ship small orders by parcel posc C. O. D. for parcel post charges. We ship C. O. D., as it saves extra trouble and the C. O. D. charges are less than postage would be on bili, were we to send it. If you prefer express, so state on order. 


\section{Flowering and Other Shrubs-Continued}

\section{JAPAN QUINCE}

Produces bright scarlet flowers, in great profusion, in early spring; very attractive and hardy. One of the best hardy slirubs. Price 75 cents each.

\section{JASMINUM}

Humile. Nearly an evergreen; bright yellow flowers; almost a continual bloomer. 60 cents each.

Naked-Flowered Jasmine. A graceful slirub, with quadrangular, drooping branches. Hoilage dark green, falling in late autumn. Flowers bright yellow, opening in early spring, or on warm days in winter. 3 feet. Fobruary to March. $75 \mathrm{c}$ each.

\section{KERRIA JAPONICA}

(Japanese Rose). Bright yellow flowers, giving striking eftects in spring. Slender green branches 4 to 6 feet long, with rough. reined leaves, Foliage attractive throughout the summer. Price 75 cents each.

\section{LILAC}

Common Lilac. The well-known old-fash ioned Lilac. Hardy and vigorous; endures neglect and blooms abuldantly. 75 cents each.

Common White. Flowers produced in slender panicles; pure white and fraglant. 75 cents each.

Persian Lilac. Flowers white. A graceful shrubby plant with narrow leaves. Price 75 cents each.

Rothomangensis. A distinct hybrid variety, with reddish flowers; panicles of great size and very abundant. One of the finest. 75 cents each.

Villosa. A species from Japan. Large branching panicles: flowers light purple in bud, white when open; fragrant. E'specially valuable, as its flowers appear two weeks after those of other Lilacs. i5 cts each.

Peach, Double Flowering. A dwarf-grow ing tree which is completely covered with beautifully formed and highly-colored fiowers in spring. Makes a handsome show, either in misses or single specimens. White and red. 75 cents each.

\section{PEARL BUSH}

In April and May the busll is literally covered with white star-shaped flowers, borne in racemes. The leaves are bright green and fade to brilliant tones of yellow in the fall. One of the most beautiful early flower. ing shrubs. Price 75 cents eacli.

\section{POMEGRANATE}

Very valuable, summer-flowering, tall-grow. ing shrubs. Perfectly hardy in the South. klowers are pruduced in great profusion very early in May, and last almost during the entire sunmer. Price $\$ 1.00$ each.

\section{PHILADELPHUS}

Old-fashioned shrubs, much admired for their fragrant, white, star-like flowers, which are borne in a great profusion during May. Will succeed in partial shade.

Philadelphus Coronarius. Common Mock Orange. A hardy shrub attaining a height of 8 to 10 feet, with upright, often arching branches. Bright green leaves 2 to 4 inches long. Deliciously fragrant, creamy white flowers borne in great profusion. Price 60 cents each.

Grandiflora. Large-flowered Mock Orange. Rather tall, with graceful, spreading branches. Leaves bright green, 2 to 4 inches in length. Its Howers are the glory of this famous shrub; they are large, pure white and are borne in pairs of threes. Price $60 \mathrm{c}$ each.

\section{PRUNUS PISSARDII}

Purple-leaved Plum. One of the most desirable of the purple-leaved trees, as it re tains its color throughout the season and holds foliage very late. A fine specimen for bringing color into the shrubbery border. $\$ 1.00$ each

\section{RED-BUD}

Judas Tree. A small shrubby tree, shapely and uniform, bearing masses of reddish purple flowers, resembling small sweet peas before the leaves appear. 15 to 20 feet. April 5 to 25. \$1 each.

\section{SCOTCH BROOM}

One of the finest yellow tlowering shrubs, bearing in spring a profusion of yellow pea. shaped flowers along the entire length of the branches. Price 75 cents each.

\section{SNOWBERRY}

(Racemosus). Inconspicuous rose-colored flowers in June and July; leaves thin, dark green; fruits large. 60 cents each.

\section{SNOWBALL}

Old-Fashioned Snowball. Hardy, succeeds with little care. Hlowers, white in cluster. 75 cents each.

Japanese Snowball. Surpasses any variety in Howers and foliage, if planted in partially shaded places. $\$ 1.00$ each.

\section{PLEASED WITH SERVICE AND STOCK}

The shrubs have been received. They reached me in perfect condition, and are the nicest I ever saw, just as everything else I've seen from your company. It's a pleasure to deal with you. Wishing you continued success. 


\section{Flowering and Other Shrubs-Continued}

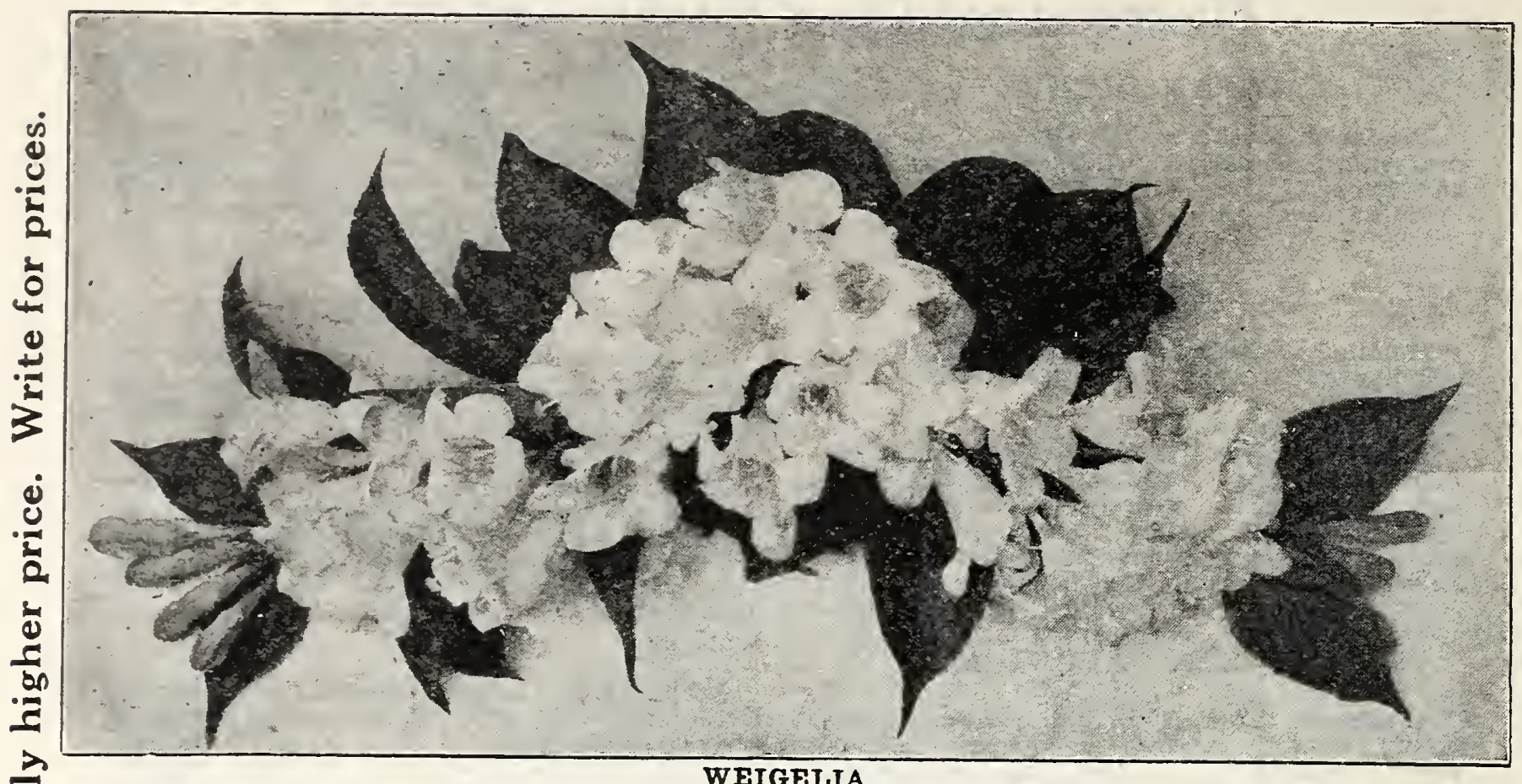

\section{SPIREAS}

An indispensable group of flowering shrubs showing great diversity in size, character and time of bloom. They are exceedingly showy and do best in fairly rich soil.

Anthong Waterer. Free flowering. Crimson blooms in rather dense corymbs. A compact shrub. 3 to $4 \mathrm{ft}$. Bloom from June to frost, if kept growing and the old head clipped off. 75 cents each.

Billiards Red. Bright rose-colored flowers; bloom nearly all summer; desirable. $75 \mathrm{c}$ each.

Billiards White. Very similar to the rosecolored, but blossoms pure white. 75 cents each.

Blue Spirea or Common Bluebeard. A dwarf growing shrub, producing free, lavender blue flowers from mid-summer until Autumn; very effective for massing. 75c each.

Bridal Wreath. A very beautiful variety; flowers pure white, small and very double; blooms very early. $75 \mathrm{c}$ each.

Bumalda. Cluster of beautiful rose-colored flowers in corymbs. 2 to 3 feet. July to September. Price $75 \mathrm{c}$ each.

Callosa Alba. White flowers in dense corymbs 2 to 3 feet. June to september. $75 \mathrm{c}$ each.

Douglas. Flowers deep pink, in dense panicles. Better foliage than that of $\mathrm{S}$. Billardii. Upright grower. 4 to 6 feet. June and July. $75 \mathrm{c}$ each.

Opulifolia Aurea. Distinguished by its golden yellow foliage and double white tlower. Blends well with any planting of shrubs. 75 c each.

Prunifolia. Bridal Wreath. The long, slender branches form great garlands of snowwhite double blooms, so closely are the flowers set along the entire length of stems. $75 \mathrm{c}$ each.

Thunbergii. Low growing, rounded form Delicate foliage, which takes and retains most lovely tints in autumn. Small white flowers in profusion in March. A fine plant. 75c each.

Van Houttei. The finest and most satis. factory of all spireas either singly or among other shrubs. It forms a round and graceful bush, with arching branches, which, in April and May, are set from end to end with beautiful white blossoms. A shrub which cannot be overlooked. $75 \mathrm{c}$ each.

\section{SUMAC}

Smooth. A large shrub or small tree. Leaves compound, turning scarlet in autumn Crimson fruit-clusters remain all winter. Price $75 \mathrm{c}$ each.

\section{TAMARIX}

Africana (African Tamarisk). A tall, grace. ful shrub, with small foliage like the Juniper, and delicate small, rosy purple flowers, pro. duced in spikes; very pretty. Price $60 \mathrm{c}$ each.

Tetranda. The most beautiful of the genus; flowers pale pink; blooms late summer. Price $60 \mathrm{c}$ each.

\section{TEA'S WEEPING MULBERRY}

The Weeping Mulberry is a very ornamental tree for lawn plantings. 'The limbs are pendulous, and fall to the ground, presenting a pleasing fountain effect. 2 year trees, $\$ 3.50$ each.

\section{VITEX AGNUS-CASTUS}

Chaste Tree. A showy shrub or small tree, with wide spreading branches. Lavender-blue flowers borne in dense terminal racemes in June and July. Exhales an agreeable aromatic odor when bruised. 2 to $3 \mathrm{ft} ., 60 \mathrm{c}$ each.
OUR GUARANTEE the broad guarantee given on page 35 . It is, we believe, the broadest guarantee given by any nursery in the country. 


\section{Flowering and Other Shrubs-Continued}

\section{WEIGELIA}

Hardy, easily grown and great bloomers. Of erect growth while young, but gradually spreading and drooping as they acquire age. They produce, in June and July, superb, large trumpet-shaped thowers of all shades and col. ors from pure white to red.

Candida. A strong-growing new variety bearing pure white flowers in great profusicn. One of the best. Price 60c each.

Eva Rathke. Smallest growing of the Weigelas. Flowers deep glowing red and very beautiful. Price $75 \mathrm{c}$ each.

Rosea. An elegant shrub, with fine rose colored flowers. Quite hardy; of erect, com. pact growth. Blossoms in June. Price $60 \mathrm{c}$ each.

\section{CLIMBING VINES}

Clematis (Paniculata). Valuatle for en, ering arburs, trellises and porches. small, white flowers. borne in long. slender ilus ters, cover the plant witb a mans of lolmom August. Price $50 \mathrm{c}$ each.

English Ivy, A grand, high-(0limbing ever green vine. clinging 10 wall. or truiks trees and often attaining great helght. 1)arh green leaves of exquisite outline and beint? Price 50c each.

Virginia Creeper. The large, Mandsum, leaves are deeple cut into five lobes. Ithe blue berries contrast handsomely whth the brilliant crimson shades which the fillity. assumes when touched by frost. Prion sil. each.

Wisteria (Japanese). A tine clumber, has ing purple thowers. lorile in long. "1p+11 ters. Price $50 \mathrm{c}$ each.

\section{SHRUB COLLECTION FOR $\$ 5.00$}

12 Two-Year Shrubs Delivered Free With Plant Food Greatly Hastening Growth. Every Plant Insured

1 Coral Berry $60 \mathrm{c}$

1 Deutzia Rosea $60 \mathrm{c}$

1 Butterfly Bush $.75 \mathrm{c}$

1 Weigelia Rosea $60 \mathrm{c}$

1 Spirea Thunbergii $75 \mathrm{c}$

1 Spirea Anthony Waterer .. $.75 \mathrm{c}$
1 Spirea Callosa Alba $.75 c$

1 Forsythia Verdissima .............50c

1 Althea Peonifolium ….................50 c

1 Philadelphus Coronarius ..........60c

1 Althea Ardens $50 \mathrm{c}$

1 Deutzia Pride of Rochester 60c

\section{ALI 12 SHRUBS DELIVERED FREE WITH PLANT FOOD (Cash with} Order)

\section{OUR GUARANTEE}

Our stock must satisfy our customers. We strive as hard as mortals can to fill every order just right, but if by any means a mistake should occur, we want to know it. Write us if anything whatever is wrong. An orrler is nor consileperl complete on our books until our customer is satisfied. In other words, we guarantee satisfaction, and our bank references will tell you we are gond for our contract.

We want our customers to feel that we are just as much interested in their success with our trees and plants as they are themselves and are.just as anxious for them to succeed with them. Should they at any time need information as to cultivation, spraying, etc., our forty years' experience is at their command.

\section{OUR REFERENCES}

Write and find out all about us (enclosing stamped envelope for reply) from (inzells Bank, Henderson, N. C.; First National Bank, Henderson, N. C.; Citizeus' Natınal Bunk Raleigh, N. C.; Union Bank and Federal Trust Company, Richmond, la.

\section{DELIGHTED WITH PLANTS}

I wish you could see the Amoor River Privet Hedge which we set out in May with fear and trembling, as it was so late in the season. I know you would be proud of having firnished the plants. 


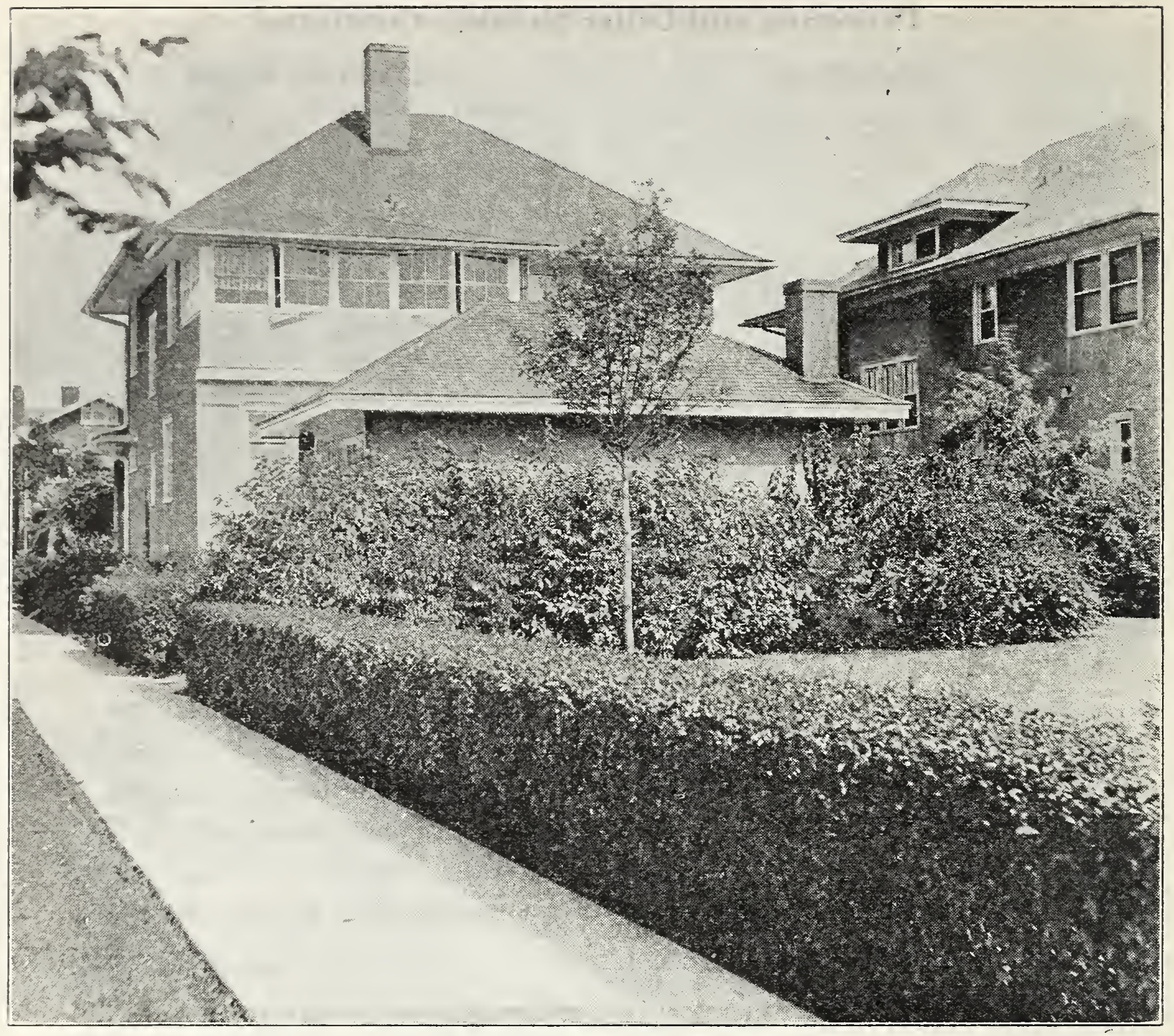

Amoor River Privet makes a neat boundary a

\section{Grow a Perfect Hedge as Quick as a Hill of Beans}

Our Book, telling and showing by plain cuts just how to grow a perfect hedge, is free with every order of $\$ 5$ and over.

Amoor River Privet. A quick and close-growing plant. Color a beautiful light green. Remains green through the hottest summer and coldest winter. Makes a magnificent hedge.

California Privet. We can also supply this variety, but recommend Amoor River, as it is a genuine evergreen.

Berberi Thunbergii (Japanese Barberry). The best deciduous Hedge Plant. It is beautiful throughout the year. Its abundant crop of bright red berries makes it as attractive in the fall as in the summer. It requires no attention, except occasional cutting back of a few straggling branches. Hardy, of easy culture, and will grow in any soil or situation. Price, 50 cents each. $\$ 25.00$ per 100 . Select three-year plants.

Ibota Privet. One of the best shrubs for hedges, and likewise excellent for specimen use or mass plantings. Small white flowers are borne in numerous clusters and followed by black berries. The leaves are dark green and possess a brilliant luster. Price, 50c each.

Lodense Privet. This pretty new, dwarf variety grows very compact and symmetrical with little trimming. Particularly fine for low hedges and borders. $12-15$ inches 25c each; $\$ 2.50$ per dozen. 


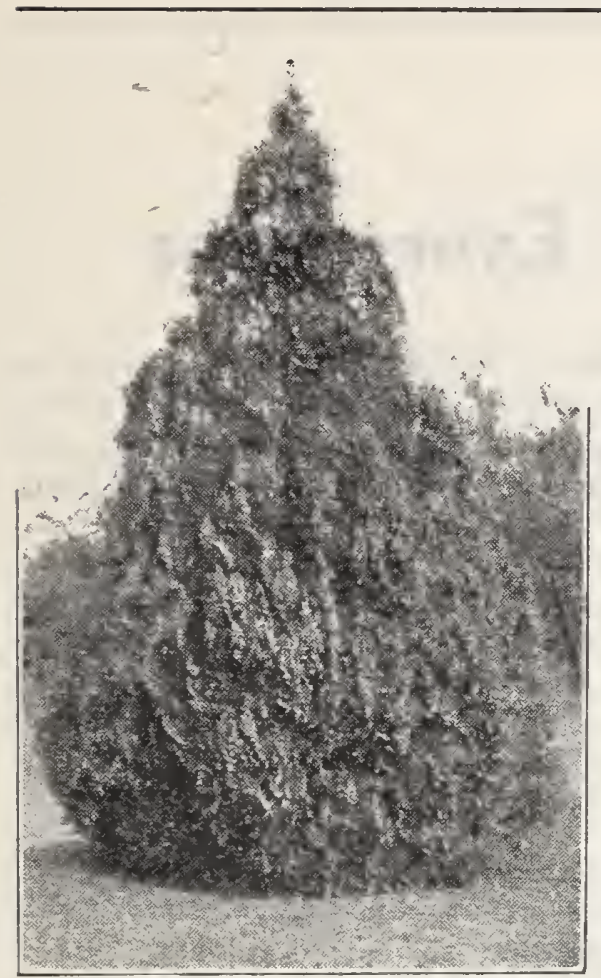

AMERICAN ARBORVITAE
One of the best for the South

\section{Evergreens}

In many parts of the South too much attention is paid to crops and entirely too little to the appearance of the house and grounds.

You can easily avoid bare grounds by the careful arrangement of evergreens. No matter how severe the winter may be, they are always green and cheerful, and in shape are always beautifully symmetrical.

\section{ARBORVITAE}

American Arborvitae. Valuable as a single specimen and for hedges. Can be trimmed to any form. One of the best for soutliern home grounds. $2-2 \frac{1}{2} \mathrm{ft}$, price $\$ 2.50$ each.

American Compacta Arbor Vitae. A dwarf arborritae of compact hiabit. Color, a bright green. 18.24 inch, $\$ 2.50$ each.

Bicta Aurea Nana. One of the best dwarf golden evergreens. It is compact, symmetrical, and very conspicuous in winter. $12-15$ inch, $\$ 2.50$ each; 15-8 inch, $\$ 3.00$ each.

Biota Compacta. A compact, bushy pyramidal form with dense bright green foliage. 18.24 inch, $\$ 2.50$ each.

Chinese Arborvitae. A medium-sized dense-growing erergreen whose foliage turns to rich brown in autumn. Of rapid growth. $2.3 \mathrm{ft}$, price $\$ 2.50$ each; $3.4 \mathrm{ft} ., \$ 3.50$ each.

Chinese Pyramidal Arbor Vitae. A compact, spire-like form succeeding admirably in this locality. It retains its bright green color throughout the winter, and succeeding in almost any soil or situation. Attains a height of 12 to 15 feet. $2 \frac{1}{2}$ to $3 \mathrm{ft}$., $\$ 2.50$ each.

Globe Arborvitae. Almost a perfect globe in its ontline, attracting considerable attention because of the form. Especially valuable for specimens and formal plantings. The foliage is rery compact. 18.24 inch, price $\$ 3.00$ each.

Hovey Arborvitae. Similar to the preceding, but more open in growth and somewhat larger. Specially useful in plantings where the space is limited. A strong and rigorous sort. 15.18 inch, price $\$ 2.50$ each.

Lobbi Arbor Vitae. A splendid rariety, resembling the American Arbor Vitae in shape, but foliage is dark green and holds color well througliout the year. $2-2 \frac{1}{2} \mathrm{ft} ., \$ 3.50$ each.

Pyramidal Arbor Vitae. This is strikingly attractive, being perfectly pyramidal in shape, spreading very little at its base and retaining the shape without shearing. The color is deep rich green, and like all Arborritae is easy to transplant. 18-24 inch, $\$ 3.00$ each.

Tom Thumb Arborvitae (Ellwangerana). Low, broad, prramidal, with slender branches clothed with two kinds of foliage. Tery symmetrical and popular for beds, borders and foundation planting around base of house or porch. $15-18$ inch, price $\$ 2.50$ each.

The trees recently ordered from you have arrived $O$. K. and been planted; stock appeared unusually healthy and good, and wish to thank you again for such nice service.

J. B. Mixson, Florence, S. C. Feb. 16, 1931.

Have been receiving prices from different companies but $I$ an afraid to buy from some of these. I bought strawberry plants, peach and pecan trees from you some years ago and they are wonderfully thrifty, also productive.

Mrs. H. E. Goan, Greenville, Tenn. Feb., 1931.

The grapevines you sent me are the nicest I ever saw come from a nursery, and I am sure they will do fine.

G. T. Sykes, Leaksville, N. C. Feb. 16, 1931

The strawberry plants you recently shipped were the finest I ever saw. C. B. Willingham, Rome, Ga. March 7, 1931. 


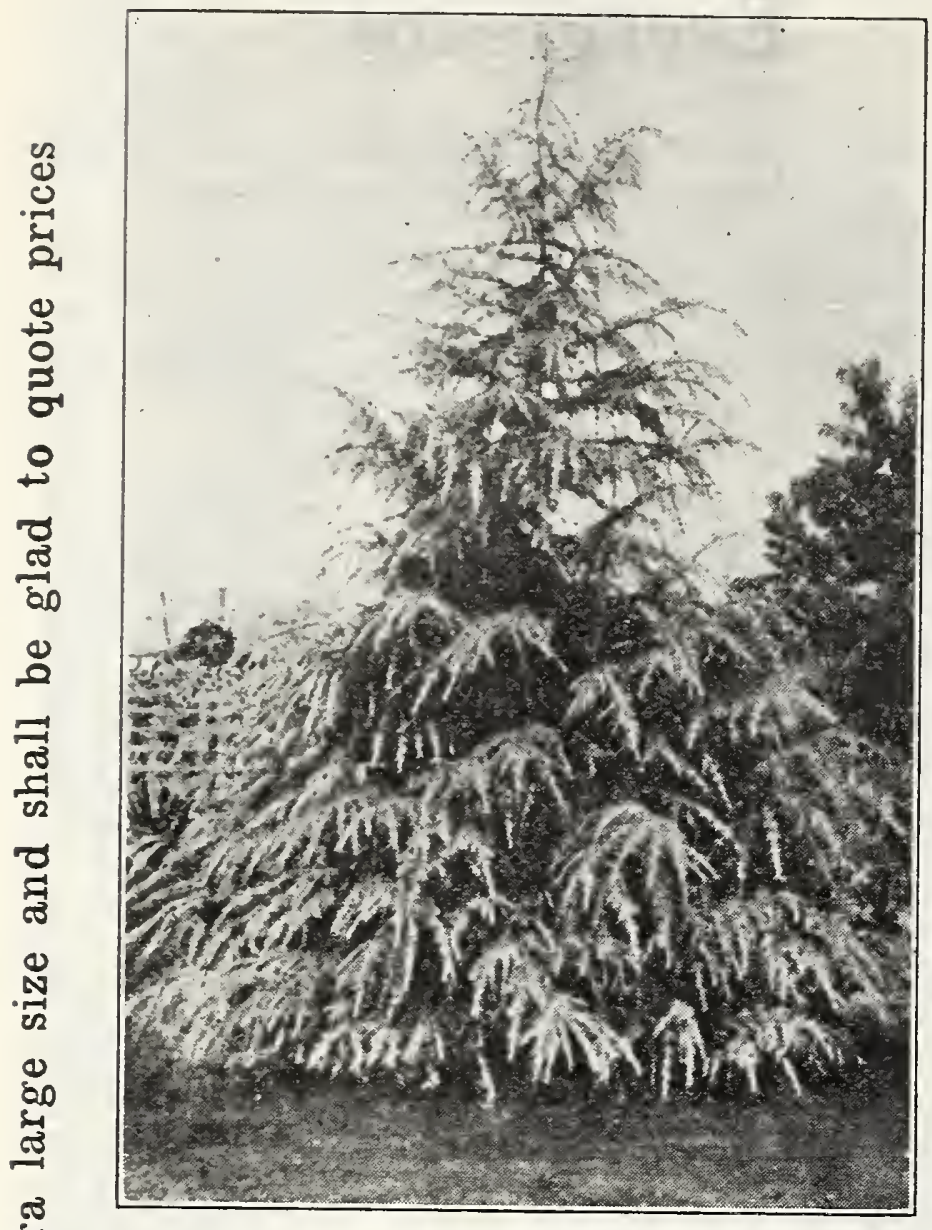

Cedrus Deodara

\section{Evergreens}

Cedrus Deodara. The great Cedar of the Himalayan Mountains. Stately, glaueous green foliage, feathery branches, spreading. A striking beauty on the lawn. $2-3 \mathrm{ft}$., $\$ 4.00$ each.

Cedar of Lebanon. The Cedar of Lebanon, spoken of in the Bible. An upright fairly fast growing tree with straight center leader and broad tapering branches, forming a beautiful pyramidal tree. 2-3 ft., $\$ 4.00$ each.

Virginia Glauca (Blue Virginia Cedar). Beautiful silvery-blue foliage. Grows tall and somewhat slender, developing into a pleasing specimen. Very popular. 2.3 ft., $\$ 5.00$ each.

Juniper, Ashford. This type of Juniper with short needles of a silvery greyish green, does not die out or turn brown in the center and is of a more graceful form than the plain Juniper or Irish Juniper. $2-3 \mathrm{ft} ., \$ 3.00$ each.

Juniper, English. A magnificent variety; highly valuable for specimen planting. Silvery blue foliage. Tall growing. 2-3 ft., price $\$ 3.00$ each.

Juniper, Excelsa Stricta. Dwarf compact. A very ornamental tree decidedly conical in form, well branched and densely clotked with grayish-green, glaucus foliage. $12-18$ inch, $\$ 2.50$ each.

2 Juniper, Irish. Probably the most beautiful of the species; very graceful. Foliage has silvery blue tinge. $2-2 \frac{1}{2} \mathrm{ft}$., price $\$ 3.00$ each.

\&

Juniper, Prostrate (Communis Depressa). Broad spreading, dwarf, growing to height of three feet; foliage dark green. $2-3 \mathrm{ft}$. spread, $\$ 4.00$ each.

Juniper, Pfitzeriana. The best of all Junipers. Spreading, graceful; branches horizontal, often forming a flat spreading cap. Especially good to use for foundation plantings and rockeries. Very hardy. 18.24 inch, $\$ 2.50$ each.

Juniper, Savin. A dark, rich green Juniper of low, spreading habit. Splendid for where a dwarf plant is wanted in beds or groups or in rock gardens. 15-18 in., $\$ 2.50$ each.

Juniper, Swedish. Compact and upright in growth, resembling the Irish Juniper but more bushy and not quite so slender. $2 \frac{1 / 2-3}{\mathrm{ft} .}, \$ 3.00 \mathrm{each}$.

( Juniper, Waukegan. Steel-blue foliage, turning purple in autumn. Dwarf, trailing. 18 - 24 inch, $\$ 2.50$ each.

Norway Spruce. Grows into tine large trees, or if it is kept clipped it will make a good hedge. $2-3 \mathrm{ft}$., price $\$ 2.50$ each.

Cypress, Lawson. Bright green foliage, leaves closely oppressed. Branches somewhat pendulous and spreading. One of the most beautiful evergreens when developed. $2-3$ ft. $\$ 3.50$.

Cypress, Lawson Blue. A compact pyramidal form, with bluish-green foliage. One of the best. $1 \frac{1 / 2}{2}$ to $2 \mathrm{ft} ., \$ 4.00$ each. 


\section{Evergreens}

\section{RETINOSPORA (Chamaecyparis)}

Retinospora Lutea. A very dwarf form with golden yellow plume-like foliage; compact and globular in habit. Excellent for tubs. 15-18 inches, \$2.50 each.

Retinospora Obtusa. One of the oldest trees of Japan. Has norizontal, fern-likt branches, slightly drooping. 3-4 ft., \$3.50 each.

Retinospora Pisifera. Foliage bright green, somewhat pendulous. This is a very valu able and hardy form, and is not commonly grown, $2 \cdot 3 \mathrm{ft} ., \$ 3.00$ each.

Retinispora Plumosa. Small, dense, plume-like foliage of a light green color. suitable for massed planting. $2.2 \frac{1}{2} \mathrm{ft}$., price $\$ 3.00$ each.

Retinispora Plumosa Aurea. Same as preceding except the foliage, which is golden. $2-21 / 2 \mathrm{ft}$., price $\$ 3.50$ each.

Retinispora Squarrosa Veitchif. Dense growth; soft, beautiful, silvery blue foliage, arranged in spirals which gives the impression of boiling over. $2.3 \mathrm{ft}$., price $\$ 3.50$ each.

Retinospora Sulphurea. Similar to above variety in form. Foliage sulphur yellow. $2-3$ ft., $\$ 4.00$ each.

\section{Broad-leaved Evergreens}

This classification includes a number of highly desirable ornamental plants which we have learned by practical experience to be splendidly adapted to Southern planting. All are desirable beeause of their foliage, which remains bright and green the year round; many ot them have lovely flowers and bright berries.

Most of the broad-leaved evergreens are easily grown. Given a fairly rich. moist, well drained soil, and sufficient mulching to keep the roots from extremes of heat and cold. most of these will grow and thrive with comparatively little care, providing those charming effects of foliage and flower that every garden needs, and that are the admiration of all. Almost all do well in partial shade. In transplanting, the leaves should all be trimmed off, to insure success. Cut back stray shoots in.early spring; otherwise they require little pruning.

Abelia Grandiflora. A very free-flowering shrub. In the sruth, the dark, glossy leaves remain on the branches all winter. 'I'he white flowers, touched with pink, are borne in great profusion, and appear from early summer until frost. They are about an inch long and have a deep, slender throat. 18 to 24 in., $\$ 1.00$ each. 2 to $3 \mathrm{ft} ., \$ 1.25$ each.

Azalea Amoena. A dwarf plant, producing small, claret-colored blogms in April. 8-10 inch, $\$ 2.00$ each.

Azalea, Hinodegiri. Similar to above, but a more vigorous grower. Carmine flowers in early spring. 8.10 inches, $\$ 2.50$ each.

Dwarf Box. Succeeds in most well-drained soils, requiring protection, however, against extremes of both heat and cold. Some shade is nearly always desirable. Leaves small, glossy, bright green. $8-10$ in., $\$ 1.00$ each.

Tree Box. Succeeds in most well-drained soils. Sume shade is nearly always desir. able. $15-18$ inch, $\$ 2.50$ each.
Cherry Laurel. A hardy evergreen with shing green leaves. A tine tree for grouping or to be used as a background. Can also b. trimmed into formal shapes. 12 to 15 in. $\$ 2.00$ each; 18 to 24 in., $\$ 2.50$ each.

English Laurel. A valuable shrub. whos. principal merit is its great vigor, beautiful brcad shining foliage, and ease of cultivation 18 to $24 \mathrm{in.} \$ 2.50$ each.

Eleagnus, Pungens. Leaves long dark green above, silvery beneath. Creamy white, fra grant flowers. $\mathbf{1 8 . 2 4}$ inches, $\$ 2.00$ each.

Euonymus Japonica. Evergreen Eurmymus. Handsome, laroe shrubs, glossy green leares. hold their color all winter; hardy. Red berries. Extra select plants. 2 to $3 \mathrm{ft}$. $\$ 1.50$ each.

Euonymus Sieboldiana. New. A very at tractive creeping Japanese variety, with hand. some dark green foliage. Perfectly liardy in any climate. 12 to 18 in., $\$ 1.00$ each. 


\section{Broad-leaved Evergreens}

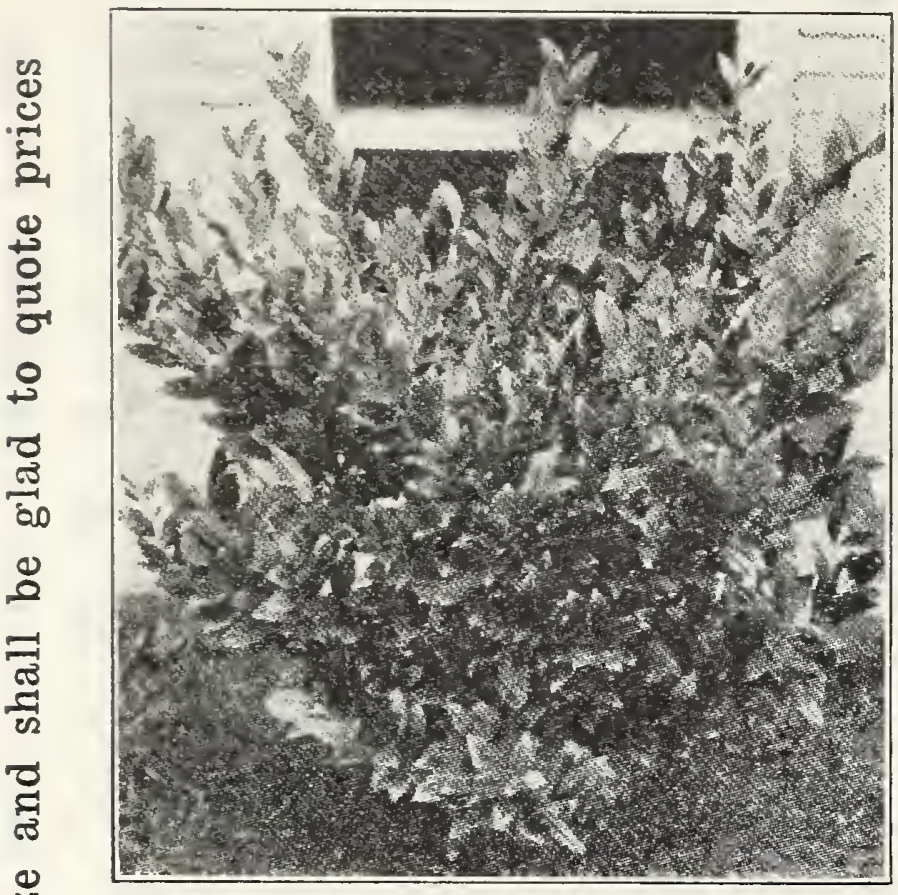

Ligustrum Lucidum

Gardenia (Cape Jasmine). Popular for planting in the South, but not hardy outof-doors north of Nashville, Tennessee. Bright, thick, glossy leaves with large waxy-white flowers of great fragrance. Blooms from May until frost. 18 to 24 inch, $\$ 1.50$ each.

Iiex Crenata (Japanese Holly). A shrub with small, glossy, dark green leaves and black berries. At a distance resembles boxwood. Hardy in the South and makes a good hedge plant. 18-24 in., $\$ 3$ each.

Japanese Spurge. A low-growing evergreen plant which spreads by rootlets underground. In spring the now bright green leaves form a decided contrast to the darker foliage of the previous season. 25 cents each.

Ligustrum Japonicum. A beautiful, broad-leaved evergreen shrub of dense and symmetrical outline. The creamy white flowers are borne in panicles and followed by purple berries. G'rows 10 to 15 feet tall. Extra fine plants. 2 to $3 \mathrm{ft}$., $\$ 1.50$ each; 3 to $4 \mathrm{ft} ., \$ 2.00$ each.

Ligustrum Lucidum. Large, thick, dark shiny green leaves. Flowers white, produced in May and followed by black berries, which are retained through the winter. Attains a height of 10 to 12 feet. A very desirable variety. Extra tine plants. 18 to 24 in., $\$ 2.00$ each. 2 to $21 / 2 \mathrm{ft}$., $\$ 3.00$ each.

Ligustrum Nepalense. Similar to Ligustrum Lucidum, but smaller in growth and leaf and more compact. 18-24 inches, $\$ 2.00$ each, $\$ 18.00$ for 10.

Ligustrum Quihoui. Late-flowering privet. An attractive shrub of spreading habit. Native of China. Berries blue-black with a bloom. The showiest and latest flowering species. 3-4 ft., $\$ 1.50$ each; $\$ 15.00$ per dozen.

Lonicera Nitida. A splendid evergreen bush Honeysuckle, originally obtained from western China. The glossy leaves turn to an attractive shade of purple in the fall. 12 to $15 \mathrm{inch}, \$ 1.50$ each. है

Magnolia Grandiflora. Common evergreen Magnolia of the South, with large, handsome white blooms which, combined with its large, glossy green leaves, remaining on throughout the whole year, make this the greatest of all the southern ornamental trees. 2-3 ft., $\$ 2$ each.

Mahonia Aquifolium (Oregon Hollygrape). A small shrub having lustrous, dark green leaves, yellow flowers followed by dark blue berries. A splendid plant. 2.3 ft., $\$ 3.00$ each.

Mountain Laurel (Kalmia Latifolia). An evergreen shrub covered with rich foliage, glossy green above and yellowish green on the under side. Beautiful pink and white flowers borne in profusion the latter part of June. 18 to 24 in., $\$ 2.50$ each.

D Nandina Domestica. A brilliant orange-red shrub in winter, delicate foliage, dense, stocky. D. A dwarf Japanese plant. Leaves red when young and through the winter, dark green through 2. summer, clustered with red berries in autumn. $12-18$ inch, $\$ 1.50$ each; $2-3$ ft., $\$ 3.50$ each. \& Photinia Serrulata. A large evergreen shrub or small tree, the foliage of which becomes very conspicuous in fall, when it assumes a red shade. Hlowers white, in large ᄃु corymbs, produced in early spring. 2 to $3 \mathrm{ft}$., $\$ 2.50$ each.

Pyracantha Lalandi. "Burning Bush." An evergreen shrub of spreading habit; foliage rich dark glossy green; clusters of white flowers in the spring are followed by a wealth of orange-colored berries which remain on the plant all winter. 3-4 ft., $\$ 3.00$ each.

Rhododendron Catawbiense. Flowers lilac-purple. Large clumps. $\$ 3.50$ each.

Rhododendron Maximum (Great Laurel). Pure white flowers. Large clumps. \$3.50 each.

Tea Plant (Thea Bohea). The Tea Plant of commerce. A broad compact, cone-shaped shrub with dark green foliage, producing white flowers with yellow anthers during fall and early winter. 18-24 inch, $\$ 2.50$ each.

The above Evergreens are shipped with a ball of earth attached to the roots-the only 6afe way to ship evergreens. All first-class specimens. 


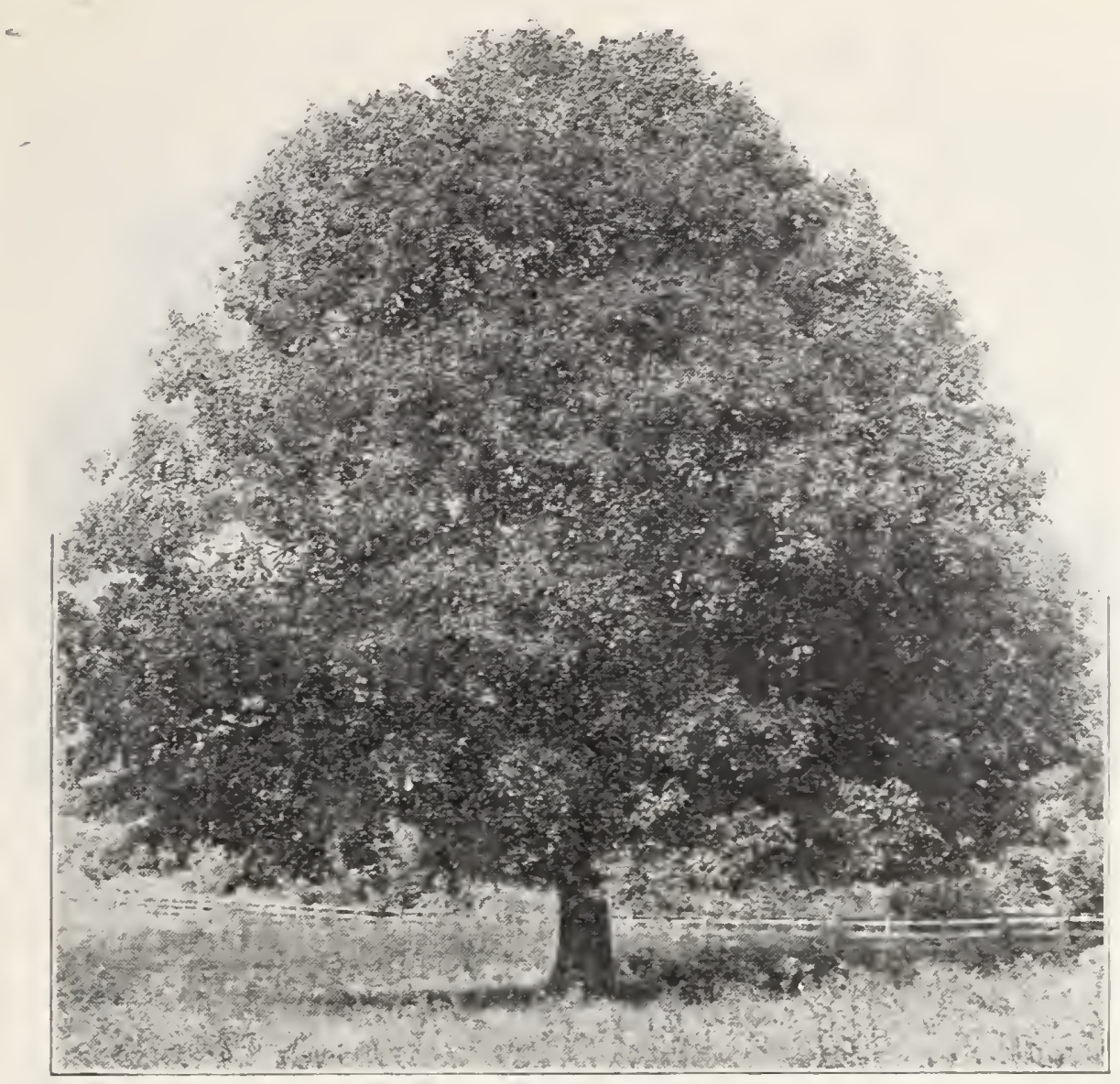

SUGAR MAPLE

The Best Maple for Quick, Permanent Shado.

\section{Shade and Ornamental Trees}

(Price List Page 44)

Aside from the satisfaction and comfort you will derive from properly planted and properly shaded grounds, do you realize that as an investment there is nothing that returns such dividends as the beautifying of the grounds around your home? Real estate men all over the country all agree that a place properly planted with trees and shrubs will, other things being equal, always find the quickest sale. The prices we name are for first-class, well-shaped, strongly-rooted trees.

Norway Maple. Very popular on account of its clean, large leaf of deep, rich green; stout, vigorous growth. A beautiful tree and makes a dense shade. Very hardy, easily transplanted, very compact in form, grows rapidly, and is exceptionally free from injurlous insects. 10 to $12 \mathrm{ft}$., $\$ 3.50$ each. $12 \mathrm{ft}$. and up, $\$ 4.00$ each.

Sugar Maple. Its fine, clean, prramidal growth and foliage make it very desirable. Une of the finest shade trees. A very popular American tree. Used extensively to good advantage for street and avenue planting. 10 to $12 \mathrm{ft} . \$ 3.00$ each. $12 \mathrm{ft}$. and up, $\$ 4.00 \mathrm{each}$.

Silver Maple. The most rapid growing of the Maples, a habit which combined with size, form, grace and beauty, gives it great value. The foliage is light green, silvery white on the under side. It is a very graceful tree, perfectly hardy, and is valuable for street planting where quick results are desired. 12 feet and up. \$1.50 each.

Schwedler Maple. Of the same habit as the Norway Maple except that it has reddish purple foliage in early spring changing to deep bronze in 11 idsummer and Autumn; very ornamental. 8 to $10 \mathrm{ft} ., \$ 3.00$ each.

Lombardy Poplar. A tall, slender, rapid-growing tree; useful in producing attractive effects in many situations. 8 to $10 \mathrm{ft}$., $75 \mathrm{c}$ each; 10 to $12 \mathrm{ft.}, \$ 1.25$ each.

Carolina Poplar. A large sized tree of very rapid growth. 8 to 10 feet, $\$ 1.00$ each.

Simoni Poplar. A remarkable new variety of the small-leaf Chinese Poplar of very pyramidal habit; resembles the Lombardy, but makes a more pleasing impression; a very rapid grower. $8.10 \mathrm{ft} ., \$ 1.00 ; 10.12 \mathrm{ft} ., \$ 1.50$ each.

Weeping Willow. A very beautiful tree of weeping habit, obtaining a height of 30 to 40 feet, with slender olive-green branches and long green leaves. Very beautiful where given plenty of room. 8 to $10 \mathrm{ft} ., \$ 1.50$ each.

Elm, American. A tall, stately tree with graceful branches. A fast grower. 8 to 10 ft., \$2.00 each.

Willow Oak. A beautiful shade tree. 10 to $12 \mathrm{ft.,} \$ 4.00$ 


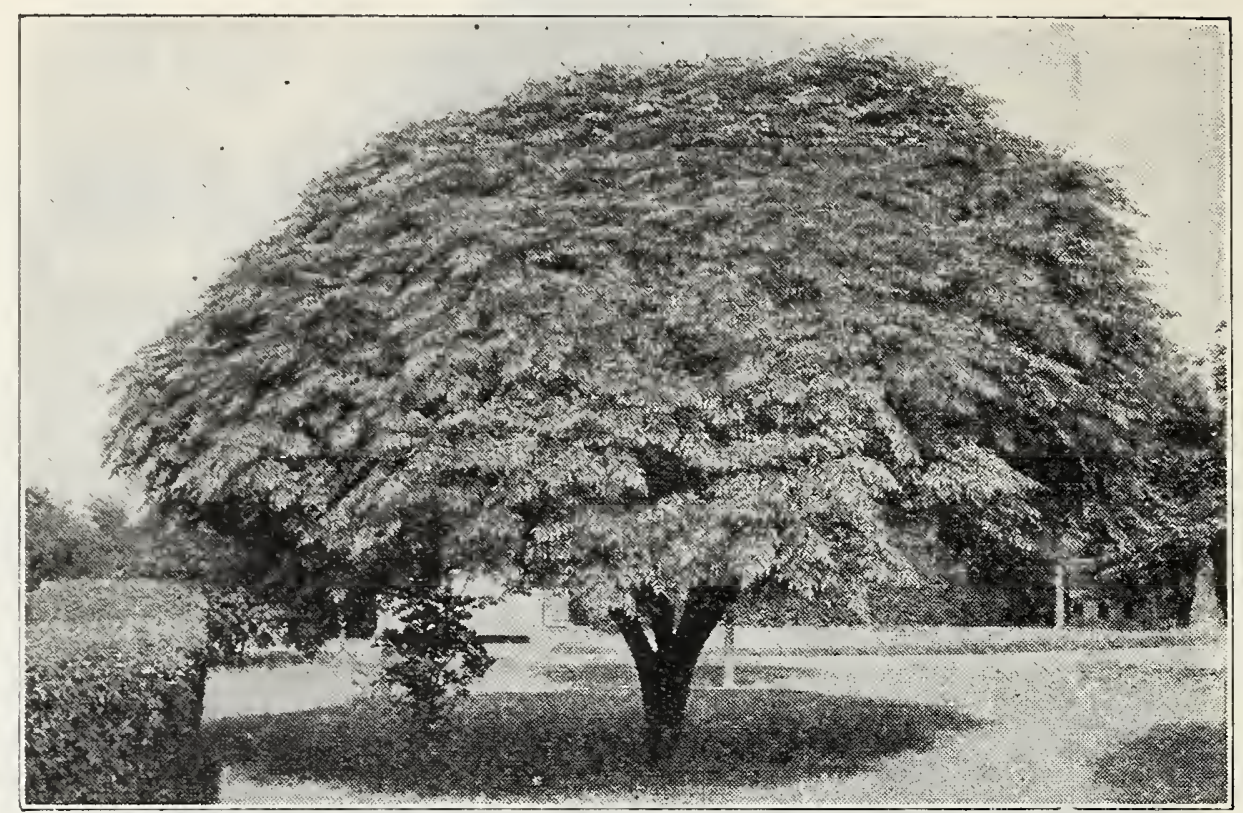

\title{
Shade and Ornamental Trees--Continued
}

\author{
(Price List on Pages 43 and 44)
}

Umbrella. For some years this has been most popular as a specimen tree for the lawn. It makes a fairly rapid growth, with a large spread, but flattish head. When it has grown for several years it bears quite a remarkable resemblance to an umbrella in shape.

A slight winter protection given by straw, paper or pine boughs tied about the trunk will promote more rapid growth for several years.

The tree has been so popular that some nurseries could not obtain the true strain, so they substituted other sorts. We absolutely guarantee that our trees are pure Umbrellas. First-class trees, $\$ 1.00$ each; extra tine, $\$ 1.50$.

Catalpa Bungii. A beautiful and valuable tree of rather dwarf growth. Forms an umbrella shape of deep green leaves striking in this effect. When used for borders of paths this tree gives a formal finish not readily obtained with other trees. We consider it one of the most beautiful trees of its kind. 5.6 ft., $\$ 2.00$ each.

Japanese Blood Leaf Maple. Leaves extremely bright red, also bark of the tree is red. Grows in shrub form, not for shade. Unquestionably as an ornament for the lawn it is without an equal. $1 \frac{1 / 2}{2}$ to $2 \mathrm{ft}$., $\$ 6.00$ each; 2 to $3 \mathrm{ft}$., $\$ 7.50$ each.

Pussy Willow. A small tree with upright or ascending branches. Leaves green, relatively large and broad. Catkins very numerous, appearing in early spring before the leares put nut. Handsrime in flower and greatly esteemed by reason of its earliness. 12 to $25 \mathrm{ft}$. February, March. $\$ 1.00$ each.

Cut-Leaved Weeping Birch. An extremely graceful variety with pendulous branches and finely dirided leaves. White bark. A splendid specimen plant. 8-10 ft., $\$ 2.50$ each.

European White Birch. A beautiful tree with white bark and with spreading and pendulous hranches when mature. Native of Europe. Leaves deep green in summer with tones of yellow in autumn. This graceful tree is a handsome lawn tree. The birches always form interesting contrasts to other trees and to evergreens. 8-10 ft., $\$ 2.50$ each.

Chinese Elm. Beautiful, fast growing and hardy. "Greased-Lightning', would be a better name for this remarkable tree. It is the fastest growing snade tree we know of. Thrives everywhere. It is one of the first trees to leaf out in the spring and the last to shed the leaves in the fall. 5.6 ft., $\$ 2.50$ each.

The trees and plants arrived in good order. They were much larger and healthier lonking than I expected. I wish to thank you for the extra ones included. W. D. Lide, Decatur, Ga. March 11, 1930.

In 1928 I bought a collection of fruit trees from you and I just want to tell you what a wonderful orchard I have. My trees started in May and we have worlds of peaches. Every one who sees it says they just can't believe it. 'The trees are so heavily loaded we have to prop them all up and the fruit is lovely. My two plum trees were full too, and were file. I only wish you could have a photograph of it. Mrs. C. B. Box, Midnight, Miss July $12,1930$. 


\section{Price List-Fall and Winter 1931-32}

\section{STRAWBERRY PLANTS}

Grown by modern methods-that is from parent plants not allowed to weaken them. selves by fruiting last spring, and which just before planting were treated by fungicides. This renders the plants they produce free from the rust and fungus which annually lessen the Strawberry crop of the country 10 to 50 per cent. See pages 8 and 9.

\begin{tabular}{|c|c|c|c|c|c|c|c|c|}
\hline & $\begin{array}{c}10.000 \\
\text { and } \\
\text { over, } \\
\text { per } \\
1,000 \\
\end{array}$ & $\begin{array}{r}5,000 \\
\text { to } \\
10,000 \\
\text { per } \\
1,000 \\
\end{array}$ & $\begin{array}{c}3,000 \\
\text { to } \\
5,000 \\
\text { per } \\
1,000\end{array}$ & $\begin{array}{c}1,000 \\
\text { to } \\
3,000 \\
\text { per } \\
1,000\end{array}$ & 500 & 100 & 50 & 25 \\
\hline $\begin{array}{l}\text { Excelsior (Per.) Standard } \\
\text { Extra Early Berry............. }\end{array}$ & $\$ 6.00$ & $\$ 6.00$ & $\$ 6.00$ & $\$ 6.00$ & $\$ 3.75$ & $\$ 1.50$ & $\$ 1.00$ & .75 \\
\hline Heflin's Early (Per.) ................. & 6.00 & 6.00 & 6.00 & 6.00 & 3.75 & 1.50 & 1.00 & .75 \\
\hline Premier (Per.) & 6.00 & 6.00 & 6.00 & 6.00 & 3.75 & 1.50 & 1.00 & .75 \\
\hline Lady Corneille (Per.) & 6.00 & 6.00 & 6.00 & 6.00 & 3.75 & 1.50 & 1.00 & .75 \\
\hline Chesapeake (Per.) & 6.00 & 6.00 & 6.00 & 6.00 & 3.75 & 1.50 & 1.00 & .75 \\
\hline Blakemore (Per.)......................... & 8.00 & 8.00 & 8.00 & 8.00 & 4.50 & 1.75 & 1.00 & .75 \\
\hline MISSIONARY (Per.) & 5.00 & 5.00 & 5.00 & 5.00 & 3.50 & 1.50 & 1.00 & .75 \\
\hline Imp. Lady Thompson (Per.) & 6.00 & 6.00 & 6.00 & 6.00 & 3.75 & 1.50 & 1.00 & .75 \\
\hline KLONDYKE (Per.) & 5.00 & 5.00 & 5.00 & 5.00 & 3.50 & 1.50 & 1.00 & .75 \\
\hline Brandywine (Per.)........... & 6.00 & 6.00 & 6.00 & 6.00 & 3.75 & 1.50 & 1.00 & .75 \\
\hline & 6.00 & 6.00 & 6.00 & 6.00 & 3.75 & 1.50 & 1.00 & .75 \\
\hline Haverland (Imp.)..... & 6.00 & 6.00 & 6.00 & 6.00 & 3.75 & 1.50 & 1.00 & .75 \\
\hline Gandy (Per.) .................... & 6.00 & 6.00 & 6.00 & 6.00 & 3.75 & 1.50 & 1.00 & .75 \\
\hline Aroma (Per.)... & 6.00 & 6.00 & 6.00 & 6.00 & 3.75 & 1.50 & 1.00 & .75 \\
\hline
\end{tabular}

100 NEVER-STOP PLANTS (Per.). Our Great Everbearing Strawberry-value $\$ 3.00-$ and 100 spring-bearing plants of the huge giant varieties, all grown specially for garden planting and selected to suit your locality-value $\$ 3.00$. Both lots, value $\$ 6.00$, for $\$ 5.00$, delivered free with Plant-Food and Book.

\section{GIANT (Per.)}

Under this head we class several varieties of enormous size and will send you the one best suited to your locality. $\$ 1.00$ for $25, \$ 1.75$ for $50, \$ 3.00$ per 100 .

MASTODON. This season we have grown Mastodon rather extensively on our own grounds, and can recommend them. The fruit is of very large size and a good waxy appearance. Plants are large and healthy, foliage deep, glossy, black green. Produces an abundance of fruit, continuing throughout the summer and fall. $\$ 1.00$ for $25, \$ 1.75$ for $50, \$ 3.00$ per 100 .

Varieties of Strawberry plants marked (lmp.) have imperfect or pistillate blooms and should have every fourth row of the field planted in a (Per.) perfect or staminate blooming kind.

When to Plant.-In the southern and central parts of the country they can be set any time during the fall, winter or spring, that the ground is not actually frozen or miry, the earlier the better; at the North in fall or early spring. Plants shipped September is to April 15, or later, according to season.

We advise that you have all shipments of 500 plants or less sent by parcel post. 'They make quicker time, are delivered by mail carrier, and save you the time of going to express office for the shipment. When rates are nearly the same we will ship by parcel post if we think it to your best adrantage, C. O. D. for amount of charges. If you do not wish this done, and if you prefer express shipment, so state on order sheet.

\section{GIANT STRAWBERRIES A PERFECT PICTURE}

I ordered from you 100 Giant Strawberry Plants. They have done extremely well in consideration of the seasons and are now perfectly full of a nice crop of beautiful large fruit. They are such a beautiful red color and so nice, large and smooth, and have so much fruit on them that every one who sees them just marvels at them and immediately wants some of the plants. As beautiful as my Giants are and as full cif fruit as they are, I indeed wish that you could see them. 'They are a perfect picture. I believe they are the very berry suited to this locality.

Walker Harris, Kathleen, Fla. Jan. 27, 1931. 
Price List-Fall and Winter 1931-32

\begin{tabular}{l}
\hline VARIETIES \\
\hline APPLE-Dixie, Early Colton, Ellis' Everbear- \\
ing, Summer Ambrosia, Hunt's Everbear- \\
ing, Fall Ambrosia (pages 5, 18, 19, 20, 21) \\
All other Apple trees, except the six kinds \\
above
\end{tabular}

PEACH-Neva-Myss, Four-in-One, Ambrosia, Wine, Niagara (pages $3,13,14,15,16,17$ ) Ellis' November (page 15)

All other Peach trees, except the six kinds above

JAPAN PLUM (page 23)

APRICOT (page 24)

MULBERRY, Everbearing (page 23)

CHERRY (page 24)

PEAR (pages 5, 22)

PECAN-Large paper-shell, 4 to $5 \mathrm{ft}$. (pages o 25,26 )

Large paper-shell 5 to $6 \mathrm{ft}$.

SHADE TREES-(See Pages 41,42 )

Maple, Sugar (page 41)

Maple, Norway (page 41)

Maple, Silver (page 41)

Extra-large (page 41)

Lombardy and Carolina Poplar, Elm and Weeping Willow (see page 41 for prices)

UMBRELLA TREES-First-class (page 42)

Very large, extra selected

CATAIPA BUNGEI (see page 42)

EVERGREENS-American a nd Pyramidal

Arborvitae, Norway Spruce (pages 37, 38)

EVERGREEN HEDGE PLANTS - Amoor

River Privet; large

Extra fine plants (page 36)

California Privet

ORNAMENTAL SHRUBS to beautify lawns

द्व (pages $31,32,33,34,35$ for prices)

2 ROSE BUSHES (pages 45, 46, 47, 48, 49)

GRAPE-VINES-Scuppernong and James

Concord, Delaware, Moore's Early, Niagara (pages 27, 28)

FIG BUSHES (page 26)

ASPARAGUS ROOTS (page 28)

RHUBARB (page 26)

HORSERADISH (page 28)

CABBAGE PLANTS (see page 30 for prices)

DEWBERRY AND BLACKBERRY PLANTS (page 29)

RASPBERRY PLANTS (p. 29) Ord. varieties Everbearing (pages 5, 29)

\begin{tabular}{|c|c|c|c|c|}
\hline 100 & 50 & 25 & Dozen & E'ach \\
\hline$\$ 4000$ & $\$ 22 \quad 50$ & $\$ 1200$ & $\$ 600$ & $\$ \begin{array}{lll}\$ & 0\end{array}$ \\
\hline 2000 & 1200 & 700 & $\begin{array}{ll}4 & 00\end{array}$ & 45 \\
\hline 3000 & 2000 & 1200 & $\begin{array}{ll}6 & 00\end{array}$ & 60 \\
\hline $45 \quad 00$ & 2500 & 1400 & $\begin{array}{ll}7 & 50\end{array}$ & 75 \\
\hline 1750 & 1250 & 700 & $\begin{array}{ll}3 & 60\end{array}$ & 40 \\
\hline & & 1200 & 750 & 75 \\
\hline & 20.00 & 1250 & $\begin{array}{ll}6 & 0\end{array}$ & 60 \\
\hline & & & $\begin{array}{ll}9 & 00\end{array}$ & 100 \\
\hline 4500 & 2500 & $14 \quad 00$ & $\begin{array}{r}750 \\
1250\end{array}$ & 125 \\
\hline & & & 1800 & 175 \\
\hline & & & & 300 \\
\hline & & & & 350 \\
\hline & & & & 125 \\
\hline & & & & 150 \\
\hline & & & & 100 \\
\hline & $\ldots$ & & & 150 \\
\hline & & & & \\
\hline & See & Pages & 37,38 & and 39 \\
\hline 800 & 450 & 250 & 150 & 25 \\
\hline 1000 & $\begin{array}{ll}5 & 50\end{array}$ & 325 & 200 & 35 \\
\hline 800 & 450 & 250 & 150 & 25 \\
\hline & & & 750 & 75 \\
\hline 3000 & & $\ldots$ & 500 & 50 \\
\hline 1500 & $\begin{array}{ll}9 & 50\end{array}$ & 550 & $\begin{array}{ll}300 \\
0\end{array}$ & 30 \\
\hline & & .800 & 450 & 50 \\
\hline 250 & 150 & 100 & 50 & ........ \\
\hline & & & 50 & \\
\hline 60 & 400 & 250 & 175 & \\
\hline 60 & 40 & 2 & 175 & \\
\hline $\begin{array}{ll}6 & 0\end{array}$ & 400 & 250 & 175 & \\
\hline
\end{tabular}

\section{WHAT WE DELIVER FREE}

For the very choicest varieties of peach and apple trees, strawberry, raspberry and violet plants and rose bushes, all delivered free with briok and plant-food, see pages 3, 4, 5, $13,14,15,20,35$, and 45 . Only these collections are delivered free.

Doing a mail order business altogether, our stock of trees, plants, etc., is full and is strictly first-class. In fact, we sell under an absolute guarantee, as you will see by referring to page 35 .

We make special prices to large planters of fruit trees. If in the market send us your list of wants, and we will quote you attractive prices. Quality considered, we meet competition from anywhere.

All orders for trees for less than $\$ 1$ must include 25 cents extra to cover actual cost of packing. All larger tree orders and all other orders packed free.

To Make Suie of Getting Just What You Want it is always best to send in your order as soon as you receive this catalogue. First-class stock will then be reserved for you and shipped when directed.

Time of shipment of fruit trees, shade trees, hedge plants, rose bushes, grapevines, etc., from October 15 to April 15. Plant in fall, winter or early spring, no matter how cold, if the ground is not frozen or muddy.

Write for special prices on peach trees and strawberry plants in large quantities. 


\section{Roses}

\section{Large, Hardy, Two-Year-Old Field-Grown Rose Bushes That Go Right Off to Blooming First Year}

\section{(See Cover Page 51 for Pictures of Our Roses)}

12 LARGE, HARDY, TWO-YEAR-OLD, FIELD-GROWN ROSE BUSHES that go right off to blooming first year, Rose Plant-Food for two years, and 100-page book, "Modern Methods in Fruit, Plant and Tree-Growing." ALL DELIVERED FREE FOR \$7.50. Every plant insured.

You must not expect our rose bushes to come to you green and delicate like hothouse plants. Uurs are hardened in the open air and are as vigorous as trees.

In the following list will be found the queens of rosedom, varieties selected for their surpassing beauty and for their vigor in producing abundant flowers.

This collection is made up of the very cream of varieties, assorted colors, white, red, pink, cream and yellows.

Every plant is especially selected and pruned in rocit and branch, to perfect balance for quick and big results. Remember that we send plant-food to make quick growth and quick superb blooms.

\section{Yellow Roses}

Alexander Hill Gray. Largest pure yellow. 75 cents each.

Blumenschmidt. Rich lemon-yellow, often tinged pink. 75 cents each.

Etolle de Lyon. Deep golden gellow. A double Rose. A mag nificent bloomer. 75 cents each.

Lady Hillingdon. Deep golden yellow; superb. 75 cents each.

Helen Good. The color is a delicate yellow, suffuses with pink, each petal edges deeper; very chaste and beautiful. The color with its immense size and exquisite form, makes it without question the great est Tea Rose ever intro duced. A genuine Cochet. 75 cents each.

Madame Francisca Kru ger. A very deep yellow Rose; strikingly handsome. 75 cents each.

Madame Jenny Gillemot. 75 cents each.

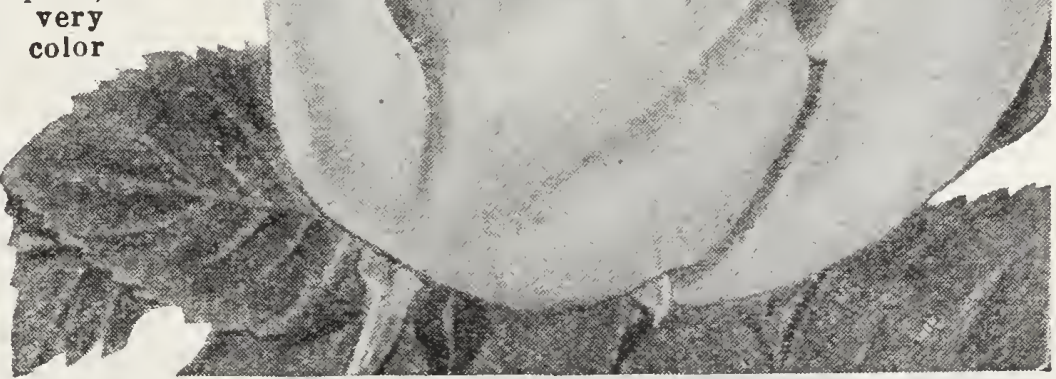

Hugonis. Single, yellow and fragrant. A natural species. ('I'he Golden Rose of China.) $\$ 1.00$ each.

\section{Pink Roses}

Annie Laurie. Sport of Ophelia. Bud large, long-pointed; flower large, cupped, very double (forty petals), very lasting; flesh pink; edges deeper, golden yellow base. Borne on long stem: disease resistant. Few thorns. Very vigorous, upright, bushy. Profuse and continuous bloomer. 75 cents each.

Bridesmaid. A fine, deep pink Rose, interesting for its great beauty as well as its sentimental name. 75 cents each.

F. R. Patzer. Creamy-buff, reverse delicate pink; extra fine. 75 cents each.

Lady Ursula. Color a most beautiful shade of flesh-pink of great substance and good form. 75 cents each.

\section{ROSES FINEST EVER SAW}

The rose 1 ordered from you last year was the finest I ever saw. It had at least one hundred or more buds on it this year. J. L. Rimer, Spencer, N. C.

\section{HIGHLY PLEASED WITH ROSES}

Last August I took advantage of your offer of 12 rose bushes for $\$ 7.50$. They were sent in November at proper planting time. I took sspecial notice of not only their healthy, hardy appearance, but also of the way they were packed-without the roots doubled or crushed. Out of the many, many plant catalogues at my disposal, I am sending my order to your Company because of my past success with your plants and because of your very inclusive guarantee.

I failed to say that my roses are doing well and living in spite of such a severe winter of alternate freezing and thawing. They have a very light protection only. Mrs. J. A. Mullins, Grundy, Va. 


\section{(PINR ROSES-Continued)}

La France. This is claimed by many to be the queen of all the Roses; bright silvery. pink. 75 cents each.

Maman Cochet (The Queen of all Garden Roses). Such beauty and exquisite form as is possessed by this variety is well-nigh marvelous, and cannot be seen in any other Rose we know of. The buds are beautiful, large, full and firm and elegantly pointed; as they expand they show great depth and richness, sometimes measuring two and a half inches from base to tip. 75 cents each.

Jonkheer J. L. Mock. This grand Rose is the strongest growing in the Hybrid 'l'ea Class. The blooms, which are produced with the greatest freedom, are carried on stiff and erect stems, and are of the largest size, of perfect formation and highly perfumed. Uolor clear imperial-pink; a glorious flower. 75 cents each.

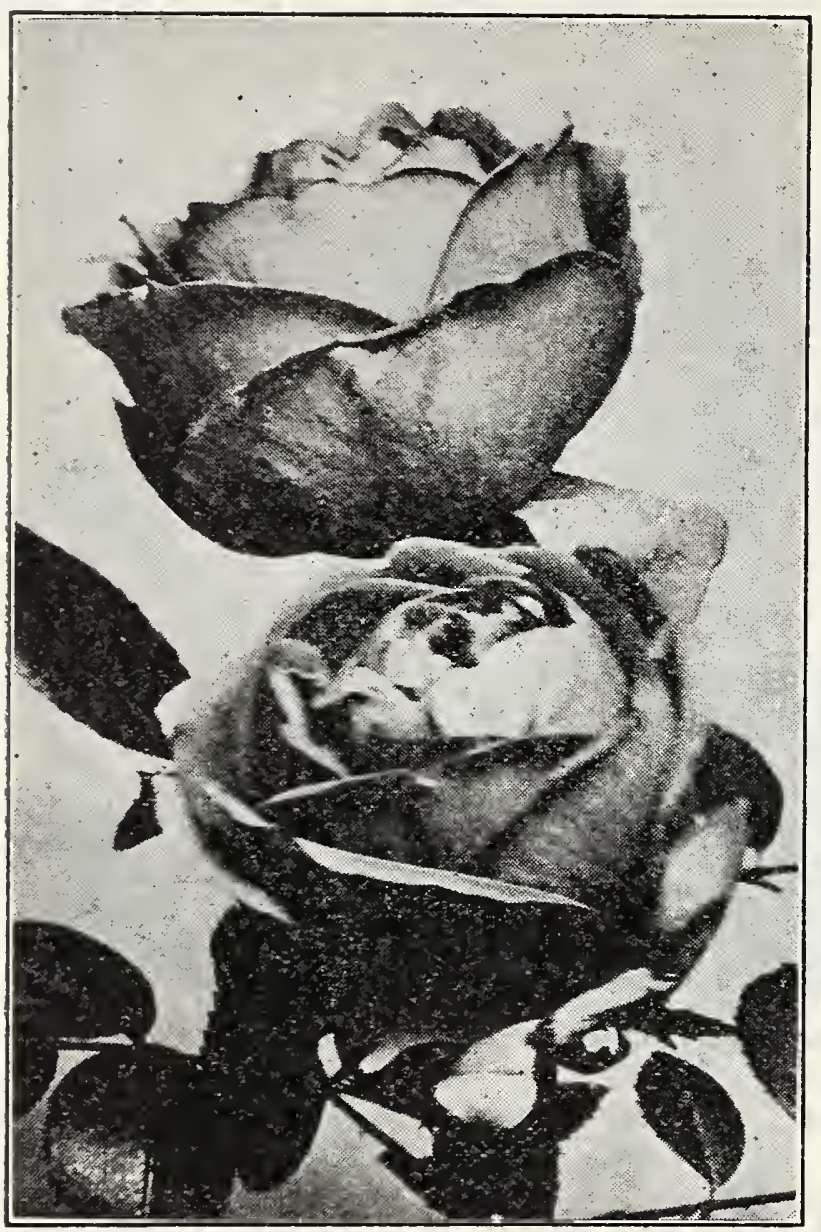

Paul Neyron. Deep Rose or bright pink: large. 75 cents each.

Pink Killarney. Clear rich deep shellpink; a great beauty. 75 cents each.

President Taft. This Rose was raised in Cincinnati, the home of President 'l'aft, and let us say right here, while some of you may not admire the President himself, you will, one and all, admire the Rose given his name. It is without question the most remarkable of all pink roses. 75 cents each.

Los Angeles. One of the grandest allround Roses of American origin ever put on the market. Hlowers large and continuous, in color flame pink, toned with coral and shaded with translucent gold at the base of the petals. $\$ 1.00$ each.

Radiance. A brilliant rosy-carmine, displaying beautiful rich and opaline-pink tints in the open flower. The form is tine, largest size and full, with cupped petals. It blooms constantly and is delightfully fragrant. This is a súperior Rose. $75 \mathrm{c}$.

William R. Smith. Cream color with soft pink shadings. One of the tinest Tea Roses ever grown. 75 cents each.

Wellesley. A beautiful pink, the outside of the petals being very bright in color, with silvery reverse. $75 \mathrm{c}$ each.

Mrs. Charles Bell. It may be described as a shell-pink Radiance, and is a sport of that well-known Rose. It has no characteristics which make it distinct from Radiance except that it is shell-pink. Mrs. Charles Bell, Red Radiance and Radiance offer a range of color that will be welcome, and there are no finer garden Roses for America than these three. 75 cent.s each.

Orleans. Showiest and prettiest of all Baby Ramblers. This charming and dainty Rose is of beautiful rounded habit and is a huge bouquet of deep cerise or Geranium-pink with distinct showy center of pure white; florets not crowded, but of beautiful arrangement, and cannot be beaten. The color is irresistible. Plant, grows like a weed and flowers are nearly "immortelle" in their lasting qualities. 75 cents each.

\section{"Modern Methods" Give You Magnificent Roses the First Year}

What do "Modern Methods" mean! It means making the young rose plants hardy and vigorous by growing in the open and in just the right soil and using just the right rose plant food to give bushes a running start. That's our part. T'hen it means planting right, manuring right, pruning right, cultivating right. That's your part. But our book makes it all plain by not only telling but also showing by practical cuts just how to do it all 


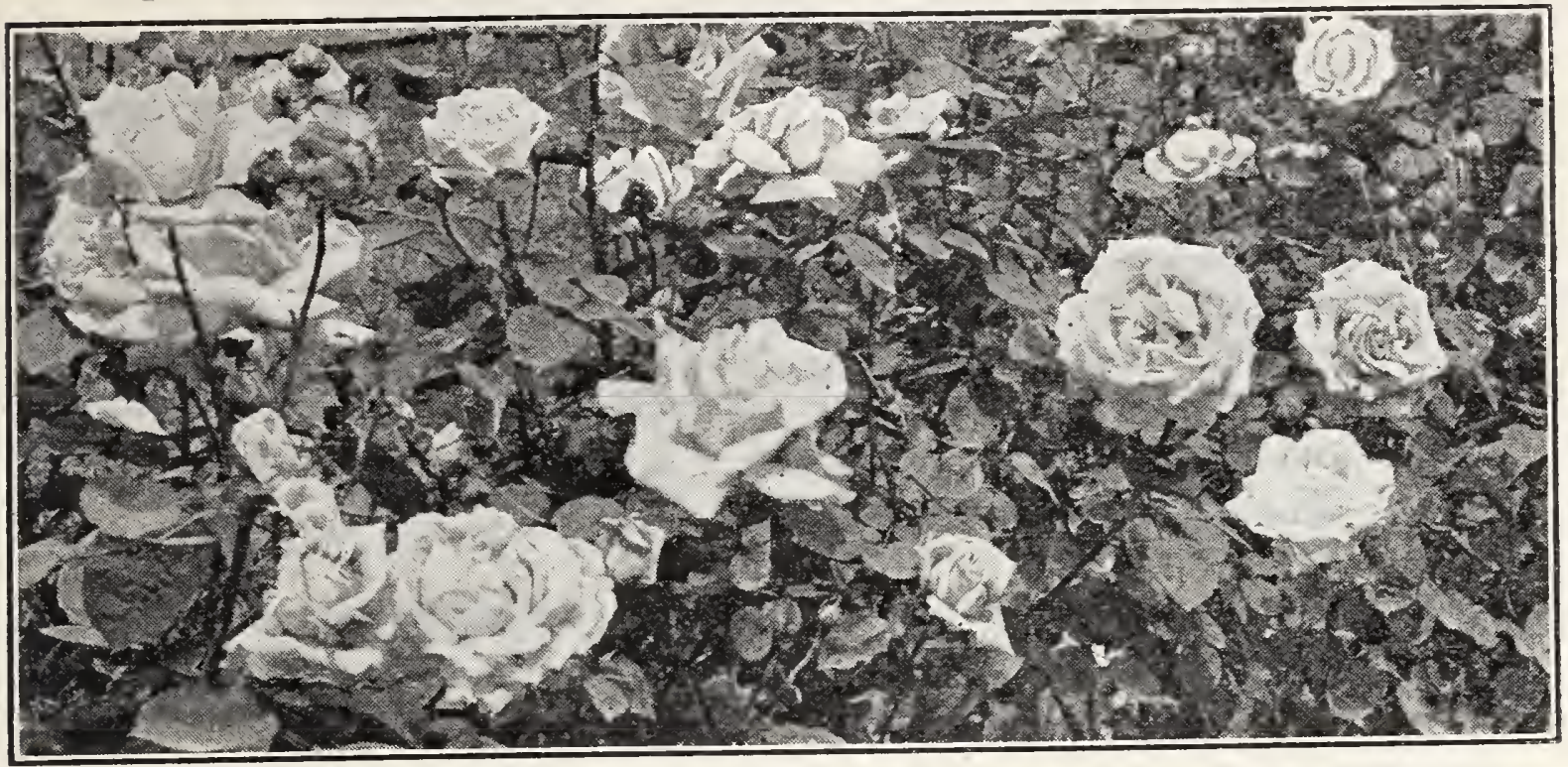

\section{White Roses}

The Bride. Dear to the heart of rose lovers, not only for its sentimental name, but for its own glorious white self. 75 cents each.

Bessie Brown. Creamy-white flowers; sweetly scented. 75 cents each.

Frau Karl Druschki (or White American Beauty). This grand white Rose has become renowned as the very highest type of its class and the best snow white Rose ever introduced. It is an extraordinarily strong grower, and has the vigor and hardiness of an oak. Its magnificent flowers are nothing less than glorious-immense in size and produced with great nificent fow without tinge of yellow or any other shade. A true paper-white, the standard by which all white Roses are judged. 75 cents each.

Kaiserin Augusta Victoria. A grand white garden Rose that has stcod the test of time. Full and double, fine buds and flowers. 75 cents each.

Marie Guillot. Pure white, with large buds and open Howers that are perfect as a Camellia bloom. 75 cents each.

White Killarney. A pure white Rose producing beautiful flowers in great profusion. 75 cents each.

White La France. Pure white with shadings of fawn. 75 cents each.

White Maman Cochet (No finer Rose than this). This rose attracted our attention from the very first time we ever saw it in flower. It is of the largest size, and, as you will notice, the flower is built up or rounded and very double. The color is a pure snow-white. Sometimes out of doors it is tinged pink, which only adds to iis great beauty. No rose survasses it in vigorous growth and in the immense size of its buds and tlowers-indeed, nothing in the Tea family approaclies it in size. Deliciously fragrant. 75 cents each.

\section{Red Roses}

J. B. Clark. The color is unique among roses, being deep scarlet shaded blackishcrimson. with rich bloom like a plum; flowers are large and beautifully formed. Awarded the gold medal N. R. S. 75 cents each.

Charles K. Douglas. Bud large, long pointed; flower large, full double, sweet fragrance; color, intense flaming scarlet, clushed bright velvety crimson. Foliage dark green; disease resistant; vigorous, upright grower; produces an abundance of blcoms from June to October. 75 cents each.

Eugene E. Marlitt. Flower large and double; of a bright carmine with scarlet tones. 75 cents each.

\section{ROSES MOST PERFECT EVER HAD OR SEEN}

Inclosed find check for \$14.57. We have frequently ordered berry plants and fruit trees from you, all satisfactory; but 1 want to tell rou, your roses are the most perfect I have erer had or seen. Being both beau. tiful and hardy. Mrs. A. Gibbs, Thompsons, Tenn.

\section{ROSES MOST GORGEOUS EVER SAW}

I wish you could have seen the 12 twoyear-old roses that I bought of you tive years ago. In August and September they were a picture to lock at. 'They were the most gorgeous roses I ever saw and so many of them. J. L. Taylor, Roanoke, Va. 


\section{(RED ROSES-Continued)}

Francis Scott Key. It is a heavy double rose of great substance. In color red. 75c each.

F. J. Grootendorst. Bud small, double, borne in clusters on average length stems; very lasting; slight fragrance. Color bright red, edges of petals serrated like a carnation. Very hardy. 75 cents each.

Gruss An Teplitz. Bright crimson, white firery•red centers; cup shaped; semi-double; flowers in clusters, presents a blaze of scarlet. 75 cents each.

Gen. Jacqueminot. Known as "General Jack;' shining crimson. 75 cents each.

General Washington. An old favorite; crimson red; large full tlat form; a profuse bloomer. 75 cents each.

Helen Gould. A grand Rose of highest merit; bright watermelon red; very free grower and bloomer. 75 cents each.

Meteor. Vivid, glowing crimson, with a velvety texture. A truly magniticent Rose and a free and constant bloomer. 75 cents each.

Mrs. Benjamin R. Cant. Color deep rose; inner petals soft silvery-rose sulfused with buff at the base. 75 cents each.

Niles Cochet. (The True Red Cochet). Red changing to deep rose. 75 cents each.

Papa Gontier. Rosy-crimson; fine long bud. 75 cents each.

Red Radiance. All who know that grand Rose Radiance will welcome this red form of that great favorite. Radiance is a Rose that does well everywhere; a fine grower and free bloomer, and no prettier pink Rose grown. Red Radiance is its exact counterpart except that the color is a rich deep red. 75 cents each.

Rhea Reid. Flower large and double; rich dark velvety red. 75 cents each.

Therese Zeimet-Lambert. Type, Killarney. Bud large, long-pointed; flower large, full, double, high-centered; deep rose with yellow ground, orange base, borne singly, on long stem; strong fragrance. 75 cents each.

Ideal (Baby Rambler). Flower medium size, double, full, open, globular, dark velvety crimson; very lasting; borne in clusters on average stem; blooms abundantly all season. Hardy. 75 cents each.

\section{Climbing Roses}

American Pillar. Unusually large, single flowers, often 3 to 4 inches across, borne in immense clusters. The color is a delicate pink, with white eye and yellow stamens. 60c each.

Climbing Malmaison. Creamy-flesh; peach-pink center. 60 cents each.

Clothilde Soupert. Ivory-white; center deep silvery-rose. 60 cents eac'a.

Climbing American Beauty. Same color, size and fragrance as American Beauty, with the addition of the climbing habit. Good foliage and better blooming qualities. Blooms three to four inches across; has proved perfectly hardy and stands heat and drought as well as any Rose in our collection. 75 cents each.

\section{OUR ROSES CAUSE SENSATION}

The Climbing American Beauty you sold me last year is causing a sensation. Hundreds of cars pass daily to see this rose arbor of mine, and many stop to ask the name of the rose and where I bought it; others ask me for cuttings. 1 gave your name to at least twenty-five people, if not more.

Miss Marie M. Corvette, Columbia, S. C.

\section{WHOLE COMMUNITY ENJOYS OUR ROSES}

Have bought roses of your nursery before. I have a White La F'rance which is the most wonderful rose. With special care and location, have gathered several hundred roses from it this season. The whole community has enjoyed them, and that is why I am repeating the order.

Mrs. B. G. Early, Elizaville, Ky. 


\section{(CLIMBING ROSES-Continued)}

Climbing Kaiserin Augusta Victoria (Mrs. Robert Peary). Ivory white; elegant. $75 \mathrm{c}$ a.

Climbing Meteor. A grand climber, color velvety maroon. 75 cents each.

Crimson Rambler. A rampant grower; profuse bloomer of flaming red blooms. $60 \mathrm{c}$ each.

Dr. W. Van Fleet. Flowers when open run four inches and over in diameter. 'I'he center is built high, petals beautifully undulated and cupped. 'l'he color is a remarkable delicate shade of flesh-pink on the outer surface, deepening to rosy-flesh in center. $75 \mathrm{c}$ each.

Excelsa. Flowers are very double produced in large trusses of 30 or 40 . Color is intense erimson-maroon. The finest of all red climbing roses. Price $60 \mathrm{c}$ each.

Lady Gay. One of the most magnificent of all pink climbing Roses. $60 \mathrm{c}$ each.

Lamarque. Pure white; very double; an old standby. $75 \mathrm{c}$ each.

Marechal Niel. All in all, this is the most popular of all Roses, as it is the most refinedly beautiful. Blooms an indescribable tint of yellow that is most beautiful and graceful; climbing vines are no less so. Verily, all in all a poem in Roses. $\$ 1.00$ each.

Reine Marie Henriette. Deep cherry-red; a leading climber. 75c each.

Red Dorothy Perkins. Color is intense crimson-maroon. 'I'he finest of all Crimson Ramblers. $60 \mathrm{c}$ each.

Silver Moon. Flowers very large, four and one-half inches and over in diameter. Pure white in culor; petals of great substance, beautifully cupped, forming a clematis-like Hower. The large bunch of yellow stamens in the center adds to its attractiveness. $60 \mathrm{c}$ each.

climbing Columbia. The counterpart of Columbia except a vigorous climber. Bright pink. 75 cents each.

Shower of Gold. The color is a deep golden-yellow with orange shadings in the center. This fills the "long felt want" for a "Yellow Rambler." 75 cents each.

Climbing Red Radiance. Exactly like the bush variety of the same name, except that it is of climbing habit. 75 cents each.

Mary Wallace (A Great Breeder's Legacy). This is Dr. Van F'leet's masterpiece. The trade is slow in taking hold of this charming pillar rose. Hardy, on a line with Washington, D. C. Blooms two or three times during the summer months. A pillar rose supporting itself in a bushy growth 6 to 8 feet high. Bright clear rose-pink with salmon at base of petals. The largest Hybrid Wichuraiana in existence. 75 cents each.

Paul's Scarlet Climber. Vivid scarlet, shaded crimson, makes a brilliant display for a long period of time in the garden. A wonderful climbing' rose. 'We consider it the most wonderful hardy Climbing Rose. 75 cents each.

\section{ROSES BEYOND EXPECTATION}

The roses arrived promptly, in good condition. Fine looking plants, much beyond my expectation. G. C. Stuart, M. D., Eastover, S. C. Dec. 9, 1930.

\section{NICEST ROSES EVER RECEIVED}

The roses came Saturday in fine order. Have been busy all day (Monday) setting them out. They are so lovely and so healthy looking that I am very proud of them, for I feel sure that they will live. They are the nicest order of roses I ever received and I appreciate them. Mrs. A. J. Ervin, Jr., Crawford, Miss.

\section{ROSES ARE EXCELLENT}

Rose bushes received and are excellent. I thank you for filling the order so well. Miss Lula Stewart, Washington, D. C. Nov. 10, 1930.

\section{HIGHLY PLEASED WITH OUR STOCK}

The roses received $O$. K. and were in fine shape and I am more than pleased with them. Our transactions have been $t o m y$ entire satisfaction and I wish to thank you for your courteous consideration. You may expect some future orders from me.

Walter L. Pruitt, Starr, S. C. March 13, 1931.

\section{PLANTS RECEIVED IN FINE CONDITION}

I received your plants in fine condition and am very much pleased with them. The next time I need anything in your line I will be sure to order from you. Wishing you continued success, I remain, K. B. Glass, Lynchburg, Va. Oct. 29, 1930. 


\title{
INDEX--Where to Find What You Want
}

\author{
See Pages 43 and 44 for Price List
}

PAGES

Strawberry Plants. All leading market and table kinds ............... 9 to 11 Never-Stop, the Great Ever-Bearing Strawberry .................. 3 and 6

Peach Trees-Neva-Myss. Earliest of all peaches and only kind that never missed a

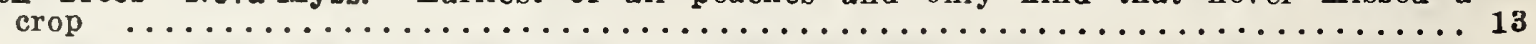

Also all highest, improved peaches, ripening May to November ... 14, 15, 16, and 17

Plum Trees (The glorious Japanese varieties) $\ldots \ldots \ldots \ldots \ldots \ldots \ldots \ldots \ldots \ldots \ldots \ldots \ldots$

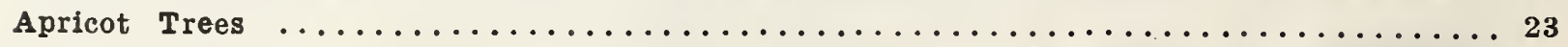

Apple Tres $\ldots \ldots \ldots \ldots \ldots \ldots \ldots \ldots \ldots \ldots \ldots \ldots \ldots \ldots \ldots \ldots \ldots \ldots \ldots \ldots$ 18, 19, 20, and 21

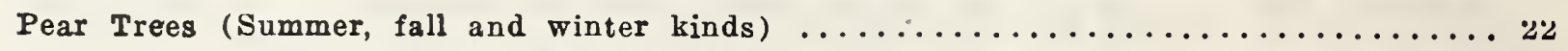

Cherry Trees (Combination fruit and shade) $\ldots \ldots \ldots \ldots \ldots \ldots \ldots \ldots \ldots \ldots \ldots \ldots \ldots \ldots \ldots$

Pecan Trees (Big paper shell kinds). Shade trees and money makers.......25 and 26

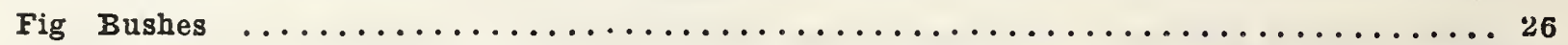

Grape Vines. Leading Bunch Grapes. Also famous Scuppernong and James Grape, 27 and 28 Aspäragus Roots ................................... 28

Raspberry, Dewberry and Blackberry Plants ......................29

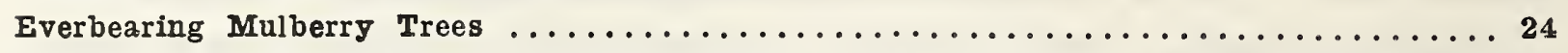

Ever Green Hedge Plants. A perfect evergreen hedge first year, solid as a brick wall,

Rose Bushes. All the most highly improved magnificent kinds. Two-year-old field-grown bushes, with our special Rose plant food and book (both free); (will bloom tirst year) $\ldots \ldots \ldots \ldots \ldots \ldots \ldots \ldots \ldots \ldots \ldots \ldots \ldots \ldots \ldots \ldots \ldots \ldots, 45,46,47,48$, and 49

\section{SHADE TREES}

Quick-Growing Umbrella Trees. Magnificent trees in 3 to 4 years ............42

Catalpa Bungii. A beautiful ornamental tree $\ldots \ldots \ldots \ldots \ldots \ldots \ldots \ldots \ldots \ldots \ldots \ldots \ldots$

Sugar, Norway and Silver Maple, Lombardy and Carolina Poplar, Elm and Weeping

Willow $\ldots \ldots \ldots \ldots \ldots \ldots \ldots \ldots \ldots \ldots \ldots \ldots \ldots \ldots \ldots \ldots \ldots \ldots \ldots \ldots \ldots \ldots . \ldots \ldots$

Evergreens $\ldots \ldots \ldots \ldots \ldots \ldots \ldots \ldots \ldots \ldots \ldots \ldots \ldots \ldots \ldots \ldots \ldots \ldots \ldots \ldots$ 37, 38, 39, and 40

Ornamental shrubs ......................... 31; 32, 33, 34, and 35

Frost-Proof Cabbage Plants (Head far earlier than other kinds because they can be

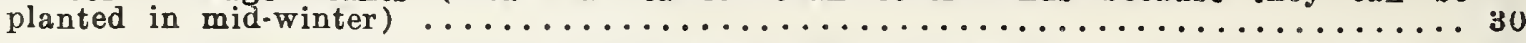

Fruit Tree and Plant Food, which hastens growth and fruiting and greatly increases the yield, free with certain collections of trees and plants ..................

Modern Method Fruit Tree and Plant Book-Tells and shows by plain pictures how to grow every thing; how to plant, manure and prune fruit trees; how to grow a perfect hedge and splendid roses first year; shade trees in three years, etc. ........ 12

\section{DELIVERED FREE}

Only Choice Collections of Fruit Trees, Strawberry and Raspberry Plants, Rose Bushes, Etc. With plant food and book. See pages...... 3,4,5,13,14, 15, 20, 35, and 45

\section{- our guarantee}

Every tree, plant, shrub, bush, etc., offered by us is strictly first class and is guaranteed to satisfy the purchaser. Note the broad guarantee given on page 35 . It is, we believe, the broadest guarantee given by any nursery in the country.

Bundle of trees shipped me on the 10 th inst. were received promptly and have been planted. I wish to express my entire satisfaction with the manner in which they were shipped, their looks and their state of health when they were unpacked and the future prospects I see in them. I also received the book and followed the instructions therein when planting. Thanking you for your kindnesses, I am

Mrs. Olive P. Hinman, Warsaw, N. C. Nov., 1930. 


\section{$99^{\text {th }}$ Semi-Annulall Caltallogule of}
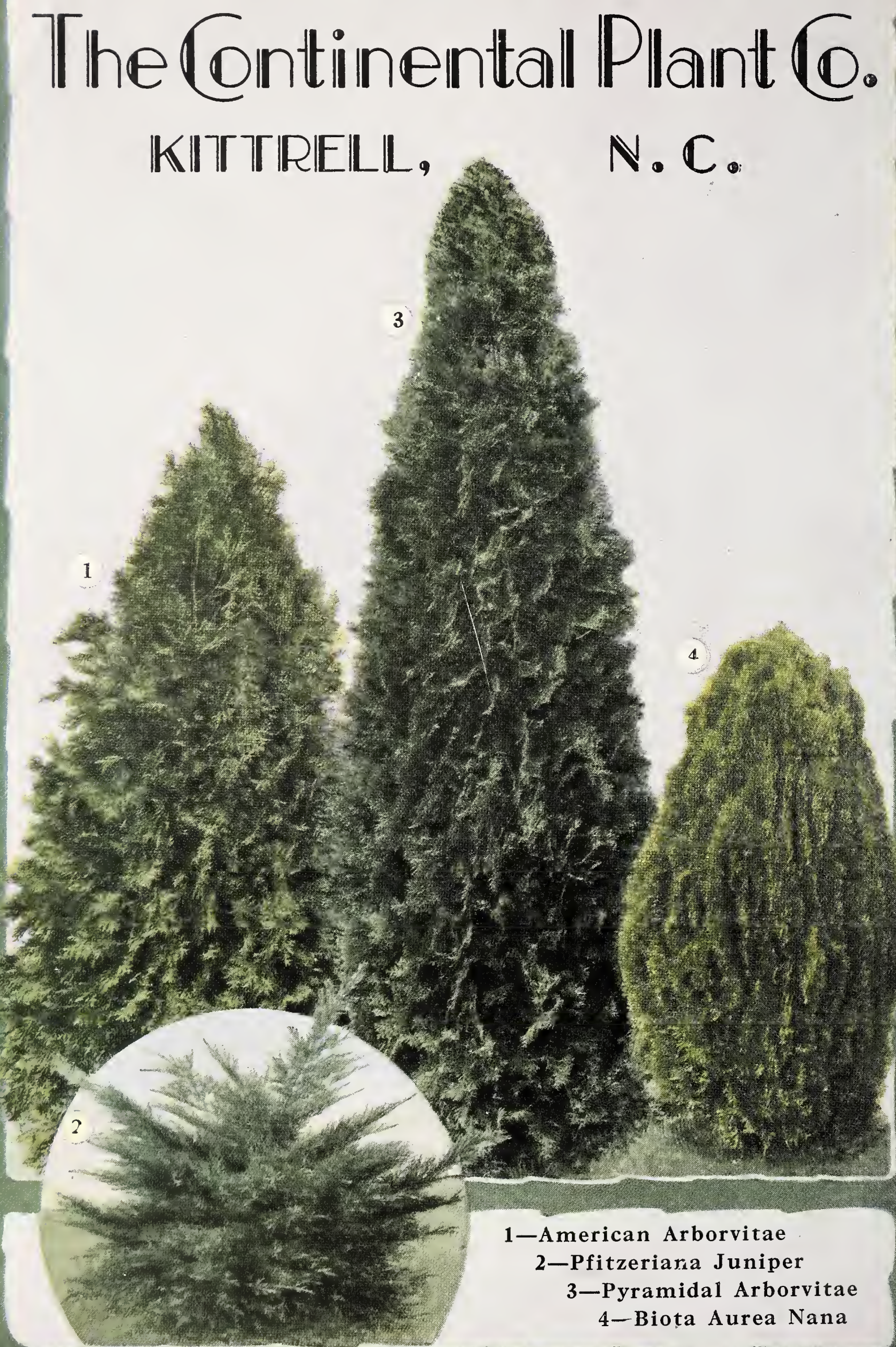